UNIVERSIDADE DE SÃO PAULO

FACULDADE DE FILOSOFIA, LETRAS E CIÊNCIAS HUMANAS DEPARTAMENTO DE HISTÓRIA

\title{
OS ARQUIVOS DA ADMINISTRAÇÃO PÚBLICA NOS MUNICÍPIOS DO GRANDE ABC PAULISTA - A BUSCA DO FIO DE ARIADNE
}

Maria de Lourdes Ferreira

Dissertação apresentada ao Programa de Pós Graduação em História Social da Faculdade de Filosofia, Letras e Ciências Humanas da Universidade de São Paulo, como exigência parcial para obtenção do título de Mestre.

Orientador: Prof ${ }^{\mathrm{a}}$ Dr$^{\mathrm{a}}$ Heloísa Liberalli Bellotto 


\section{UNIVERSIDADE DE SÃO PAULO FACULDADE DE FILOSOFIA, LETRAS E CIÊNCIAS HUMANAS DEPARTAMENTO DE HISTÓRIA}

OS ARQUIVOS DA ADMINISTRAÇÃO PÚBLICA NOS MUNICÍPIOS DO GRANDE ABC PAULISTA A BUSCA DO FIO DE ARIADNE

Maria de Lourdes Ferreira 


\section{SUMÁRIO}

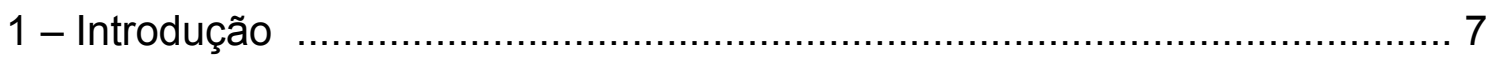

2 - A região do Grande $A B C$ - das origens à reintegração …........................... 14

3 - As administrações públicas municipais no $A B C$ e seus arquivos -

O Minotauro e seu Labirinto

3.1 - O Município e os Arquivos Municipais ………….......................... 31

3.2 - Documentos públicos e sua custódia no ABC paulista .................. 48

4 - Iniciativas de gestão documental: a tarefa de Sísifo

4.1 - Arquivo público - identificação e coordenadas contemporâneas

4.2 - Duas experiências pragmáticas de gestão documental no $A B C$

4.2.1 - Avaliação documental 82

4.2.2 - Microfilmagem de documentos

4.2.3 - O equívoco da interdependência entre avaliação e microfilmagem

5 - Avaliação documental: principais abordagens teóricas e metodológicas

5.1 - Conceituação 129

5.2 - Avaliação como função arquivística - histórico 132

5.3 - Principais abordagens teóricas e metodológicas 143

6 - Uma política pública de arquivos na região do $A B C$ - a busca do Fio de Ariadne

6.1 - Políticas públicas e políticas públicas arquivísticas 156

6.2 - Instituição de uma política pública de arquivos no ABC 159

7 - Considerações Finais 163

Bibliografia 168

Anexos 
Resumo: Este trabalho busca investigar as políticas e práticas das administrações públicas dos municípios do Grande $A B C$ paulista quanto a seus documentos de arquivo. Procura identificar quem detém sua custódia, e quais as ações destas administrações quanto a seu controle, mais especificamente os processos pragmáticos de avaliação e microfilmagem documental, tendo como contraponto a teoria arquivística. A região estudada compreende os municípios de Santo André, São Bernardo do Campo, São Caetano do Sul, Diadema, Mauá, Ribeirão Pires e Rio Grande da Serra. Considerando as experiências de ação integrada que têm se verificado na região a partir da constituição de organismos supramunicipais como o Consórcio Intermunicipal do Grande ABC, a Câmara do Grande ABC e o Forum da Cidadania, entre outros, aponta as condições e elementos para o estabelecimento de uma política pública de arquivos para a região.

Palavras-chave: Grande ABC, arquivos públicos municipais, avaliação documental, política pública de arquivos.

\begin{abstract}
This paper intends to investigate the policies and actions carried on by public administrations in the metropolitan region of $A B C$, in São Paulo State, concerning its records. It tries to identify who is responsible for the documents custody, how these administrations conduct the control of this material, especially focusing on the pragmatic processes of records evaluation and microfilming, in opposition to archival theories. The studied region is composed by seven cities: Santo André, São Bernardo do Campo, São Caetano do Sul, Diadema, Mauá, Ribeirão Pires, e Rio Grande da Serra. Taking into consideration the experiences of integrated actions that have been implanted in the mentioned region since the constitution of organisms ruled by a group of public administrators from different cities, like the Consórcio Intermunicipal do Grande $A B C$, the Câmara do Grande $A B C$ and the Forum da Cidadania, among others, this paper indicate the conditions and elements to the devellopment of a public policy on archives to the region.
\end{abstract}

Keywords: Metropolitan Region of ABC, public municipal archives, documents appraisal, public policy on archives. 
Às minhas filhas, Sarah e Flávia, que compreenderam o pouco tempo disponível para elas durante a realização deste trabalho, pelo incentivo, colaboração e afeto;

à Ana Maria, irmã e amiga querida, com quem sempre repartí tristezas e alegrias;

à minha mãe, pelos exemplos de perseverança $\mathrm{e}$ coragem, pela confiança e amor infinito. 
Agradecimentos

Este trabalho só foi possível graças a pessoas que, de diversas formas e em diferentes momentos, colaboraram para que fosse realizado:

- os funcionários das instituições de história e memória dos municípios do Grande ABC e das Câmaras e Prefeituras Municipais, pela disponibilidade e atenção;

- a poeta e produtora cultural Dalila Teles Veras, da Livraria Alpharrabio de Santo André, que disponibilizou sua hemeroteca;

- os amigos de todas as horas, Cesar e Viviane, pelo incentivo e colaboração;

- os professores Ana Maria de Almeida Camargo e José Augusto Chaves Guimarães, pelas observações e críticas esclarecedoras durante meu exame de qualificação, sendo que à professora Ana Maria devo ainda a disponibilização de sua biblioteca para pesquisa;

- o fisioterapeuta Rodrigo, do Hospital Estadual Serraria, que muito contribuiu para minha recuperação, possibilitando a conclusão deste;

- e muito especialmente a professora Heloísa, orientadora e mestra, pela sensibilidade, atenção e segurança na condução deste trabalho em todas as suas fases.

A todos sou muito grata. 


\section{1 - Introdução}

$\mathrm{O}$ arquivista norte-americano Theodore Schellenberg, utilizou em suas obras a expressão "arquivos modernos" pelas diferenças em qualidade e quantidade que possuem os arquivos contemporâneos em comparação com os existentes na Idade Média e no início da Idade Moderna. Aumento da população e de suas demandas, ampliação das atividades e funções dos poderes públicos para atendê-las, utilização de novas tecnologias na produção de documentos, são alguns dos fatores para a constituição dos chamados "arquivos modernos". Acrescentamos a estes fatores, a obrigatoriedade que os governos têm de documentar seus atos e prestar contas deles, características dos atuais regimes democráticos. Vivemos a chamada era da "explosão documental" e quando não existe nas organizações uma política de gestão dos documentos, surge o que é conhecido pelos arquivistas como "massa documental acumulada".

$\mathrm{Na}$ introdução de sua dissertação de mestrado, Souza (1995), faz da mesma, uma significativa caracterização,

"é possível encontrar conjuntos arquivísticos que são resultado da transferência dos documentos dos arquivos montados nos setores de trabalho. Esses acervos são denominados, comumente, 'arquivos mortos'. São também identificados por 'arquivo geral" e 'arquivo central'. Acondicionados inadequadamente, acumulam-se em locais igualmente inadequados: subsolos, garagens, porões, corredores, prédios abandonados.

Constituem-se assim as massas documentais acumuladas, onde documentos de valor permanente, misturam-se a documentos de valor intermediário, que podem ser descartados cumpridos seus prazos administrativos ou legais, e documentos elimináveis de imediato, sem 
nenhum valor administrativo, legal, informativo ou histórico. A maior parte destes documentos foram produzidos ou recebidos pelas atividades-meio, predominando os processos administrativos e as correspondências. Os documentos das atividades-fim permanecem nos próprios setores, não são encaminhados para o 'arquivo geral' por não serem considerados documentos de arquivo ou por descrédito do mesmo, graças às condições de guarda dos documentos e recuperação das informações."

O contato com esta realidade, comum a muitos municípios brasileiros, foi determinante para que definíssemos o objeto desta dissertação. Este se deu quando de nossa participação em uma "Comissão de Avaliação de Documentos e Processos" (1998/1999), como funcionária da Prefeitura de Diadema, uma das sete cidades do Grande $A B C$ paulista, uma região com origem, cultura e problemas comuns. À fragmentação que constituiu os sete municípios, contrapõe-se nos últimos anos a busca pela integração, por soluções intermunicipais. De acordo com esta ótica, não nos concentramos em apenas um município, mas, pensando a região procuramos investigar as políticas e práticas das administrações destes municípios com relação a seus documentos públicos, comparando-as.

Concordamos com Lopes (1993) que,

\begin{abstract}
"as massas documentais existem porque os documentos na fase corrente não foram objeto de tratamento técnico científico. Um arquivo ativo que seja organizado de acordo com um plano de classificação de documentos e que tenha o seu ciclo vital determinado por uma tabela de temporalidade não gerará massa documental acumulada."
\end{abstract}

Nas administrações estudadas, os documentos na fase corrente são organizados e acondicionados por oficiais administrativos ou por outros servidores encarregados desta atividade (operacionais em desvio de função, 
jovens que trabalham por um algum período na administração por convênio com alguma instituição ou projeto social) que desempenham esta atividade de acordo com seu próprio critério. Não há um quadro de classificação nem para os documentos das atividades-meio, que constituem o maior volume, nem para os documentos das atividades-fim. Ou mesmo Manuais de Procedimentos, com normas que orientem os funcionários, estabelecendo critérios para as administrações como um todo.

Durante o período de pesquisa e coleta de informações, pudemos constatar também que "não há lugar para os documentos", até mesmo os de uso corrente. A necessidade de colocar um novo equipamento ou funcionário que chega, a mudança para um novo espaço, são motivos para que os documentos sejam descartados. No município de Diadema, por exemplo, vimos Processos de Compras do ano corrente serem enviados para o Arquivo Geral, uma determinação da chefia de serviço para acomodar o novo mobiliário do setor.

A primeira tentativa é enviá-los para o Arquivo Geral ou "arquivomorto" da administração. Se não são aceitos, porque este já não possui espaço ou por falta de disposição dos funcionários deste serviço, já que inexistindo normas claras, vigoram as relações pessoais, são colocados em desvãos, banheiros desativados, etc.

A ausência de gestão documental a partir da produção do documento e de tratamento arquivístico em todas as suas fases, produz o acúmulo desordenado dos mesmos e todas as suas conseqüências. Esta questão só passa a ser objeto de preocupação quando, após vários alertas dos responsáveis por sua guarda, não há mais espaço ou os documentos guardados em condições precárias começam a se perder. Referindo-se a esta situação frequentemente encontrada, os arquivistas espanhóis Alberch Fugueras e Cruz Mundet (1999), assim a caracterizam, 


\begin{abstract}
"é bem comum, infelizmente, que ao deparar pela primeira vez com a tarefa, o que o arquivista adquire antes de mais nada é a responsabilidade sobre $o$ caos precedente. Enquanto outros profissionais assumem tarefas em andamento ou começam do zero, nos arquivos já se começa 'com números vermelhos', pois o que se recebe é a responsabilidade sobre a desorganização, em muitos casos acumulada durante séculos."
\end{abstract}

Entretanto, ainda não é uma política e uma prática nas administrações estudadas que se contrate um profissional da área de arquivos para buscar soluções para estas questões. Mesmo quando isto é sugerido aos gestores (Chefes de Serviço, Diretores, Gerentes), e no decorrer de nosso trabalho colocamos vários exemplos nos diferentes municípios, a opção é utilizar uma solução doméstica, ou o chamado "bom senso". A questão dos arquivos não é vista ainda como uma tarefa com especificidades que demandam um profissional da área para bem desempenhá-la. O que ocorreu em muitos casos foi procurar os municípios da região ou o município de São Paulo, para conhecer as soluções adotadas. Estas visitas, às vezes serviam de consolo, pois viam situações semelhantes ou piores. Ou procurava-se adaptar as disposições legais de outro município a uma realidade diferente, caso das normas para avaliação e destinação de documentos da Prefeitura Municipal de São Paulo, município que possui um Arquivo Histórico Municipal para onde os documentos de caráter permanente podiam ser encaminhados, ao contrário de municípios do Grande ABC.

Por isso este trabalho procura contrapor às soluções pragmáticas buscadas pelas administrações para a questão documental, aquilo que é estabelecido pela teoria arquivística, particularmente no caso da avaliação documental.

Quanto à estrutura do trabalho, no primeiro capítulo traçamos um breve histórico da região, origens, desenvolvimento, desmembramentos, que deram lugar aos atuais municípios de Santo André, São Bernardo do Campo, 
São Caetano do Sul, Diadema, Mauá, Ribeirão Pires e Rio Grande da Serra. Ainda neste capítulo, evidenciamos a grande imbricação que existe entre eles e as tentativas de integração, a partir de sua associação em 1990, no Consórcio Intermunicipal das Bacias do Alto Tamanduateí e Billings, mais conhecido como Consórcio Intermunicipal Grande ABC.

No segundo, tratamos da documentação pública da região do $A B C$. São documentos públicos de arquivo no âmbito municipal, os documentos produzidos e acumulados pelo Poder Executivo e pelo Poder Legislativo. Neste trabalho, optamos por estudar as práticas relativas aos documentos do Poder Executivo.

Iniciamos pela caracterização do município brasileiro, suas peculiaridades, a autonomia, de intensidade variável nas diversas fases de nossa história, realçada na Constituição de 1988, e a concentração de atribuições do município, também ampliada a partir deste momento. $E$ ainda a especial inter-relação que aí se verifica, resultante dos vínculos existentes entre a população, e entre a população e os governos municipais.

Ainda neste ítem, tratamos dos Arquivos Municipais como instituição arquivística pública, e dos marcos legais existentes hoje no Brasil, normalizando a instituição e a gestão de arquivos públicos.

Procuramos identificar os responsáveis pela custódia desses documentos, suas condições de armazenamento e acesso, relacionando os ítens tratados com princípios arquivísticos. Dada a dispersão e fragmentação ocorrida e a inexistência de processos de controle no que respeita à gestão documental, a metáfora do Minotauro e seu Labirinto se aplica a maior parte deles.

O capítulo seguinte trata do Arquivo Público, desde seu conceito original até as coordenadas contemporâneas. Investiga duas iniciativas pragmáticas de gestão documental, verificadas nos municípios de maior porte da região: microfilmagem e avaliação de documentos e a interdependência que se observa entre as mesmas em sua aplicação nestes 
locais. Devido às dificuldades e descontinuidades observadas nas tentativas de solução para a questão da acumulação documental e sua gestão, fizemos referência ao mito de Sísifo, personagem da mitologia grega condenado a uma tarefa que nunca conseguia terminar.

Concluindo o capítulo, tratamos a avaliação como função arquivística, discutindo seu conceito, traçando seu breve histórico, das primeiras iniciativas ao atual estado da questão, detendo-nos na explicitação das idéias mestras sobre avaliação.

Finalmente, o último capítulo retoma a questão regional, ao propor uma política pública de arquivos para a região do $A B C$. Já existem no $A B C$ várias iniciativas no sentido de viabilizar políticas públicas que atendam necessidades comuns, e os capítulos anteriores mostraram que não há tratamento arquivístico na documentação das administrações públicas estudadas. Concordando com Heredia Herrera (1994), que não existe nada mais parecido com um arquivo municipal que outro arquivo municipal devido a semelhança institucional de sua procedência, procuramos analisar as condições e equacionar os pontos fundamentais para o estabelecimento de uma política pública arquivística que, atendendo as necessidades de gestão dos documentos pelas administrações, possa preservar a história destas instituições e o patrimônio documental dos municípios da região, que pode ser considerado um patrimônio comum.

Esta política pública seria o fio de Ariadne.

$\mathrm{Na}$ elaboração deste trabalho recorremos a documentos administrativos, como processos, relatórios, projetos, que estavam nos arquivos centrais dos municípios ou nas instituições de História e Memória da região, museus, centros de documentação e memória, etc. $E$ a documentos institucionais, folders, informativos, etc. Utilizamos a legislação municipal consultada nas bibliotecas das prefeituras e das câmaras municipais. No caso das instituições de História e Memória, e nas bibliotecas citadas (com exceção da biblioteca da Câmara Municipal de São Caetano do Sul) é 
facultado o acesso da documentação ao público. Quanto aos documentos que se encontravam nos arquivos, foi necessário solicitar autorização para consulta e enquanto em alguns foi um trâmite bastante simples, em outros, muitos impedimentos eram colocados para o acesso.

Além da resposta a um questionário de coleta de dados, que serviu inclusive para que pudéssemos contatar os setores de Arquivo e Microfilmagem, os funcionários desses serviços prestaram muitas informações pessoalmente ou por telefone e por e-mail, quando havia necessidade de completar ou confirmar dados.

Quanto a depoimentos de funcionários e gestores responsáveis pelas ações que estudamos, foi pequena a disponibilidade, daí termos poucos relatos e avaliações neste sentido. Entendemos que isto ocorreu por estarem ainda vinculados às administrações e porque como no município as relações são mais próximas, receavam a identificação.

$O$ que se percebe é que o acesso aos documentos dos poderes públicos, e às informações ligadas a eles, ainda não é visto como direito do cidadão e do pesquisador. A polêmica que ocorre atualmente no país sobre os chamados "arquivos da ditadura", é bem ilustrativa disso.

A imprensa local também forneceu algumas informações significativas e "pistas" valiosas.

Quanto à teoria e questões arquivísticas, recorremos aos manuais e outras publicações de estudiosos do assunto, trabalhos acadêmicos, artigos de revistas da área, Anais dos Congressos de Arquivologia. No que respeita à função arquivística da avaliação, a maior parte dos trabalhos é de autores de outros países e muitos foram conseguidos através da internet.

Nossa intenção não foi esgotar estes assuntos, mas estudando-os, chamar a atenção para os mesmos e para o interesse de maiores debates sobre estas questões, pois como afirmam Alberch Fugueras e Cruz Mundet (1999) "o território dos arquivos apesar de ser próximo, não deixa de ser desconhecido". 


\section{2 - A região do Grande $A B C$ - das origens à reintegração}

"Eu sou o Alcaide-mor desta Vila de Santo André da Borda do Campo. Quando cheguei a esta parte do Brasil nenhuma bota de homem branco tinha marcado a areia da praia. Quando o primeiro donatário chegou, eu já tinha umas três famílias. Naturalmente, devo obediência ao Governador Geral desta terra e até mesmo a Sua Majestade El-Rei, lá em seus paços em Lisboa... A contragosto fui levado - digamos suspender temporariamente minhas fidelidades ao Governador Geral e outras autoridades, que, sob a capa de dar maior proteção à comunidade branca do planalto em que nos achamos, pretendem que eu transfira para o Colégio dos Jesuítas em São Paulo os foros de vila e o pelourinho de Santo André da Borda do Campo."

Cidade Assassinada - Antonio Callado

A chamada região do Grande $A B C$, no Estado de São Paulo, é composta por sete municípios - Santo André, São Bernardo do Campo, São Caetano do Sul, Diadema, Mauá, Ribeirão Pires e Rio Grande da Serra, localizados no sudeste da Região Metropolitana da cidade de São Paulo. As zonas urbanas desses municípios estão "conurbadas", praticamente todas ligadas entre si. A população dessas cidades soma 2.449 .03 habitantes ${ }^{1}$, e é também o terceiro mercado do Brasil, só superado pelo Rio de Janeiro e São Paulo.

\footnotetext{
${ }^{1}$ IBGE - Instituto Brasileiro de Geografia e Estatística - Estimativa (2004).
} 
As raízes históricas dessa área estão ligadas aos primórdios da colonização do Brasil. Localizada na borda do Planalto, era cortada por uma trilha que conduzia ao mar. A partir da segunda metade do século XVI este caminho, antes percorrido pelos indígenas, passou a ser utilizado pelos portugueses, preocupados em conquistar, povoar e garantir a posse da terra. Assim o que se conhece hoje por $A B C$ era apenas um ponto de passagem até $\mathrm{O}$ estabelecimento de uns poucos habitantes que formavam uma povoação liderada por João Ramalho.

Em 1553, o Governador Geral Tomé de Souza oficializou a Vila de Santo André, constituindo como seu Alcaide-Mor, João Ramalho. A povoação passou a ter um pelourinho, símbolo do poder e da justiça e começaram as providências para a instalação da Câmara.

Tomé de Souza considerava de grande importância a instalação dessa Vila para a defesa do "campo" contra os ataques de possíveis inimigos, bem como para a conquista do sertão. Mas em 1560, o pelourinho, João Ramalho e os outros moradores da Vila foram transferidos, por determinação do governador Mem de Sá, para São Paulo de Piratininga, povoamento junto ao colégio criado pelos jesuítas em 1554.

As terras da antiga vila passam a constituir o bairro rural da Borda do Campo. Essa denominação abrangia "os territórios depois ocupados pelos municípios de Diadema e Santo André, além de São Bernardo desde a Serra do Mar até Rudge Ramos" (SANTOS, 1992). Quanto à propriedade destas terras, o mesmo autor afirma que "parte considerável da atual região do $A B C$ corresponde à sesmaria de Amador de Medeiros. No século XVI a mesma foi herdada por Miguel Aires Maldonado que as concedeu aos Beneditinos conforme documentação que conservam".

Lentamente a região se povoou, pois eram esparsas as missões estabelecidas pelos jesuítas e as fazendas formadas pelos portugueses e mamelucos. 
A região da Borda do Campo continuava a ser um lugar de passagem entre a povoação de São Paulo e o litoral:

"Partindo-se de São Paulo com destino ao litoral, existem dois caminhos para se chegar à Serra: o Caminho Velho do Mar e o Caminho Novo. O Caminho Velho do Mar principiava na atual Rua do Carmo e descia a várzea para atravessar os lados da Borda do Campo. Além do Anhangabaú saía o Caminho Novo do mar que cruzava a mata do Caaguaçu e ia pela várzea ao Geribatiba." (MARTINS, apud MONTEIRO, 1995).

Viajantes e tropas carregadas de mercadorias na rota Litoral-Planalto Paulista aportavam em alguns raros pousos. No governo do Morgado de Mateus (1765-1775), foram feitas melhorias no antigo caminho, mas o mesmo ainda apresentava muitos obstáculos. A demanda pelo açúcar paulista, a expansão dos canaviais e a determinação do governador Bernardo José de Lorena de que esta mercadoria só podia ser comercializada através do porto de Santos e diretamente para o Reino aumentou o movimento das tropas. Para facilitar o transporte o governador fez construir em 1789-1790, uma nova estrada com calçamento do trecho da serra, que ficou conhecida como Calçada do Lorena (RODRIGUES, 1991).

A presença da Ordem dos Beneditinos na região iniciou uma nova fase, com fazendas que se dedicavam à produção agrícola, à criação de animais e à produção de cerâmica. Juntaram-se aos índios livres e aos índios administrados, portugueses e mamelucos, os negros trazidos para trabalhar nas terras e olarias de propriedade dos monges beneditinos.

Segundo Santos (1992), em 1631 começa a formação da Fazenda Tijucuçu, em terras doadas aos frades beneditinos por Duarte Machado e em 1671, Fernão Dias Pais Leme fez nova doação à Ordem na região do Tijucuçu. A propriedade ficou conhecida como Fazenda São Caetano do Tijucuçu desde 1743. Em 1637, a antiga sesmaria da Borda do Campo de Amador Medeiros foi doada aos beneditinos que fundaram no local uma fazenda e uma capela de invocação a São Bernardo, origem da povoação de 
São Bernardo, mais tarde designada São Bernardo Velho. E a denominação Borda do Campo aos poucos foi sendo substituída por São Bernardo.

No século XVIII aparecem na região algumas capelas, uma referência de seu rarefeito povoamento, "em 1714, no bairro do Caaguaçu (hoje Ribeirão Pires), foi fundada pelo capitão-mor Antonio Correa de Lemos, uma capela em homenagem a Nossa Senhora do Pilar; em 1736, o padre Salvador Pires Santiago, morador de um sítio na Borda do Campo doou terras para a construção de uma capela por invocação de Nossa Senhora da Conceição. Provisionada em 1738 pelo vigário de São Paulo, Mateus Lourenço de Carvalho, a mesma capela foi visitada por ele em 1740. Essa capela ficava a três léguas da capital no bairro Acuri ou Guacuri, depois Vila Conceição, hoje Diadema" (SANTOS, 1992).

O bairro de São Bernardo, que até 1812 integrava a freguesia da Sé, requeria seu desmembramento: seus moradores reivindicavam maior autonomia, pois já possuíam autoridades como policiais das Ordenanças e inspetor da estrada, mas faltava a figura do pároco para que fosse criada uma Freguesia correspondente a esse bairro disperso. Isso ocorreu através do alvará do príncipe regente de 21 de outubro de 1812, registrado no livro Tombo $n^{\circ} .1$ da Catedral de São Paulo.

Como a capela de São Bernardo da fazenda dos beneditinos era particular, pertencia à Ordem, os monges cederam ao vigário da nova paróquia um terreno distante da sede da fazenda para que ali fosse construída nova matriz com outro orago. Com isto houve a mudança do nome da paróquia para Nossa Senhora da Conceição da Boa Viagem. A construção da Igreja Matriz de São Bernardo iniciou-se em 1814 e foi inaugurada em 1825.

$\mathrm{Na}$ segunda metade do século XIX a região se transformou significativamente, com a construção da Ferrovia São Paulo Railway (1865) e a criação dos núcleos coloniais. Também nesta época é inaugurada a estrada do Vergueiro (1863). 
Quanto à criação da ferrovia que visava facilitar o escoamento da produção cafeeira paulista pelo porto de Santos, "o governo imperial oficializou pelo Decreto $\mathrm{n}^{\circ}$. 1759, de 26 de abril de 1956, a concessão por 90 anos ao Marquês de Monte Alegre, Marquês de São Vicente e Barão de Mauá, para construir e explorar uma estrada de ferro que ligasse o porto de Santos às regiões produtoras do café passando por São Paulo" (PINTO, apud MONTEIRO, 1995).

A construção da ferrovia começou em 1860, e como era escasso o povoamento da região, muitos trabalhadores portugueses, espanhóis, italianos e brasileiros vieram trabalhar na mesma.

Já a Estrada do Vergueiro, inaugurada em 1863, cortava toda a Freguesia de São Bernardo, interligando São Paulo, capital, a Santos e na verdade recuperava o antigo Caminho do Mar, ponto de passagem desde o século XVI. Seu nome decorre de seu construtor, José Vergueiro, filho do Senador Vergueiro (SANTOS, 1992).

Um número maior de trabalhadores imigrantes chegou à região com a criação dos núcleos coloniais. Uma política de imigração e substituição da mão de obra escrava já estava em curso. Monteiro (1995), menciona o Decreto-geral nº 3.784 de 19 de janeiro de 1867, do Presidente da Província de São Paulo, que regulava a fundação de colônias para imigrantes, distribuição de lotes e condições de propriedade.

Martins (2002) afirma que por ordem do Dr. João Teodoro Xavier, Presidente da Província, em 1874, foram examinadas as possibilidades de se estabelecerem nas fazendas do município de São Paulo áreas dedicadas à colonização. Pouco depois o governo adquiriu as fazendas dos beneditinos para instalar nelas os núcleos coloniais que deviam ser ocupados pelos imigrantes.

Segundo Monteiro (1995), a política provincial da época entendia que o colono deveria permanecer algum tempo nas proximidades da capital. Nesse período foram fundados os núcleos coloniais de Santana e Glória em 
São Paulo e os de São Bernardo e São Caetano na Freguesia de São Bernardo. Os primeiros imigrantes, na maior parte italianos, do Núcleo Colonial de São Caetano chegaram em 28 de janeiro de 1877. Os da colônia de São Bernardo chegaram em 22 de julho do mesmo ano. Outro núcleo foi constituído em 1888, onde hoje existe o município de Ribeirão Pires. Eram centros agrícolas onde se produzia cereais, videiras e algodão. Mas também surgiam as olarias em toda a região e a exploração de granito para a construção de paralelepípedos e guias, em Pilar (Mauá) e Ribeirão Pires. E ainda a exploração da madeira, com as carvoarias e serrarias e depois a indústria do mobiliário, seguida pela têxtil.

No fim do Império, a Lei Provincial $\mathrm{n}^{\circ}$ 38, de 12 de março de 1889, desmembrou São Bernardo de São Paulo, possibilitando assim a constituição efetiva do início do que hoje conhecemos por ABC. Para administrar a Villa de São Bernardo foi criado o Conselho de Intendência, integrado por João Baptista de Oliveira Lima, José Del Zotto e Francisco José da Silva (02 de maio de 1890). Com a posse do primeiro intendente, José Del Zotto, a 11 de maio de 1890 foi instalado o município. A primeira Câmara Republicana foi eleita em 1892.

Os trilhos da São Paulo Railway, mais tarde Estrada de Ferro SantosJundiaí, atravessavam a várzea, vindos de São Paulo em direção a Santos. A implantação da ferrovia acarretou o fenômeno do "Povoado-Estação", caracterizado por pequenos núcleos, predominantemente residenciais e comerciais, com a localização de algumas indústrias extrativas como serraria, cerâmica e cimento (PASSARELLI, 1994). A estação de Ribeirão Pires data de 1887 , sendo que o núcleo colonial foi criado junto à estação. Em 1883, a São Paulo Railway inaugurou as estações do Pilar (hoje Mauá) e a de São Caetano, próximas ao núcleo colonial existente, e a estação Campo Grande, em 1889.

A Estação de São Bernardo, que havia sido inaugurada em 1867 e distava seis quilômetros do centro da Vila, cresceu rapidamente. Em 1910 o 
local se destacava como principal pólo de industrialização do município de São Bernardo, atraindo moradores de São Bernardo, em sua maioria italianos, interessados em melhorar suas condições de trabalho no parque fabril que ali se formava (MÉDICI, apud MONTEIRO, 1995). Nesse ano foi transformado em Distrito tendo alterado a denominação original para Santo André, lembrando a antiga povoação liderada por João Ramalho.

$E$ foi em função desse processo de crescimento industrial e residencial em torno do eixo ferroviário que ocorreu a transferência do poder políticoadministrativo do município, que teve sua sede deslocada para junto da estação ferroviária, o Distrito de Santo André (Decreto Estadual $n^{\circ} .9775$, de 30 de novembro de 1938). O município sede passou a chamar-se Santo André, contando com os seguintes distritos: São Bernardo, Mauá, Ribeirão Pires e Paranapiacaba, enquanto São Caetano passou a ser um sub-distrito do distrito sede (RODRIGUES, 1991).

A vocação industrial da região se fortaleceu com a construção da Represa Billings e da Usina Henry Borden (concluídas em 1952) e a inauguração da Via Anchieta (em 1947 e 1952, a $1^{\text {a }}$ e a $2^{a}$ pistas respectivamente). Foi escolhida para sediar a instalação das grandes multinacionais produtoras de veículos automotivos que chegavam ao Brasil atraídas pelo Plano de Metas do governo Juscelino Kubitschek, na segunda metade dos anos 50. Com isso aumentou o contingente de migrantes, primeiro do interior do estado, mais tarde dos estados de Minas Gerais e do Nordeste.

Ao mesmo tempo consolida-se a metropolização, sendo o crescimento dessa região em grande parte reflexo da expansão urbana da região metropolitana, em particular de seu centro principal, São Paulo (GOMES, 1993).

Esse desenvolvimento foi um dos fatores para os desmembramentos políticos que se sucederam. Em 1940 existia apenas um município, Santo André da Borda do Campo. Nos anos seguintes uma série de 
desmembramentos reconfigurou a região. O Decreto $n^{\circ} 14.344$, de 30 de novembro de 1944, eleva novamente São Bernardo à categoria de município, com o nome de São Bernardo do Campo. No dia 01 de janeiro de 1945 foi instalado o município e tomou posse o primeiro prefeito nomeado, Wallace Cochrane Simonsen. As eleições ocorreram no final de 1947 e em 1948 tomaram posse o primeiro prefeito eleito, Dr. José Fornari e a primeira Câmara de Vereadores.

Um plebiscito realizado em 1948 determinou a emancipação do distrito de São Caetano; a Lei $\mathrm{n}^{\circ} 233$ instalou o município com a denominação São Caetano do Sul. No dia 13 de abril de 1949 tomaram posse o primeiro prefeito de São Caetano do Sul, Dr. Ângelo Raphael Pellegrino e a primeira Câmara de Vereadores. Os distritos de Mauá (antigo Pilar) e Ribeirão Pires separam-se de Santo André, segundo a Lei $n^{\circ} 2.456$, de 30 de dezembro de 1953. No dia $1^{\circ}$ de janeiro de 1955 tomou posse $01^{\circ}$ prefeito de Mauá, Ennio Brancalion, e a primeira Câmara de Vereadores.

Os eleitores aprovaram no plebiscito de 24 de dezembro de 1958, a emancipação do distrito de Diadema de São Bernardo do Campo, regulamentada pelas Leis $n^{\circ} 5.121$, de 31 de dezembro de1958 e 5.285/59. No dia $1^{\circ}$ de janeiro de 1959 , tomaram posse o prefeito Evandro Caiaffa Esquível e a primeira Câmara Municipal.

O distrito de Icatuaçu, antigo Rio Grande, atingiu autonomia, separando-se de Ribeirão Pires, com o nome de Rio Grande da Serra (Lei $\mathrm{n}^{\circ}$ 8050, de 31 de dezembro de 1963).

Assim constituíram-se os sete municípios da região do Grande ABC paulista: Santo André, São Bernardo do Campo, São Caetano do Sul, Diadema, Mauá, Ribeirão Pires e Rio Grande da Serra. A fragmentação político territorial, entretanto, não eliminou uma identidade que tem como ponto de partida uma história comum, e possui ainda outros traços identitários, a forte influência dos imigrantes, o papel do trabalho como valor de agregação social, expandido com a pujança da industrialização da região 
entre as décadas de 50 a 80 , trazendo consigo a migração do norte e nordeste do Brasil (ALVES, 1999). A partir dos anos 60 temos a intensificação do fluxo populacional e a expansão dos municípios da região. Segundo dados do IBGE, de 1960 a 1991 a população absoluta do Grande ABC passou de 504.416 para 2.048.674 habitantes. Enquanto na década de 60/70 o Brasil apresentou 2,9\% de Taxa Geométrica de Crescimento Anual, o Grande ABC, no mesmo período, alcançou a marca dos $7 \%$.

Quanto à expressão Grande ABC, surgiu em 1968 quando o periódico News Seller, que circulava na região desde 1958 passou a adotar a denominação Diário do Grande $\mathrm{ABC}$, reforçando esta identidade.

Em 1987, surgem o Gipem - Grupo Independente de Pesquisadores da Memória do Grande ABC e a Coluna Memória, no jornal Diário do Grande ABC. O responsável por esta coluna, jornalista Ademir Médici, memorialista e integrante do Gipem nas suas origens, mantém esta coluna diária até hoje.

Por iniciativa do Gipem, orientação do professor José de Souza Martins e apoio do então prefeito de Santo André, Celso Daniel, um defensor do estudo e das ações da regionalidade, realizou-se em 1990 o primeiro Congresso de História do Grande ABC. Estes Congressos têm se realizado desde então a cada dois anos nos municípios do Grande ABC. Essas iniciativas estão ligadas à pesquisa da identidade e de outros assuntos relevantes para o entendimento da região. Os temas dos Congressos corroboram esta preocupação:

I - 1990 - Santo André: A classe trabalhadora em seu lugar

II - 1992 - São Bernardo: Caminhos e Rumos - Índios, Escravos e Operários

III - 1994 - São Caetano: À sombra das chaminés - a produção da cultura no $A B C$

IV - 1996 - Diadema: Os tempos históricos no ABCD paulista

V - 1998 - Mauá: História em silêncio: a (des)ocultação da história do 
povo do Grande ABC

VI - 2000 - Ribeirão Pires: Nós, os suburbanos

VII - 2002 - Rio Grande da Serra - Matas, águas e trilhas: Caminhos do $A B C$

O VIII Congresso voltou a ser realizado em Santo André, no distrito de Paranapiacaba, em julho de 2004, com o tema, "No meio dos caminhos, o Grande ABC."

A conceituação de região extrapola os indicadores geográficos e administrativos e abrange particularidades, sobretudo econômicas que identificam a região do Grande ABC. Para Daniel e Somekh (apud BERBEL, 2001), o Grande $A B C$ seria uma região plenamente distinguível por apresentar características econômicas peculiares, ser altamente polarizada e apresentar elevado grau de integração político-administrativa. Esta polarização seria resultado do fato de que cerca de $90 \%$ do movimento das pessoas ocorre dentro dos limites da região. A integração regional, do ponto de vista político e administrativo resultaria da existência de entidades cuja atuação extrapolam os limites de cada um dos sete municípios que compõem o Grande ABC.

O tema da integração ganhou ênfase após a abertura do mercado interno para os veículos automotores importados. Além disso, a indústria automotiva passa a diversificar localização, isto é, o Grande $A B C$ perde o quase monopólio da produção de autos no Brasil. Caracterizando as transformações sofridas pelo Grande $A B C$, nas últimas décadas dos século XX, Daniel (2001), considera,

"Ao processo de desconcentração territorial da indústria soma-se a retração da indústria nacional na década perdida, os anos 80 , iniciandose período de crise estrutural para o Grande ABC. (...) A década de 90 é de aprofundamento da crise e da emergência do novo: de um lado, 
manifestações da crise estrutural iniciada nos anos anteriores, às quais se agregam novas dimensões de problemas; de outro, a emergência de transformações que começam a apontar a superação da referida crise, com base em um modelo de desenvolvimento regional."

Assim, o rápido e desordenado crescimento da região e a crise econômica e social a partir do final dos anos 80 são responsáveis pela constituição de um novo regionalismo no $A B C$,

"Nos últimos 10 anos essa visão regional voltou-se para as políticas públicas. A criação de órgãos como o Consórcio Intermunicipal, o Fórum da Cidadania, a Câmara Regional e a Agência de Desenvolvimento é o resultado concreto da convergência de esforços para a estruturação de um campo institucional propício ao desenvolvimento das políticas regionais. São várias as razões: crise econômica, emergência de novas formas de gestão participativa, constituições de blocos partidários fortes, acumulação de problemas que não poderiam ser mais tratados isoladamente por município, como a questão dos mananciais e da destinação e tratamento dos resíduos urbanos e industriais, entre outros." (BERNARDO, 2001).

A primeira organização oficial constituída neste sentido foi o Consórcio Intermunicipal das Bacias do Alto Tamanduateí e Billings, que congrega as sete prefeituras dos municípios da região do Grande $A B C^{2}$. Também conhecido como Consórcio Intermunicipal Grande ABC e Consórcio ABC, foi instalado oficialmente na Câmara Municipal de Santo André, em 19 de dezembro de 1990. Essa associação dos sete municípios do Grande ABC foi autorizada por leis municipais daquele ano, nos termos da Constituição Federal, da Constituição Estadual e das Leis Orgânicas dos municípios. Além

\footnotetext{
${ }^{2}$ Os consórcios intermunicipais representam acordo dos municípios envolvidos para fins administrativos. São formas ágeis e albergadas pelo Direito de enfrentamento de problemas locais e regionais, dentro de áreas setoriais definidas, como saúde, distribuição de gás, terceirização e tantos outros serviços que terão solução à vista da boa governança no uso dos interesses e mecanismos das políticas públicas (Castro, 2001).
} 
dos sete prefeitos e dos assessores indicados por eles para assuntos regionais, o Consórcio conta ainda com um Conselho Fiscal, formado por membros indicados pelas Câmaras de Vereadores de cada cidade e um Conselho Consultivo constituído por membros de entidades da sociedade civil. A presidência do Consórcio é exercida por um dos prefeitos, eleito por seus pares por um ano.

Um de seus primeiros objetivos é o de representar o conjunto dos sete municípios consorciados em matérias de interesse comum perante outras entidades, além de defender políticas consensuais para o desenvolvimento da região.

Como exemplo de atividades já concretizadas ou em desenvolvimento pelo Consórcio Intermunicipal Grande $A B C$ temos o Plano de Obras Emergenciais em Áreas de Proteção aos Mananciais, o Plano Regional de Coleta e Disposição Final de Resíduos Sólidos, o Plano Regional de Controle Ambiental, o Plano Regional Viário, o Plano Regional contra Enchentes.

O Fórum da Cidadania do Grande $A B C$, cuja missão é fazer que sejam respeitados os direitos e a cidadania, teve sua origem no "Movimento Vote no Grande ABC", no ano eleitoral de 1994, sendo seu objetivo sensibilizar e conclamar a população da região do $A B C$ a aumentar sua representação na Câmara Federal e na Assembléia Legislativa, votando nos candidatos da região. Como resultado foram eleitos cinco deputados federais e oito estaduais, a maior representação parlamentar já verificada na região.

Cumprida a finalidade, as entidades participantes do movimento, apoiadas por outras entidades representativas da vida civil, entenderam que o movimento deveria institucionalizar-se. Surgiu então, o Fórum da Cidadania do Grande ABC, constituído formalmente no dia 16 de março de 1995. Atualmente conta com mais de uma centena de entidades dos mais diversos segmentos da sociedade civil que por meio de seus Grupos Temáticos atuam promovendo debates, seminários, palestras, encontros e estudos com o objetivo de apresentar às autoridades constituídas, seja nos âmbito federal, 
estadual e municipal e à população em geral, os subsídios que, de alguma forma, possam ajudar na solução dos problemas da região. ${ }^{3}$

A Câmara do Grande $A B C$ reúne em um mesmo espaço poder público (governo do Estado e dos sete municípios que constituem o Grande $A B C$ ) e sociedade civil para que juntos realizem um planejamento estratégico, no sentido de equacionar e buscar soluções para a problemática social, econômica, ambiental, físico-territorial e circulação e de transportes da região. As prioridades são estabelecidas de acordo com diagnósticos formulados pela Câmara, em especial, pelos Grupos Temáticos (GTs). A idéia de sua criação foi lançada em 1996 pelo governo de São Paulo, mas sua efetivação só foi possível no dia 12 de março de 1997, após os novos prefeitos assumirem seus cargos.

Os diversos parceiros articulados na Câmara Regional do Grande ABC realizaram em 1999 o Planejamento Estratégico Regional, que elaborou um "cenário futuro" desejado para o Grande $A B C$, ou seja, uma visão de como poderia ser a região - de um conjunto de "eixos estruturantes" - a saber: as pré-condições necessárias para tornar aquele cenário uma realidade, e um programa e uma estratégia para viabilizar tais eixos (Revista Câmara do Grande ABC, s.d.).

Os "eixos estruturantes" definidos pelo Planejamento Estratégico Regional são: Educação e Tecnologia, Áreas de Mananciais, Acessibilidade e Infra-Estrutura, Cadeias produtivas, Ambiente Urbano de Qualidade, Identidade Regional e Estruturas Institucionais e Inclusão Social.

Finalmente, a Agência de Desenvolvimento Econômico do Grande $A B C$ é a concretização de um dos acordos mais importantes da Câmara. Foi criada em 1998, visando otimizar os trabalhos da Câmara Regional do Grande $A B C$, para promover o Desenvolvimento Econômico Sustentável Regional. Trata-se de uma ONG mista, composta pela associação das sete Prefeituras (representadas pelo Consórcio Intermunicipal do Grande $A B C$ ),

\footnotetext{
${ }^{3}$ Folder institucional "Fórum da Cidadania do Grande ABC - Aqui o Grande ABC fala mais alto".
} 
por todas as Associações Comerciais e Centros das Indústrias (Ciesps) da região, ao lado do Sebrae, das empresas do Pólo Petroquímico, das principais instituições de ensino (Universidades e Faculdades) ${ }^{4}$ e dos maiores Sindicatos de Trabalhadores, sendo que todos esses segmentos têm ação efetiva em sua diretoria. ${ }^{5}$

A Agência de Desenvolvimento Econômico foi concebida como uma instituição de natureza executiva com a finalidade de conduzir ações de marketing regional, coordenar as ações técnico-financeiras de apoio e fomento às empresas e produzir e disseminar informações sócio-econômicas da região.

Nesta ótica de regionalidade, de pensar, estudar, propor e desenvolver ações sobre a região do Grande $A B C$, outras duas iniciativas devem ser mencionadas.

Em 1998, quando das discussões preparatórias ao $5^{\circ}$ Congresso de História do Grande $A B C$, tomou corpo a idéia da criação de um fórum que congregasse as instituições oficiais de história e memória da região: Museu de Santo André, Serviço de Memória e Acervo e Serviço de Patrimônio Histórico de São Bernardo do Campo, Fundação Pró-Memória de São Caetano do Sul, Centro de Memória de Diadema, Museu de Mauá e Museu de Ribeirão Pires. Este fórum denominou-se "Comissão Técnica das Instituições de Memória do Grande ABC". Constituiu-se objetivando maior integração regional e intercâmbio técnico-científico. Para tanto seus integrantes, museólogos, historiadores, especialistas em arquivística e museologia, bibliotecários e sociólogos, reunem-se mensalmente para discutir, trocar informações, realizar trabalhos comuns e projetar ações futuras. Têm realizado ações na ótica da integração regional, como a organização temática do VI Congresso de História do Grande ABC e a elaboração de um guia, Grande $A B C$ - Guia Bibliográfico: localização e

\footnotetext{
${ }^{4}$ As Universidades se constituem sócias da Agência através do Unifórum (Livre Mercado, 2001).

${ }^{5}$ Folder Institucional "Agência de Desenvolvimento Econômico do Grande ABC - Conhecendo o passado, inovando o presente, construindo o futuro".
} 
síntese de conteúdo, editado em 2001, com o patrocínio do Consórcio Intermunicipal Grande ABC.

Além das instituições mencionadas passaram a fazer parte dessa Comissão Técnica, o Centro de Apoio Técnico ao Patrimônio de Ribeirão Pires, o Núcleo de Pesquisa Histórica de Mauá e a Gerência de Projetos Patrimoniais de Paranapiacaba. Seus objetivos, características e atuação, foram sintetizados como,

"Um dos grandes desafios da Comissão Técnica tem sido encontrar eixos de comunicação comuns tratando-se de instituições participantes Centros de Memória, Museus, Serviços de Patrimônio Cultural - com linguagens e preceitos teórico-metodológicos diversos. Além disso, existem características políticas, econômicas, sociais e culturais próprias a cada município da região. No entanto, o que une as instituições é sua importância no contexto social com vistas a propiciar a produção, conservação e difusão do conhecimento histórico do Grande $A B C$, a história regional comum até meados da década de 1940 e a compreensão da importância da realização de ações regionais.

As ações desenvolvidas pela Comissão Técnica apresentam-se como trabalhos coletivos e não como a justaposição das ações desenvolvidas em cada uma das instituições. Os interesses, demandas e calendários são diferenciados." ${ }^{\prime}$

Também em 1998, foi criado o Laboratório de Regionalidade e Gestão do Centro de Aperfeiçoamento e Pós-Graduação do Centro de Aperfeiçoamento e Pós-Graduação do Centro Universitário do Imes-Instituto Municipal de Ensino Superior de São Caetano. Idealizado pelo professor Luiz Roberto Alves, o laboratório tem como principal objetivo realizar estudos sobre o desenvolvimento social, econômico e educacional do Grande ABC e

\footnotetext{
${ }^{6}$ Suzana Cecília Kleeb. Comunicação sobre a Comissão Técnica das Instituições Oficiais de Memória do Grande ABC, apresentada na Semana de Museus, Universidade de São Paulo, 2003.
} 
outras regiões do país. Sua proposta é criar mestres em Administração para pesquisar a regionalização como contraponto a globalização. Esclarece Alves,

"A despeito dos números e perspectivas - cujo pano de fundo revela o Grande $A B C$ como o terceiro pólo de consumo do país e um dos líderes nacionais de renda per capita, cerca de $\mathrm{R} \$ 12$ mil (quando a do Brasil é de R\$ 4 mil) - há aqui, porém, uma grande ausência: a produção do conhecimento científico capaz de embasar reflexões, propostas de mudança, exigências administrativas. Muitos depoimentos de projetos bem-sucedidos em cidades e regiões do mundo mostraram o peso das ações científico-culturais, nas quais as dimensões especializadas como educação, ecologia, administração, comunicação social criaram, acumularam e veicularam intensa massa crítica para o alcance de objetivos definidos socialmente na sociedade mais complexa. ( Diário do Grande $A B C, 1998)$.

O LabGest, como também é conhecido, tem constituído um acervo com trabalhos acadêmicos e uma hemeroteca sobre a região do $A B C$. Periodicamente realiza seminários, palestras e debates sobre temas relevantes focalizando as várias faces da regionalidade que são publicados nos Cadernos de Pesquisa Ceapog-Imes. E tem como temas de estudo: experiências de gestão urbana regionalizada; os desafios da sociedade regional; reflexões acadêmicas entre o global e o local.

Recentemente, a exemplo da Comissão Técnica das Instituições de História e Memória,

“(...) secretários municipais e diretores de Cultura dos sete municípios do Grande $A B C$ criaram um grupo técnico dentro do Consórcio para cuidar das políticas regionais do setor. Os administradores da questão cultural das cidades querem abordar a necessidade de um sistema regional de cultura, integração dos serviços culturais fornecidos pelas 
sete cidades, administração conjunta da memória regional (sic) e da formação e formação de corpo técnico e artístico nas sete cidades. O grupo terá reuniões mensais e já propõe inclusive um seminário regional de cultura para ampliar o debate em torno do assunto" ( Diário do Grande $A B C$, 2003).

Assim, em vários sentidos e direções os municípios e suas entidades têm procurado superar a fragmentação buscando ações integradoras. Esta consciência e atuação regional que vem sendo construída é constatada pelo professor Fernando Abrucio, o autor de Redes Federativas no Brasil: Cooperação Intermunicipal no Grande $\mathrm{ABC}$, afirma "o Consórcio Intermunicipal, único em regiões metropolitanas está um passo à frente de outras experiências" e que, "existe uma agenda regional e a sociedade civil sabe o que é atuação regional e atuação metropolitana." ${ }^{8}$

\footnotetext{
${ }^{7}$ O Seminário proposto realizou-se efetivamente de 21 a 23 de agosto de 2003, na sede do Consórcio Intermunicipal Grande ABC com o tema, "ABC: Desafios da Complexidade Cultural. Identidades e Produção Simbólica no Mundo do Trabalho".

${ }^{8}$ Informativo do Consórcio Intermunicipal do Grande ABC, dez $/ 1^{\circ}$ de janeiro de 2002).
} 


\title{
3 - As administrações públicas municipais no $A B C$ e seus arquivos
}

\author{
"O Brasil só precisa de uma lei. Uma lei \\ que diga que é preciso cumprir todas as leis". \\ Antonio F. Viana, gaúcho, deputado pelo Rio de Janeiro (1832-1905) ${ }^{9}$
}

\section{1 - O Município e os Arquivos Municipais}

Quando se trata da caracterização do "município" no Brasil sempre é evidenciada sua autonomia, que remonta ao período colonial. Herança portuguesa efetivada no Brasil com a criação das vilas ${ }^{10}$ e a instalação das Câmaras Municipais que conforme Meirelles (1964), "possuíam a mesma organização e atribuições políticas, administrativas e judiciais que desempenhavam no Reino".

Em Portugal, o Concelho, órgão local de governo era exercido por um alcaide, com funções administrativas e judiciais, juízes, escolhidos entre os homens bons que constituíam um órgão consultivo ao Concelho, os almotacés, com funções de policiamento, de pesos e medidas, conservação de estradas, edificações e tributos, e os procuradores, representantes do Concelho junto à Corte.

Segundo Castro (2001), as Comunas portuguesas sofreram no final da Idade Média, o mesmo declínio que em outros lugares da Europa, em proveito do fortalecimento do poder central. Conseqüentemente, no século XIV aparecem os representantes da Coroa nos Concelhos, chamados "juízes de fora", símbolo do centralismo, do controle.

\footnotetext{
${ }^{9}$ Roberto Pompeu de Toledo. Ao Brasil, com amor, desprezo ou escárnio. Revista Veja, 30/07/2003, p.130.

${ }^{10}$ A primeira vila no Brasil foi São Vicente, fundada por Martim Afonso de Souza, em 1532.
} 
Com as Ordenações Afonsinas (1446) é criada a figura do vereador, "de verear, aquele que vigia pelas veredas da vida, vê alto, provê os interesses de todos" (Castro, 2001). Os vereadores passam a dividir suas funções com os almotacés e com os homens bons. Sua instituição foi mantida nas Ordenações Manuelinas (1521) e nas Ordenações Filipinas (1603). ${ }^{11}$

Chegando ao Brasil trouxeram os portugueses as instituições municipais segundo o direito vigente na época. Apesar da instituição das Capitanias Hereditárias ${ }^{12}$, a vastidão do território, a distância da Metrópole, a preocupação da Coroa Portuguesa com a Guerra com a Espanha e com as Índias, e mesmo o sentimento nativista do povo que se formava, contribuíram para o fortalecimento da autonomia dos municípios.

"No Brasil, a cidade sempre teve - numa tradição que remonta ao período colonial - um papel e um tratamento político destacado. Nossa formação histórica e cultural, herdada da colonização portuguesa, é municipalista, tendo o Município precedido a própria formação nacional (...) as Câmaras Municipais do Brasil-colônia, com sede nas vilas e cidades, desempenhavam as mais variadas competências e foram o único órgão que sobreviveu por inteiro (...)" (REIS, 2002).

As Ordenações Filipinas, promulgadas em 1603 na Espanha ${ }^{13}$ reduziram a organização municipal a um aparelhamento de finalidades puramente administrativas. As funções judiciais ficaram restritas a pequenos casos que a legislação da época relegava para os tribunais locais.

\footnotetext{
${ }^{11}$ As Ordenações são codificações inspiradas nos usos e costumes, leis gerais, forais, regulamentos, além dos princípios dos direitos romano, canônico e visigótico. Vigoraram no Brasil as Ordenações Afonsinas (14461447), as Manuelinas, com uma primeira versão de 1512, sendo novamente redigida em 1521, e as Filipinas (1603).

${ }^{12}$ Criadas a partir de 1534 por D. João III, que dividiu as terras braileiras, do litoral até a linha de Tordesilhas, em quinze faixas de terra, de extensão variável, doadas doze capitães donatários, fidalgos da pequena nobreza portuguesa. Juridicamente a ocupação das terras era assegurada pela Carta de Doação e pelo Foral.

${ }^{3}$ De 1580 a 1640, Portugal e suas colonias estiveram sob domínio espanhol.
} 
Após a independência de Portugal, em 1824, nossa primeira Constituição reservou às Câmaras Municipais um capítulo autônomo ${ }^{14}$ :

- Artigo 167 - Em todas as Cidades e Vilas ora existentes e nas mais que para o futuro sejam criadas, haverá Câmaras, às quais compete o governo econômico e municipal das mesmas cidades e vilas.

- Artigo 168 - As Câmaras serão eletivas, e compostas do número de vereadores que a Lei designar, e o que obtiver mais número de votos será o Presidente.

- Artigo 169 - O exercício de suas funções municipais, promoção das suas Posturas policiais, aplicação de suas rendas e todas particulares e úteis atribuições, serão decretadas por uma Lei regulamentar.

Como hoje há distinção político-administrativa nas expressões "Cidades" e "Vilas", esclarece Castro (2001) que, "no Império, a diferença entre cidade e vila identificava-se apenas pelo critério democrático e pela composição dos membros das Câmaras Municipais. E que as Câmaras das cidades eram compostas de nove membros, além do secretário e as das vilas, de sete".

Entretanto em $1^{\circ}$ de outubro de 1828 foi aprovada a Lei Regulamentar $\mathrm{n}^{\circ} 28$, retirando dos municípios qualquer capacidade deliberativa, e o Ato Adicional à Constituição de 12 de agosto de 1834 passa a atrelar as Câmaras às Assembléias Provinciais. Assim, conforme Costa (1996),

"No Império, mesmo que a Constituição de 1824 previsse eleições nas vilas e cidades, as instituições locais eram subordinadas aos Presidentes das Províncias e ao Governo Central, não tendo autonomia. Porém, mesmo assim, os chefes políticos locais, com imenso poderio privado, tornavam o governo central do Império impotente para exercer de fato maiores controles sobre o mando dos chefes locais".

\footnotetext{
${ }^{14}$ Capítulo II, Das Câmaras, Título VII.
} 
Essa condição perdurou até o advento da República, pois,

“(...) os Municípios foram praticamente excluídos do texto constitucional, sendo considerados como "assunto doméstico das Províncias", numa indiferença que se manteve até a Constituição Federal de 1891, primeira da República, que apenas determinou, em seu famoso art. 68, que "os Estados organizar-se-ão de forma que fique assegurada a autonomia dos Municípios, em tudo quanto respeite ao seu peculiar interesse" (REIS, 2002).

Prevaleceu aqui a ascendência dos Estados, na organização dos seus respectivos Municípios, tarefa apenas limitada pelo respeito ao peculiar interesse, jamais definido com contornos objetivos. Isso representou um golpe na autonomia municipal, abandonou às conveniências políticas dos governos estaduais, que colocaram os Municípios a serviço dos interesses oligárquicos que imperaram durante toda a República Velha. Segundo Cretella Jr. (1975),

“ (...) a autonomia municipal ficou apenas no papel, porque dentro de mais de quarenta anos, na prática, imperava no Município, a vontade do Governo Estadual, representado pelo chefe do situacionismo local. Cabos eleitorais, os "coronéis", os chefes locais, representantes do governo do Estado é que mandavam na política municipal".

Por fim, como afirma Meirelles (1964) o "Município brasileiro era reduto de políticos que os transformavam em feudos" e que vivia "sem recurso, sem liberdade, sem progresso, e sem autonomia".

Da Constituição de 1891 à atual, tivemos a alternância entre fases de maior autonomia dos estados e municípios e centralismo político nas mãos do governo federal. 
A Reforma Constitucional de 1926 incluiu a autonomia municipal entre os princípios constitucionais da União, mas passou a permitir a intervenção federal no Estado que a desrespeitasse. Portanto, a autonomia local passaria a comportar uma interpretação federal, e não apenas a interpretação que lhe desse o Estado-membro no exercício do poder de organização do Município.

A Constituição de 1934 iniciou o processo emancipador do Município. Criou as condições necessárias ao florescimento do municipalismo e corrigiu os abusos cometidos, durante a República Velha, na organização plena do Município pelo Estado. Um dos grandes passos dados pela Carta de 1934 no sentido de alargar a substância da autonomia local, foi o reconhecimento, aos Municípios, de uma autonomia financeira, de modo que passaram a gozar de receitas próprias.

Durante a ditadura do Estado Novo, vigência da Carta outorgada de 1937, vigorava um governo densamente autoritário e centralizador, concentrado de modo pessoal nas mãos de Vargas. Os prefeitos passaram a ser de livre nomeação dos governadores, então chamados de Interventores do Estado, e estes eram indicados pelo Chefe do Governo.

Promulgada após a queda do Estado Novo e a redemocratização do país, a Constituição de 1946 novamente reconheceu aos Municípios aquela autonomia já obtida com a Constituição de 1934. Seus prefeitos, viceprefeitos e vereadores eram eleitos diretamente pelo povo. Definiu-lhes competências tributárias e previu a sua participação no produto da arrecadação do imposto de renda pela União.

A Constituição de 1967, e também a Emenda Constitucional $n^{\circ} 1$ de $1969^{15}$, alargaram a matéria de interesse municipal no texto da Constituição Federal, limitando a autonomia do Estado-membro nesse tema. Durante os anos dos governos militares, houve uma intensa interferência da União - em

\footnotetext{
${ }^{15}$ Esta Emenda determinava que os prefeitos das capitais dos estados e dos municípios considerados estâncias hidrominerais passariam a ser nomeados pelos governadores dos estados, ouvida a Assembléia Legislativa, e os dos municípios considerados de interesse da segurança nacional, pelo presidente da República. Limitou também o número de vereadores a vinte e um, o que prejudicava a representação política de cidades mais populosas.
} 
assuntos de interesse tipicamente municipal, uma tendência centralizadora que, aliás, foi característica daquele regime.

Nos anos 80, cresceu vigorosamente o movimento municipalista e os avanços descentralizadores que se verificaram no decorrer desta década foram ratificados e aprofundados pela Constituição de 1988 (AFFONSO, 1996).

Essa descentralização,

"constituiu-se numa peça central da agenda reformista da Nova República, em virtude de dois desenvolvimentos. Em primeiro lugar, a centralização característica do autoritarismo burocrático do regime militar converteu a descentralização num princípio ordenador das mudanças para os setores de esquerda ( ...) Por outro lado, a descentralização constituía-se numa peça também importante do pensamento liberal de oposição ao regime. Na Nova República, as duas matrizes - a esquerda e a direita - engendraram uma coalizão frouxamente articulada, mas que logrou conferir um forte viés municipalista não só à Constituição de 1988, como também às diversas propostas de políticas" (MELO, 1996).

Foi a Constituição de 1988 que deu à autonomia municipal a mais avançada proteção e a mais ampla abrangência, como jamais ocorrera em momentos anteriores de nossa experiência constitucional (BENEVIDES, apud REIS, 2002).

A grande inovação trazida pela Constituição foi o rompimento com a tradição dual do federalismo brasileiro - desde 1891 baseado na repartição de competências entre apenas duas ordens de entidades federativas, a União e os estados, - passando a inserir, categoricamente, os Municípios na organização político-administrativa da República Federativa do Brasil, formando-se uma terceira esfera de autonomia. Conforme o artigo 18 da Constituição Federal de 1988, "A organização político-administrativa da 
República Federativa do Brasil compreende a União, os Estados, o Distrito Federal e os Municípios, todos autônomos, nos termos desta Constituição."

Discorrendo sobre a singularidade do Município brasileiro, a partir da Constituição de 1988, Meirelles (2002) afirma ser o mesmo uma "entidade estatal integrante da Federação. Essa integração é uma peculiaridade nossa, pois em nenhum outro Estado Soberano se encontra o Município como peça do regime federativo constitucionalmente reconhecida. Dessa posição singular do nosso Município é que resulta sua autonomia políticoadministrativa, diversamente do que ocorre nas demais federações em que os Municípios são circunscrições territoriais meramente administrativas."

Quanto à autonomia do Município brasileiro está assegurada na Constituição da República para todos os assuntos de seu interesse local (art. 30) e se expressa sob o tríplice aspecto político (composição eletiva do governo e edição de normas locais), administrativo (organização e execução dos serviços públicos locais) e financeiro (decretação, arrecadação e aplicação dos tributos municipais).

O artigo 29 da Constituição Federal estabelece que a organização político-administrativa é feita pelo próprio Município, por lei orgânica local, votada e aprovada por dois terços dos membros da Câmara Municipal, sendo promulgada pela mesma Câmara, atendidos os preceitos estabelecidos na Constituição.

Assim podemos afirmar que hoje o município, "constitui uma instituição político-jurídica (...) que agrega grupos de pessoas, que estrutura uma peculiar organização econômica e, para a qual, o Estado vê-se forçado a criar uma rede de serviços locais e caracterizá-lo como uma célula do próprio Estado" (SALGADO, 1989).

$\mathrm{O}$ artigo 30, inciso $\mathrm{V}$ da Constituição Federal de 1988, estabelece que "aos municípios foram reservados todos os serviços públicos que digam respeito ao interesse local", e os incisos VI e VII introduziram a responsabilidade do município nas áreas de Educação e Saúde. Portanto, 
passam também para a esfera municipal, serviços como a promoção de programas de construção de moradia e a melhoria de condições habitacionais e de saneamento básico, a constituição de guardas municipais, o atendimento em creches, etc. A própria assistência social será descentralizada, cabendo aos municípios e estados a execução de programas coordenados e normatizados pela União (artigo 210, parágrafo $\left.2^{\circ}\right)$.

Além das características político-administrativas apontadas, possuem os municípios outras características próprias, "os laços comunitários são mais sólidos", afirma Figueira (1991), acrescentando que o município "constitui uma espécie de instituição total: nele, as relações sociais, políticas e econômicas são muito mais visíveis e diretas, umas influenciam fortemente as outras". Até porque, "Ninguém mora na União. Ninguém mora no Estado. Todos moram no município"16.

Ao crescimento da estrutura administrativa e de serviços para atender as demandas locais, corresponde o crescimento da documentação produzida, espelho da administração e de suas relações com a comunidade, como afirmam Machado e Camargo (1999),

\begin{abstract}
"Qualquer que seja o tamanho do município existe uma estreita correspondência entre a demanda social de serviços e as instituições do poder público criadas para satisfazê-las. A circulação de documentos e sua acumulação em arquivos são uma conseqüência natural desse processo, uma espécie de produto necessário para o funcionamento de cada órgão: ao mesmo tempo em que constituem instrumentos ou veículos da ação do governo municipal, os documentos testemunham as relações destes com a comunidade a que serve, daí o interesse que continuam mantendo para as próprias instituições e para os munícipes."
\end{abstract}

\footnotetext{
${ }^{16}$ Esta afimação, muito repetida pelos municipalistas, é associada a André Franco Montoro, tendo o CEPAMCentro de Estudos e Pesquisas de Administração Municipal, reproduzido a frase e o nome do mesmo em inscrição na entrada da instituição.
} 
Entretanto o desconhecimento de suas características e a inexistência de uma eficiente gestão desses documentos provocam sua desvalorização, seu abandono e muitas vezes, sua destruição. Forma-se uma espécie de círculo vicioso,

"de um lado, há o desconhecimento do administrador do potencial que o arquivo de sua organização pode representar em informações necessárias às suas decisões. De outro lado, há depósitos atulhados e sem processamento técnico, que não são capazes de responder às perguntas eventualmente formuladas pelos administradores" (BILLOTTA et al., 1984).

Também quanto à dificuldade do Estado de gerenciar a informação e nós completaríamos, os arquivos públicos como repositórios de informações, afirma Malin, (1994),

“(...) ela (a informação) não é tratada socialmente como recurso e a idéia de uma política para governar sua criação, distribuição e uso parece bizarra.(...) Em relação à produção e tratamento da informação, o terreno então é completamente virgem: o Estado é depositário de enorme e desconhecida massa de informações subutilizadas e em muitos casos inúteis, cujo custo de manutenção é incalculável".

Entretanto, Robert Troismont (apud SALGADO, 1989), referindo-se à administração pública afirma que informação técnica, científica e administrativa, dados numéricos e estatísticos são necessários para tomar decisões, elaborar regulamentos, confeccionar anteprojetos legislativos, organizar estruturas administrativas, elaborar projetos e programas de trabalho, organizar instituições, controlar a gestão pública, etc.

No desempenho de sua função administrativa cabe aos poderes públicos municipais, de acordo com as normas constitucionais atuais, efetuar 
o planejamento ${ }^{17}$ e estabelecer os programas a serem executados. Essas atividades devem estar apoiadas em informações organizadas, fidedignas, que reflitam a realidade municipal.

Se por um lado a Constituição de 1988 delegou aos municípios autonomia para planejar, e determinou a responsabilidade da execução dos serviços de Educação, Saúde e atribuições quanto à Habitação, Assistência Social, Guarda Municipal, entre outras, qual seria a responsabilidade dos municípios com relação à documentação gerada no exercício destas e de suas outras funções?

A Constituição de 1988 e posteriormente a Lei Federal $n^{\circ}$ 8.159, de 1991 são as principais referências legais para a resposta a essa questão.

O texto constitucional de 1988 estabelece em seu artigo 216, parágrafo $2^{\circ}$, "Cabem à administração pública, na forma da lei, a gestão da documentação governamental e as providências para franquear sua consulta a quantos dela necessitem".

Quanto à questão da informação, segundo o artigo $5^{\circ}, \mathrm{XIV}$, "é assegurado a todos o acesso à informação e resguardado o sigilo da fonte, quando necessário ao exercício profissional" e segundo o artigo XXIII, "todos têm direito a receber dos órgãos públicos informações de interesse particular, ou de interesse coletivo ou geral, que serão prestados no prazo da lei, sob pena de responsabilidade, ressalvadas aquelas cujo sigilo seja imprescindível à segurança da sociedade e do Estado".

Mas só com a instituição da Lei Federal $n^{\circ} 8.159^{18}$, sancionada em 8 de janeiro de 1991 e conhecida como "Lei de Arquivos", foram estabelecidos os princípios, atribuições e responsabilidades com relação aos arquivos públicos e privados. Previstos por esta lei com o objetivo de implementar

\footnotetext{
${ }^{17}$ São atribuições da administração municipal, o estabelecimento do Plano Diretor, do Plano de Governo, do Plano de Diretrizes Orçamentárias, do Plano Plurianual e do Orçamento Anual.

${ }^{18}$ A elaboração desta lei foi resultado de um longo processo que começou com a iniciativa do Arquivo Nacional e do Ministério da Justiça em 1980 criando uma comissão para elaborar um anteprojeto de lei relativo a uma "política nacional de arquivos". Foram 17 versões, até que um projeto de "lei de arquivos" (projeto no 4.895 A/84) passou a tramitar no Congresso Nacional (COSTA, Celia Maria Leite e FRAIZ, Priscilla Moraes).
} 
suas determinações, foram criados o CONARQ-Conselho Nacional de Arquivos (Decreto $\mathrm{n}^{0} 1.173$, de 29 de junho de 1994) ${ }^{19}$ e o SINAR-Sistema Nacional de Arquivos (Decreto $n^{\circ} 1.461$, de 25 de abril de 1950).

Entre outras determinações, a Lei $n^{\circ} 8.159$ estabelece:

- É dever do Poder Público a gestão documental e a proteção especial a documentos de arquivos, como instrumento de apoio à administração, à cultura, ao desenvolvimento científico e como elementos de prova e informação (artigo $1^{\circ}$ );

- A eliminação de documentos produzidos por instituições públicas e de caráter público será realizada mediante autorização da instituição arquivística pública, na sua específica esfera de competência (artigo 9);

- Os documentos de valor permanente são inalienáveis e imprescritíveis (artigo 10);

- É assegurado o direito de acesso aos documentos públicos (artigo 22);

- Ficará sujeito à responsabilidade penal, civil e administrativa, na forma da legislação em vigor, aquele que desfigurar ou destruir documentos de valor permanente ou considerado de interesse público e social (artigo 25).

Quanto à responsabilidade pela administração da documentação pública ou de caráter público, a mesma Lei estabelece em seu artigo 17, que esta compete às instituições arquivísticas federais, estaduais, do Distrito Federal e municipais ${ }^{20}$. Ao estabelecer que às instituições arquivísticas municipais cabe a administração dos documentos públicos do município, adequa-se a "Lei de Arquivos" ao artigo 18 da Constituição.

Devido ao caráter polissêmico da palavra "arquivos", é comum que ao serem indagadas sobre a instituição do Arquivo Público no município, autoridades municipais, inclusive da área jurídica, aleguem que o município possui arquivos públicos, referindo-se aos conjuntos documentais produzidos

\footnotetext{
${ }^{19}$ Após sua instalação o CONARQ tem estabelecido normas relativas a várias questões relacionadas aos arquivos públicos, através de "resoluções", a última, Resolução n ${ }^{\circ}$ 20, de 16/07/2004, dispõe sobre a inserção dos documentos digitais em programas de gestão arquivística de documentos dos orgãos e entidades integrantes do Sistema Nacional de Arquivos.

${ }^{20}$ Grifo nosso.
} 
pelos vários órgãos da administração, e que portanto, estariam cumprindo as exigências legais. É interessante lembrar a recomendação do CIA - Conselho Internacional de Arquivos, sobre o uso do termo Arquivo com maiúscula, como instituição, para distinguí-lo do conjunto dos documentos de arquivo com minúscula, mencionada por Heredia Herrera (2004).

Ainda quanto a expressão "instituições arquivísticas públicas", esclarece JARDIM (1999),

"são consideradas aquelas cuja atividade-fim é a gestão, recolhimento, preservação e acesso de documentos produzidos por uma dada esfera governamental (ex:: o Arquivo Nacional, os arquivos estaduais e os arquivos municipais). Os serviços arquivísticos governamentais referemse às unidades administrativas incumbidas de funções arquivísticas nos diversos órgãos da administração pública, no âmbito das quais configuram-se como atividades-meio (ex.: o Serviço e Protocolo e Arquivo do Departamento de Administração do Ministério da Saúde)".

Os municípios em geral possuem Serviços de Protocolo e Arquivo, vinculados às Secretarias de Administração ou de Governo que não podem ser confundidos com o Arquivo Público Municipal, instituição responsável pela gestão, recolhimento, preservação e acesso aos documentos públicos do município. A institucionalização do Sistema de Arquivos e do Arquivo Público Municipal deve ser feita por lei municipal, em obediência à Constituição atual e à Lei Federal n 8.159/91. Constituirão esse Sistema de Arquivos, os arquivos correntes, os arquivos centrais (se for o caso), o arquivo intermediário (muitas vezes corresponde nos municípios ao Arquivo Geral), e o arquivo permanente ou Arquivo Público Municipal e a legislação municipal ao constituir o sistema deve estabelecer funções, estrutura e competências para toda a rede, de forma que a gestão dos documentos se faça com eficiência e eficácia. 
Adequando-se à Constituição atual, todos os municípios votaram e colocaram em vigor sua Lei Orgânica. A leitura e análise das Leis Orgânicas dos municípios da região mostram que estes transcrevem o que estabelece a Constituição Federal no que respeita a questão da documentação. Assim todos incluem como competência do município quanto ao patrimônio histórico e documental: "proteger os documentos, as obras e outros bens de valor histórico, artístico e cultural, os monumentos, as paisagens naturais notáveis e os sítios arqueológicos, em colaboração com a União e o Estado; promover a proteção do patrimônio histórico-cultural local, observada a legislação e a ação fiscalizadora federal e estadual."

Em um estudo sobre o acesso aos documentos públicos, Costa e Fraiz (1989) afirmam que "O texto constitucional de 46 foi o primeiro a considerar a documentação de valor histórico como um bem a ser protegido pelo poder público. Até então, pela Constituição de 37, o patrimônio histórico era constituído apenas de "monumentos históricos e naturais, assim como as paisagens e os locais particularmente dotados pela natureza".

Segundo as autoras, o texto da Constituição de 1988 amplia o que foi estabelecido em 1946, graças a

“(...) proposta que o Arquivo Nacional encaminhou às subcomissões temáticas e que foi aproveitada, na sua totalidade, no novo texto constitucional é bem mais abrangente, nela incluindo-se a proteção do poder público, com a colaboração da comunidade, ao patrimônio cultural brasileiro, por meio de inventários, registros, vigilância, tombamento e desapropriação, além de outras formas de acautelamento e preservação. $O$ texto prevê ainda punição contra os danos e ameaças a esse patrimônio, que incluí, entre os bens materiais e imateriais, os documentos." 
As Leis Orgânicas municipais que estudamos, da mesma forma como a Constituição Federal não se referem apenas aos documentos de "valor histórico", ainda no capítulo "Da Cultura", determinam as Leis Orgânicas, reproduzindo o texto constitucional, "Cabe a administração pública, na forma da lei, a gestão da documentação governamental e as providências para franquear sua consulta a quantos dela necessitem".

Como vemos, a questão da documentação governamental é tratada na Constituição Federal e em decorrência disso, nas Leis Orgânicas municipais, que a reproduzem, como uma questão ligada à Cultura e não à Administração. Na introdução do livro O papel dos arquivos na administração e na política de planificação, de Jean-Jacques Valette (1993), Morris Rieger, então Secretário Geral Adjunto do Conselho Internacional dos Arquivos, afirma,

"No espírito do leigo, os 'arquivos' são tradicionalmente associados à idéia de 'cultura' e de 'erudição', e se considera daí que não têm quase ou nenhuma utilidade prática. À luz dessa compreensão, que é muito difundida, as autoridades, financeiras - tanto públicas quanto privadas têm naturalmente tendência a conceder uma prioridade muito pouco construtiva ao financiamento dos arquivos, que colocam na categoria de despesas de luxo."

É a visão culturalista do documento e do arquivo que se reproduz em uma cadeia, difícil de ser quebrada. Grande parte dos municípios ao criar seus Arquivos Públicos Municipais (muitas vezes ainda com a denominação "Arquivo Histórico") o fazem ligados às Secretarias ou Departamentos de Cultura acarretando as dificuldades sofridas posteriormente: o arquivo permanente fica dissociado dos arquivos correntes e do intermediário, não há fluxo regular dos documentos produzidos para o mesmo, a articulação com os vários setores da administração é dificultada pelo fato dos demais considerarem que esse arquivo é o da Secretaria da Cultura enviando para o 
mesmo, fragmentos, curiosidades, uma documentação tão desfigurada por eliminações sem critérios, que seu valor para pesquisa é prejudicado.

Esta situação foi bem diagnosticada por Schellenberg ${ }^{21}$, referindo-se ao Arquivo Nacional quando o mesmo era vinculado ao Ministério da Justiça,

"Estando o Arquivo Nacional sob a jurisdição do Ministério da Justiça e Negócios Interiores, é considerado pelo pessoal dos outros ministérios simplesmente como a instituição arquivística daquele ministério. (...) Assim, há atualmente urgente necessidade de reconhecer-se o Arquivo Nacional como a instituição arquivística central do Governo Federal do Brasil, bem como seu interesse em todas as ações governamentais que influenciam a eliminação de documentos públicos e, particularmente, sua autoridade para rever, do ponto de vista de seu valor de pesquisa ou histórico, os documentos cuja destruição foi proposta."

Atualmente o que se propõe é que o Arquivo Público do município, encabeçando o Sistema de Arquivos constitua um autarquia ou fundação pública ou fique subordinado ao Gabinete do Prefeito, se integrar a administração direta (Machado e Camargo, 1999). Justificam as autoras esta condição - semelhante a do Arquivo Nacional, hoje diretamente ligado a Casa Civil da Presidência da República - "pelo prestígio, eqüidistância e rapidez de comunicações, face à proximidade do órgão com a cúpula municipal. Avulta também, no caso, o fato de se tratar de instituição compelida, por sua missão de integração sistêmica, a manter relações com todas as unidades orgânicas da Prefeitura".

Assim, da mesma forma como em obediência à Constituição Federal, os municípios aprovaram suas Leis Orgânicas, devem em obediência à Constituição Federal e à Lei Federal $n^{\circ}$ 8.159/91, instituir seu Sistema de

21 Quando de sua estadia no Brasil, a convite do Arquivo Nacional, Theodore Schellenberg elaborou um relatório que apresentou a José Honório Rodrigues, seu Diretor na época. Este, relatório foi editado em 1960 pelo Arquivo Nacional com o título "Problemas arquivísticos do Governo Brasileiro". 
Arquivos e seu Arquivo Público Municipal. Ao mesmo tempo estariam estas unidades da Federação regulamentando o que estabelecem suas Leis Orgânicas quanto a gestão e o acesso à documentação governamental, possibilitando a consulta dos documentos públicos aos cidadãos e a todos os demais interessados.

Ainda quanto à competência dos Municípios, lembramos o artigo 30 da Constituição Federal de 1988 que determina:

I - legislar sobre assuntos de interesse local

II - suplementar a legislação federal e estadual no que couber.

Por outro lado também determina o mesmo art. 30 da Constituição Federal de 1988:

- ítem II, a competência de suplementar a legislação federal e estadual no que couber;

- ítem IX, a competência de promover a proteção do patrimônio histórico-cultural local, observada a legislação e a ação fiscalizadora federal e estadual. ${ }^{22}$

Nesse sentido, deve-se relatar a parceria entre o Arquivo do Estado de São Paulo e o Ministério Público Estadual na defesa e preservação do patrimônio arquivístico público do Estado de São Paulo. Essa parceria foi formalizada mediante a celebração de um Termo de Cooperação Técnica, em 30 de agosto de 2000, publicado no Diário Oficial do Estado em $1 .^{\circ}$ de setembro de 2000 .

Cabendo ao Arquivo do Estado atuar como órgão técnico consultivo do Ministério Público Estadual na área de arquivos, subsidiando instauração de inquéritos civis ou ações civis públicas, essa instituição encaminhou uma representação para que em cumprimento da legislação em vigor, as administrações de todos os municípios do Estado de São Paulo

\footnotetext{
${ }^{22}$ Grifo nosso.
} 
institucionalizassem seus Arquivos Públicos, implantando a gestão de seus documentos também prevista por lei.

Um trabalho conjunto tem sido realizado entre o Arquivo Público do Estado de São Paulo e as Promotorias de Justiça, especialmente as de defesa da cidadania e do meio ambiente, considerando os direitos difusos de toda a coletividade, como o direito à informação e à memória. ${ }^{23}$

Estabelecidos os marcos legais com relação aos arquivos públicos e particularmente aos arquivos públicos municipais e as competências e responsabilidades do município com relação aos mesmos, trataremos a seguir dos documentos públicos nos municípios do Grande ABC.

${ }^{23}$ BERNARDES, Ieda Pimenta (et al). Políticas Municipais de Arquivo: Estratégias e Perspectivas. Texto apresentado no I Encontro Paulista sobre Gestão Documental Pública: por uma política municipal de arquivos. 24/10/2003, promovido pelo Sistema de Arquivos do Estado de São Paulo-SAESP, Arquivo do Estado de São Paulo e Secretaria de Cultura do Estado de São Paulo. 


\section{2 - Documentos públicos e sua custódia nos municípios do Grande ABC}

Documentos de arquivo são aqueles que, produzidos e/ou recebidos por uma pessoa física ou jurídica, pública ou privada, no exercício de suas atividades, constituem elementos de prova ou de informação. Formam um conjunto orgânico, refletindo as atividades a que se vinculam, expressando os atos de seus produtores no exercício de suas funções. Assim, a razão de sua origem ou a função pela qual são produzidos é que determina a sua condição de documento de arquivo e não a natureza do suporte ou formato.

Portanto, documentos públicos de arquivo são todos aqueles que, de qualquer suporte ou formato, são produzidos ou recebidos por um órgão governamental na condução de suas atividades. São também documentos públicos os produzidos e/ou recebidos por instituições de caráter público e por entidades privadas responsáveis pela execução de serviços públicos. No caso do município constituem documentos públicos de arquivo, os produzidos e acumulados pelos poderes executivo e legislativo no exercício de suas funções, com valor de prova ou informação. Neste trabalho optamos por pesquisar os documentos públicos relativos ao Poder Executivo municipal.

Como afirma Ramon Alberch Fugueras (1999) “...las Administraciones Públicas, son el paradigma de la producción de documentos y de grandes archivos porque han de dejar constancia documentada de todas y de cada uma de sus actuaciones".

Isto quer dizer que não há administração sem documentos, e no caso das administrações públicas, estes assumem outras dimensões além das administrativas, pois estas devem prestar contas de seus atos aos cidadãos que servem e aos outros poderes. Estes registros documentais constituem também fontes para a história e a memória destas instituições e da relação das mesmas com os cidadãos com os quais se relacionam. Registram suas 
demandas, reivindicações, protestos, e as ações do Estado como resposta aos mesmos, sendo a tarefa arquivística segundo Terry Cook (apud BELLOTO,1998) "preservar a evidência documentada da governança da sociedade, não apenas da atividade governante dos governos." Sendo que por governança, explicita Bellotto, "se entende a trama, isto é, tudo o que possa comprovar a interação entre cidadão e Estado, o impacto do Estado na sociedade e as funções e atividades da sociedade em si mesma; por governo, compreende-se as estruturas sustentadoras e a ação burocrática".

Entretanto, não existe nos sete municípios que constituem o Grande ABC uma instituição arquivística pública, um Arquivo Público Municipal responsável pela gestão, recolhimento, preservação dos documentos produzidos pelos poderes públicos municipais e pelo acesso a esta documentação.

Mas, como em todos eles há produção e circulação de documentos públicos, procuramos identificar e caracterizar os responsáveis pela guarda desta documentação pública municipal.

Estas informações foram obtidas através da pesquisa na legislação dos municípios, de questionários de coleta de dados enviados às prefeituras (Secretarias de Administração e Governo, Serviços de Arquivo) e, após o recebimento dos mesmos, de visitas aos setores para esclarecimentos de algumas das respostas dadas aos questionários 0 que permitiu complementar as informações, com as declarações dos funcionários e observações "in loco" dos locais de guarda. Aqui também tivemos a percepção das diferenças quanto ao acesso aos documentos e informações nas várias administrações. Com exceção da Secretaria da Administração de Diadema, todas as outras responderam aos informes solicitados. As informações que possuímos deste município decorrem de consultas a documentos administrativos e observações "in loco" no período em que trabalhamos no Serviço de Arquivo (2002-2003), matérias de jornais e depoimentos de funcionários. 
Quanto à legislação municipal pode ser consultada no "site" das Câmaras de Santo André, São Bernardo, Diadema e Mauá. Em São Bernardo solicita-se a lei por e-mail no site da Câmara Municipal. No caso da lei que estabelece a estruturação administrativa, cargos e salários, como é de 1973 com inúmeras modificações e está codificada em vários volumes, foi-me pedido que agendasse um horário para consulta com a bibliotecária da Câmara. Em Mauá, a legislação está no site da Câmara, mas a forma como foi processada a digitalização dificulta a pesquisa no caso de longas tabelas que originalmente na horizontal, foram colocadas no site na posição vertical. Em São Caetano não é possível à população ou a qualquer outra pessoa interessada, consultar as leis da cidade na Câmara Municipal, é necessário ir ao Cram-Centro de Atendimento Rápido ao Munícipe e solicitar uma cópia. Conforme orientação da funcionária do Serviço de Protocolo solicitei cópia da Lei $n^{\circ} 1489 / 96$ e suas alterações pagando a taxa de $R \$$ 3,67 ao dar entrada no pedido. Quando fui retirar tive a surpresa de descobrir que a cópia ficara em $R \$ 172,04$, já que a lei sofreu inúmeras modificações com o tempo e a administração cobra cada folha reproduzida. Por outro lado, em Ribeirão Pires, a Câmara não possui biblioteca, mas pude sentar na sala das advogadas da instituição e consultar a legislação pretendida e em Rio Grande da Serra - o menor e mais carente de recursos dos municípios da região - a funcionária da Câmara colocou-me em contato com a Secretaria de Assuntos Jurídicos, que enviou a legislação por e-mail. Nas Câmaras Municipais é possível consultar apenas as leis, os decretos devem ser pesquisados nas Bibliotecas das Secretarias de Assuntos Jurídicos, que existem em alguns municípios.

Não estamos tratando neste trabalho dos arquivos do poder legislativo, ainda que estes sejam também produtores de documentos públicos de arquivo nos municípios, previstos pela Lei $n^{\circ} 8.159 / 91$. Mas o que se percebe aqui, da pesquisa a um dos documentos produzidos pela instituição é que a obrigação de dar acesso aos mesmos, prevista não só 
pela Constituição atual como pela "Lei de Arquivos", não merece a observância devida em todos o municípios.

Em Santo André e São Caetano as informações foram prestadas pelos responsáveis pelos Serviços de Microfilmagem e Arquivo separadamente. Em Santo André, são dois serviços separados, ambos vinculados a Gerência de Apoio Administrativo da Secretaria de Administração. Em São Caetano, o Serviço de Protocolo e Arquivo está subordinado à Diretoria de Administração e o de Microfilmagem à Diretoria de Finanças. Em São Bernardo, a Seção de Arquivo Central compreende também o Serviço de Microfilmagem, ambos vinculados a Secretaria de Governo.

Em Diadema, o Serviço de Arquivo e Microfilmagem ${ }^{24}$ está subordinado ao Departamento de Serviços Gerais e Documentação da Secretaria da Administração. Nesse município, assim como em Mauá, Santo André, Ribeirão Pires e Rio Grande da Serra, o Arquivo faz parte da estrutura organizacional da Secretaria da Administração, está subordinado a uma chefia que também se encarrega dos chamados "serviços gerais": zeladoria, telefonia, cemitério.

Em Mauá, Ribeirão Pires e Rio Grande da Serra, nos Serviços de Protocolo e Arquivo não existe ou existiu um serviço de microfilmagem de documentos.

Apesar de algumas variações quanto à denominação, Arquivo Central em Santo André e São Bernardo, Seção de Protocolo e Arquivo em São Caetano e Mauá, Serviço de Arquivo e Microfilmagem em Diadema ${ }^{25}$, esses serviços se preocupam com a guarda dos processos administrativos ${ }^{26}$,

\footnotetext{
${ }^{24}$ Apesar da denominação não existe atividade de microfilmagem neste serviço ou ligado a ele.

${ }^{25}$ A expressão "arquivo morto" entretanto é usada correntemente para esses órgãos e a relação dos vários setores da Administração com este Arquivo Geral ou Central em geral é de depósito

26 Processo ou expedientes são conjuntos de documentos, que materializam atuações sequênciais e procedimentos e consubstanciam uma decisão da Administração a respeito de uma matéria. (Oliveira, 2002).
} 
autuados $^{27}$ em um Serviço de Protocolo, responsável também pelo acompanhamento de sua tramitação. O único conjunto documental que as administrações conservam desde sua emancipação política são os processos administrativos custodiados por esses serviços ${ }^{28}$. Na verdade, mesmo com relação a estes documentos não se pode afirmar que a totalidade deles esteja conservada por vários motivos: processos que foram retirados de um município e encaminhados a outro; processos que foram eliminados por determinação de normas da administração, eliminação "natural", dadas as condições inadequadas de guarda e processos "extraviados", saíram do Serviço de Arquivo e não retornaram, pois não há este tipo de controle em todos os municípios ( muitos só dão pela falta do processo quando é solicitado e, aí, verificam que saiu daquele órgão e não retornou).

Com relação à documentação produzida, são poucos e fragmentados os documentos de outras secretarias que se encontram nos Serviços de Arquivo. O que se guarda neles, além dos processos administrativos, são em geral documentos das secretarias-meio, ou das secretarias que funcionam próximas a Secretaria da Administração. Assim encontramos nesses serviços geralmente documentos relativos a Finanças, ao Governo, ao Gabinete do Prefeito. Os documentos das secretarias-fim, Educação, Saúde, Habitação, não estão no Serviço de Arquivo, nem existe um Arquivo Central dos mesmos nesses municípios.

O caso do município de Diadema é exemplar. Como nos seus primórdios Diadema era uma espécie de bairro rural da vila e depois município de São Bernardo, encontram-se no Fundo Câmara e Intendência de São Bernardo, que está no Museu de Santo André, algumas informações

\footnotetext{
27 "Autuar um processo consiste em registrar, ordenada e regularmente, o conjunto formado por requerimentos, solicitações ou papéis que envolvam decisões administrativas" (Oliveira, 2002)

${ }^{28}$ Segundo informações destes mesmos serviços, a maior parte deles custodia processos desde os anos 40 ou 50 do século passado.
} 
referentes a seus núcleos de povoamento mais antigos, particularmente Piraporinha.

A partir de 1944, com a emancipação de São Bernardo, os antigos núcleos de povoamento da região, Eldorado, Piraporinha, Vila Conceição passam a pertencer a esse município, constituindo em 1958 o Distrito de Diadema. As referências a Diadema passam a ser encontradas nos arquivos de São Bernardo: processos e outros documentos administrativos do poder executivo, atas da Câmara Municipal. Estes documentos estão em parte no Serviço de Memória e Acervo de São Bernardo do Campo (mapas e processos administrativos recolhidos pelo antigo SDHL-Serviço de Documentação e História Local) subordinado à Seção de Memória e Patrimônio Histórico e Cultural e à Secretaria de Educação e Cultura, no Serviço de Banco de Dados da Divisão de Estatística e Cadastro da Secretaria de Administração (mapas e plantas), na Seção de Arquivo Central (processos microfilmados) vinculado a Secretaria de Governo.

Com a emancipação em 1958 , e a posse do $1^{\circ}$ prefeito e Câmara Municipal em $1^{\circ}$ de janeiro de 1960 , o município de Diadema passa a produzir e acumular sua própria documentação pública. A Lei 05/60 dispunha sobre a organização dos serviços da Prefeitura criando os seguintes órgãos:

I - Secretaria

II - Contadoria

III - Lançadoria

IV - Tesouraria

V - Serviço de Viação e Obras Públicas

Entre as atribuições do Secretário-Contador estava "organizar e dirigir o protocolo, arquivo de livros, de correspondência, processos e outros papéis."

Mas o Protocolo e o Arquivo só foram implantados efetivamente na $2^{\mathrm{a}}$ gestão municipal, quando a lei $186 / 64$ criou a Diretoria Administrativa constituída por vários serviços, entre eles a Secretaria que incluía: 
a) Protocolo

b) Controle do andamento de processos

c) Arquivo Geral

d) Elaboração, recepção e arquivamento de correspondência

e) Documentação e preparo de processos

Apesar de ter apenas 45 anos muito pouco resta da documentação produzida pelas administrações que se sucederam desde 1960. O Serviço de Arquivo e Microfilmagem é uma espécie de Arquivo Central com a custódia dos processos administrativos e da documentação avulsa para ele encaminhada. A consulta às Relações de Remessa guardadas por esse órgão e ao livro de Atas de Eliminação de Documentos mostra que a maior parte dos documentos avulsos encaminhados para o mesmo foram fragmentados, os que restam estão desde 1997 em um depósito no Bairro Eldorado, um galpão em que as condições precárias quando da transferência dos documentos sofreram acelerado processo de deterioração, assim como os documentos aí depositados. ${ }^{29}$

Para dar lugar à Guarda Municipal, o Arquivo Geral, que guarda os processos administrativos do poder executivo desde a emancipação do município ${ }^{30}$ até os que podem ser considerados de idade intermediária, foi transferido do centro da cidade em 2001, para dependências do antigo Instituto Eldorado, um edifício construído nos anos 60 para abrigar um hospital psiquiátrico e adquirido pela prefeitura em 1996.

As condições do local para guarda da documentação são extremamente inadequadas, o bairro do Eldorado fica à beira da Represa Billings, uma área de mananciais, e é extremamente úmido. As salas que abrigam os processos administrativos internos e externos e outros

\footnotetext{
${ }^{29}$ O informativo Info-Serv (junho/2004), em breve nota, informou que tem sido feita por funcionários do Serviço de Arquivo e da Gráfica da prefeitura (que funciona junto ao mesmo e com a mesma chefia), a higienização e acondicionamento dos documentos que restaram.

${ }^{30}$ Existem neste local processos anteriores a emancipação, do período em que Diadema pertencia a São Bernardo e que foram remetido pelo Arquivo de São Bernardo para o de Diadema, confome decisão da Comissão de Avaliação de Documentos de São Bernardo, assunto tratado mais detalhadamente no ítem 4.2
} 
documentos, a maior parte documentos da Secretaria de Finanças e do Gabinete do Prefeito, não têm forro, as portas e as venezianas das janelas foram retiradas por iniciativa de funcionários do Serviço de Arquivo quando de sua transferência, porque ainda não havia sido providenciada iluminação para as salas, como resultado disso agora a documentação está exposta à sujeira trazida pelo vento, à forte incidência dos raios solares e ao calor. Os processos mais volumosos, chamados "processos-balcão" não são acondicionados em caixas e sim colocados diretamente nas estantes de madeira, sofrendo mais ainda os efeitos da poeira e dos raios solares. Não existem aparelhos que possam minimizar a umidade e o calor. As estantes de madeira do galpão que guardavam os documentos avulsos foram trazidas para acomodar os processos administrativos transferidos, provocando maior desorganização e dano aos documentos que estavam neste outro local, que passaram a ser amontoados no chão.

Não há índices, listagens ou qualquer instrumento de pesquisa que permitam recuperar as informações sobre os acervos guardados no que se refere à documentação avulsa, apenas as relações de remessa da documentação que foi encaminhada, e boa parte dos documentos chegaram sem relação de remessa.

Quanto aos processos, estão no sistema (informatizado), disponíveis para pesquisa os processos a partir de 1993. Para os processos anteriores, a busca é feita nos fichas de papel. Mesmo com relação aos que foram colocados no sistema há dificuldades, acontece de não corresponder o que está no sistema com o ano e o número da caixa. Os funcionários nesta gestão tem procurado conferir estes dados com o conteúdo das caixas. Além disso o sistema também está perdendo dados o que dificulta a pesquisa. $A$ forma de arquivamento é numérico-cronológica. Há uma relação de 251 assuntos, que deve ser utilizada pelo Serviço de Protocolo quando o processo ou expediente é aberto, apesar que muitas vezes o funcionário 
prefere lançar com o código 80 (outros) ou 251 (providências). Mesmo esta espécie de classificação se perde no processo de arquivamento.

Os funcionários do Serviço se preocupam com o documento "processo administrativo", não há maior interesse na guarda e conservação dos outros documentos, com exceção dos documentos encaminhados pelo Gabinete do Prefeito. A partir da elaboração de Tabelas de Temporalidade ${ }^{31}$ dos vários departamentos da Secretaria de Finanças, na gestão 1998-2000, os documentos enviados por estes setores que foram classificados como permanentes passaram a ser guardados no mesmo prédio que os processos, mas documentos com a mesma tipologia que estavam no galpão já mencionado foram separados para fragmentação, por exemplo, os primeiros livros-caixa da prefeitura.

A ausência de critérios e/ou a dificuldade para observá-los, quanto a guarda de documentos de caráter permanente, também se observa nos exemplos seguintes. Entre os documentos identificados como permanentes, uma caixa com a etiqueta Documentos Históricos chamou-nos a atenção. No interior dela havia antigos exemplares de um informativo da Associação dos Funcionários Públicos da cidade e várias páginas datilografadas sem identificação relatando acontecimentos da cidade. Percebemos que eram cópias de uma parte do livro "Diadema: Sua História”(1988), de autoria de Sylvia Esquível, memorialista, viúva do primeiro prefeito da cidade.

Por outro lado, um Memorando Interno do dia 03 de agosto de 1990, do Diretor do Departamento de Governo encaminhava ao Serviço de Arquivo "documentos para serem arquivados definitivamente, conforme relação em anexo". O documento relacionava 72 caixas com os "clippings" de janeiro de 1983 a dezembro de 1988, produzidos pelo Departamento de Imprensa, subordinado ao então chamado Departamento de Governo.

\footnotetext{
${ }^{31}$ Sobre a elaboração destas Tabelas trataremos detalhadamente no ítem "Iniciativas de Gestão".
} 
À respeito dos "clippings" afirma Lopes (1996) que estes recortes e cópias de partes de publicações podem constituir dois conjuntos documentais:

“a) os que se referem diretamente às atividades desenvolvidas pela pessoa ou organização;

b) os que servem de apoio às atividades desenvolvidas.

No primeiro caso, defende-se aqui, trata-se de documentos de arquivo.

Se uma organização faz ou manda fazer, por exemplo, o clipping, selecionando informações dadas pela imprensa, sobre as atividades que desenvolve ou osinteresses em que está envolvida, não há dúvida, trata-se de informação arquivística. Há uma seleção, uma atribuição, um olhar sobre documentos produzidos por outrem."

Segundo o autor, com o passar do tempo estes documentos podem ser avaliados como qualquer outro documento de arquivo.

Tivemos oportunidade de observar algumas das caixas que sobreviveram às condições em que se encontravam. O Departamento de Imprensa selecionava e guardava tudo o que era publicado na imprensa local, regional e estadual sobre o que ocorria na cidade, no estado, no Brasil naquela época. Muitos do jornais utilizados não existem mais, com o Jornal do Planalto e a Folha Metropolitana, dedicados a matérias da região. Estes "clippings" correspondiam ao período final da gestão Lauro Michels, e a vitória de Gílson Menezes, primeiro prefeito eleito do Partido dos Trabalhadores no Brasil. A seguir cobriam todo seu governo, as experiências de gestão da primeira prefeitura petista, suas relações com outras forças políticas na cidade e fora dela, e o pano de fundo em que isto acontecia, o período da redemocratização do país, e ainda a eleição de seu sucessor e os primeiros anos de seu governo.

$\mathrm{Na}$ época em que esses documentos foram enviados ao Arquivo ainda vigorava a prática do titular do departamento manifestar-se sobre sua 
conservação ou destruição. Mas as condições de guarda desses documentos e o desinteresse pela conservação dos mesmos provocou a destruição da maior parte.

Quanto ao interesse mencionado pelo documento "processo administrativo", o Serviço não tem, entretanto, o controle sobre os processos que são requisitados pelos órgãos da administração e não retornam. Apenas quando há uma solicitação e é feita a pesquisa, a não devolução é percebida e o processo é cobrado. Segundo os funcionários o sistema atual não permite este controle, mas um controle paralelo poderia ser feito utilizando o Word ou o Excel já instalados.

Também não são feitas estatísticas sobre as demandas ao serviço: quantos processos são solicitados, os setores que mais demandam, etc.

Nem todos os processos estão neste "Arquivo Central", por exemplo, os processos de loteamento dos bairros desde 1960 estão no Serviço de Cadastro, da Secretaria de Planejamento, em más condições de acondicionamento e guarda, o Serviço de Regularização Fundiária, ligado Assistência Judiciária e à Secretaria de Assuntos Jurídicos guarda a documentação relativa à concessão do direito real de uso e os processos referentes à regularização fundiária.

A Secretaria da Habitação guarda quantidade significativa de séries documentais referentes a pré-urbanização e urbanização de favelas, produzidos desde o início dessas atividades em 1983. Antigos funcionários avaliando a relevância desta documentação propuseram a criação de um Setor de Memória no organograma desta Secretaria. Não consideram, assim como os funcionários do Serviço de Arquivo, que o lugar desta documentação é o Arquivo da prefeitura.

As Secretarias da Educação e da Saúde, assim como outras secretarias, não enviam para o Serviço de Arquivo nem seus documentosmeio, nem seus documentos-fim. É como se cada Secretaria fosse um 
organismo independente e não partes de um sistema, uma organização, a administração municipal, a Prefeitura Municipal de Diadema.

Outro setor da prefeitura abrigava uma parcela de documentos de caráter arquivístico da prefeitura: o Centro de Memória de Diadema, serviço que funciona desde 1993 no Departamento de Cultura, apesar de não ter sido regulamentado até hoje: existe de fato, mas não de direito. Este serviço custodiava grande parte da documentação produzida e acumulada pelo Departamento de Comunicação, órgão da Secretaria de Governo ${ }^{32}$ : todos os vídeos produzidos de 1987 a 2000, negativos e reproduções fotográficas produzidos por este departamento a partir de 1983, além da coleção do Jornal da Cidade e do Jornal do Pé na Rua, também produtos deste departamento. Os "clippings" produzidos pelo Departamento de Comunicação durante a últimas duas gestões também estavam no Centro de Memória para o aproveitamento das matérias que se relacionavam com as linhas de pesquisa do Centro de Memória.

Como ocorre em outros municípios nem a Secretaria de Governo, nem o Departamento de Comunicação tinham clareza de que estes documentos, eram documentos públicos arquivísticos deste órgão, e o Centro de Memória os recebia, particularmente os vídeos e fotografias, porque era sua política conforme documento datado de 1993 constituir o maior banco de imagens da cidade, ciente do poder de guardar imagens de um município que cresceu rápida e desordenadamente, com a transformação da Vila Conceição dos anos 20 , em que predominavam chácaras ao município atual que tem a segunda maior densidade demográfica do Brasil em seus $30 \mathrm{~km}^{2}$.

O Centro de Memória também guardava documentos de outros setores da administração, por exemplo, documentos textuais e fotos da Lira de Diadema (1968-1997), agremiação musical ligada à Secretaria de Educação, Cultura e Esportes e outros documentos do Departamento de Cultura, projetos, relatórios, folders, convites, programação cultural, cartazes

\footnotetext{
${ }^{32}$ Em 2004, o Departamento de Imprensa passou a denominar-se Secretaria de Comunicação.
} 
de eventos e ainda fragmentos das primeiras administrações, por exemplo, o original do relatório da primeira administração enviado à Câmara pelo prefeito Evandro Caiaffa Esquível, original do relatório do Diretor de Saúde, com o diagnóstico e as ações de seu Departamento, de 1973 a 1976, encaminhados por ele ao Prefeito Ricardo Putz.

Isto até a madrugada do dia 03 de julho de 2003, quando um incêndio destruiu grande parte dos acervos que aguardavam em uma sede precária e provisória, a reforma do prédio onde se instalaria definitivamente o Centro de Memória.

Outro órgão, fora da estrutura organizacional da prefeitura, guarda documentos administrativos (cópias, em sua maioria) do município de Diadema: trata-se do Idem-Instituto Diadema de Estudos Municipais. Esse Instituto requereu sua inscrição municipal em seis de agosto de 1996, cadastrando seu ramo de atividade como "pesquisa e desenvolvimento de ciências sociais e humanas", sendo sua abertura no dia 06 de dezembro de 1996. O folder institucional afirma que este teria como objetivo primordial "a contribuição através de estudos, análises e projetos, para o desenvolvimento das relações entre poder local, democracia e cidadania, na busca de uma sociedade mais justa e de uma vida melhor" e que seria "um importante instrumento de pesquisa e avaliação política" para entre outras coisas "estimular o conhecimento sobre a realidade socio-econômica, política e cultural da cidade" Na verdade, a partir do momento que se configurou a vitória de um prefeito de oposição ${ }^{33}$, houve a preocupação de guardar relatórios, projetos, programas, atas, estudos e outros documentos significativos particularmente daquela gestão e mesmo da administração anterior, a qual este prefeito pertencera. Essa medida indica que os administradores sabem perfeitamente a importância destes documentos para a elaboração de futuros projetos e planos de governo, e mesmo para a memória da administração, daí o interesse em conservá-los e não tendo

\footnotetext{
${ }^{33}$ A ata da Assembléia Geral de constituição e fundação é de 31/7/1996.
} 
instituído um sistema responsável e confiável a quem deveriam ser encaminhados estes documentos, temem que estes se percam ou que um opositor possa descartá-los, inviabilizando o acesso aos mesmos e às informações neles registradas.

Um precedente destas ações já ocorrera quando os documentos relativos à administração da prefeita Luiza Erundina (São Paulo, 1989-1992), foram encaminhados para a custódia do Cedem-Centro de Documentação e Memória da UNESP. Segundo o Guia do Cedem (1996, p. 43 e 44), o Cedesp-Centro de Documentação e Estudos da Cidade de São Paulo, transferiu sob custódia a documentação acumulada durante essa administração através de convênio firmado em 1995. Nesse guia a documentação é descrita como Fundo da Administração Popular Luiza Erundina, colecionada pelo Cedesp, criado em 1993 pela ex-prefeita de São Paulo para preservar e colocar à disposição dos pesquisadores e demais interessados em questões de políticas públicas municipais e gestão urbana as informações sobre as experiências acumuladas em seu governo.

Esta fragmentação da documentação pública arquivística, que observamos mais detalhadamente em Diadema, ocorre também em outros municípios. A Fundação Pró-Memória de São Caetano tem em seu acervo negativos e reproduções fotográficas produzidas pelo Departamento de Comunicação Social, plantas de todo o arruamento da cidade, lote por lote, transferidas pela Seção de Cadastro Fiscal, atas das sessões e processos da Câmara Municipal, entre outros documentos. O Museu de Santo André guarda o Fundo Câmara e Intendência de São Bernardo do Campo, relatórios da administração, mapas e plantas, bem como fotografias produzidas pela Assessoria de Comunicação. O mesmo ocorre em São Bernardo do Campo, onde o Serviço de Memória e Acervo custodia livros contábeis da administração pública a partir da segunda metade dos anos 40 , processos administrativos da Prefeitura entre 1929 e 1944 e 1945 e os anos 60, fotografias produzidas pelo Departamento de Comunicação, entre outros. 
Em Ribeirão Pires, o Museu Municipal e o Centro de Apoio Técnico ao Patrimônio de Ribeirão Pires, também conservam em seu acervo fragmentos da documentação pública: livros-caixa de 1954 a 1950, contratos de locação, entre 1955 e 1965, e um significativo acervo fotográfico.

Muitas vezes o recolhimento foi uma ação salvacionista, as instituições recolheram documentos públicos de arquivo do poder executivo ou legislativo para que não fossem destruídos ou se perdessem. Outras vezes, a ação foi deliberada, o recolhimento foi feito para constituir o acervo da instituição.

Nesses locais, perdido o contexto de produção, separados dos outros documentos produzidos e que deviam fazer parte do mesmo fundo, são tratados como coleções e perdem grande parte de seu potencial informativo. Ignora-se o princípio da organicidade, segundo o qual, "as relações administrativas orgânicas se refletem nos conjuntos documentais. A organicidade é a qualidade segundo a qual os arquivos espelham a estrutura, funções e atividades da entidade produtora/acumuladora em suas relações internas e externas" (Bellotto, 2002).

Buscamos na legislação que criou estas instituições e em seus documentos institucionais (guias, relatórios, folders de apresentação) saber de sua origem e funções, buscando a relação com a constituição de seu acervo. Aqui também contamos com o depoimento de funcionários que trabalharam nestes órgãos.

$\mathrm{Na}$ maior parte dos municípios essas instituições de memória e história e depositárias de documentos, estão ligadas ao Departamento de Cultura (e a Secretaria de Educação, Cultura, Esportes) ou a Secretaria de Cultura. São exceções, o Museu Municipal de Ribeirão Pires, vinculado ao Gabinete do Prefeito e a Fundação Pró-Memória de São Caetano, que é uma autarquia. 
O Serviço de Memória e Acervo ${ }^{34}$, funciona nas instalações e detém o acervo do SDHL-Serviço de Documentação e História Local, que tem sua origem ligada à Sala São Bernardo, constituída após o recolhimento de documentos sobre a história da cidade provenientes de uma gincana organizada pela Divisão de Bibliotecas, Documentação e Informática. Em 1981, passaram a fazer parte desse acervo os processos administrativos a partir de $1945^{35}$. O Serviço de Documentação só foi criado pela Lei Municipal $\mathrm{n}^{\circ} 3.104 / 88^{36}$, reunindo os trabalhos de pesquisa iniciados com Sala São Bernardo e o acervo já existente.

O Decreto $n^{\circ}$ 9.649, de 31 de agosto de 1988, demonstra que orientou a criação do Serviço a concepção de que o mesmo seria uma espécie de "arquivo histórico" da prefeitura de São Bernardo. Nele aparecem como atribuições do Serviço de Documentação e História Local:

I - Levantar, analisar e destinar a documentação arquivística visando a organização da coleção de valor histórico e preservação da memória administrativa e social.

II - Prestar orientação técnica aos órgãos geradores de documentos de arquivo.

III - Participar do processo de avaliação e destinação de documentos gerados pela Administração Pública Municipal.

IV - Propor políticas de acesso aos documentos públicos.

VI - Informar e fornecer subsídios aos administradores, pesquisadores e público em geral com base nos documentos custodiados.

\footnotetext{
${ }^{34}$ Em 2001, o SDHL-Serviço de Documentação e História Local, foi dividido em: Serviço de Patrimônio e Acervo e Serviço de Patrimônio Histórico.

${ }^{35}$ Estes dados constam do folder do SDHL, Memória da Cidade-São Bernardo do Campo(1989-1992). Já no periódico, Domingo em São Bernardo, 15/12/85, p. 2 aparece a informação de que estes "35 mil processos administrativos estavam para ser incinerados e por isso foram trazidos".

${ }^{36}$ Quanto ao Quadro do Pessoal, esta lei estabelecia que o Encarregado de Serviço de Documentação da História Local devia ser um bibliotecário com especialização em arquivo histórico (sic).
} 
Outros ítens estabeleciam, "a proteção ao patrimônio documental e cultural; a preservação da memória do município; o cadastro de bens culturais de interesse da comunidade."

Também percebemos o equívoco com relação às funções do Arquivo Municipal no folder institucional da Fundação Pró-Memória (1993-1996) declarando que seu "Centro de Documentação abriga também o núcleo do Arquivo Público Municipal".

Da mesma forma, um relatório do Centro de Memória de Diadema ${ }^{37}$, menciona no item 7 - Outros Trabalhos em que o Projeto Memória participou, "letra c) Arquivo Municipal - participação na Comissão de Avaliação do Arquivo Municipal e incorporação da sua documentação permanente ao Centro de Memória". Na verdade, essa Comissão de Avaliação teve dificuldades para ser constituída e não chegou a iniciar seus trabalhos, como veremos no capítulo que trata da Avaliação de Documentos, mas o documento citado demonstra o interesse da instituição em parte da documentação pública arquivística do município e do equívoco que havia na época entre o papel de um Centro de Memória e de um Arquivo Municipal.

No que respeita aos Serviços de Arquivo, muitas vezes o critério para a guarda é a proximidade, "guardamos documentos das secretarias que ficam próximas, aqui no Paço". Mas não se consideram responsáveis por esta documentação, apenas cedem espaço. Vigora a idéia de que cada secretaria deve se responsabilizar por seus documentos mesmo não existindo outro setor dentro do organograma do poder executivo que seja encarregado da documentação.

Como não há uma política arquivística de gestão de documentos, as atividades de classificação e avaliação arquivísticas responsáveis pelo controle da documentação não são realizadas. Assim, não existe um quadro

\footnotetext{
${ }^{37}$ Documento "Projeto Memória da Cidade, $1^{\circ}$ semestre de 1994", Acervo Centro de Memória de Diadema.
} 
de classificação ${ }^{38}$ dos documentos produzidos e acumulados, nem tabelas de temporalidade ${ }^{39}$ com o estabelecimento da destinação dos mesmos. Quanto à classificação nos arquivos correntes, variam de acordo com o entendimento dos funcionários dos setores as formas de classificação, ordenação e guarda. Lopes (1996) chama a atenção para os métodos empíricos de arquivamento e recuperação dos documentos e informações,

"é ingênuo acreditar que o senso comum não é capaz de organizar informações e arquivos. De modo geral, a experiência demonstra que as organizações conseguem funcionar com métodos completa ou parcialmente empíricos. A presença de "instrumentos de pesquisa" vivos, a prática da consulta direta feita pelos funcionários envolvidos, o uso da memória coletiva, a prática de não se remeter a casos passados, a capacidade de improvisar, entre outros expedientes, supre a falta de planejamento da gestão."

Segundo o autor ocorre a percepção de ineficiência, da demora para se gerir a informação, entretanto raramente se percebe que estes problemas decorrem "do reinado do senso comum na efetivação de práticas arquivísticas".

Ainda com relação à classificação, os processos administrativos são em geral classificados de forma numérico-cronológica, com todos os problemas decorrentes deste sistema.

Nos municípios de Santo André, São Bernardo, São Caetano e Diadema houve algumas tentativas de avaliação de documentos que estudaremos em detalhe em outro capítulo. Nos demais, não encontramos referências a essas iniciativas.

\footnotetext{
${ }^{38}$ Classificação é a sequência de operações que de acordo com as diferentes estruturas, funções e atividades da entidade produtora, visam distribuir os documentos de um arquivo (Camargo e Bellotto, 1996,)

${ }^{39}$ Tabela de Temporalidade é instrumento de destinação aprovado por autoridade competente, que determina prazos para transferência, recolhimento, eliminação, e reprodução de documentos (Camargo e Bellotto, 1996)
} 
Uma resposta freqüente dos funcionários, quando perguntados sobre o destino dos documentos produzidos, é: "São descartados conforme a lei dos cinco anos". Persiste ainda a concepção e a prática, já observadas por Soares (1998), "os administradores desavisados e o grande público associam a idéia de guarda dos documentos de arquivo à validade dos mesmos como prova legal e à prescrição quinqüenal". Ainda sobre a prescrição cita um levantamento feito pela Fundap-Fundação do Desenvolvimento Administrativo para a Vasp-Viação Aérea São Paulo: no levantamento de atos que dispõem sobre prazos de prescrição, decadência e outros na área de comércio, finanças, transportes, previdência, etc., a Fundap ao arrolar 69 atos, analisou mais de 200 artigos cujos prazos de prescrição variam entre 32, 30, 20, 10, 5, 4, 2 e 1 ano, sendo que a maior freqüência é a qüinqüenal, que ocorre 36 vezes.

Além disso há a associação feita com a fiscalização do Tribunal de Contas referente aos últimos 5 anos.

Há que se considerar, entretanto, que além de outros prazos prescricionais, que variam conforme o documento, mesmo depois de esgotado o valor legal, outros valores devem ser considerados que justificam a não eliminação dos documentos.

Se funcionários desses setores procuram encaminhar a documentação, em geral documentos de atividades-meio, para os Serviços de Arquivo, encontram uma série de obstáculos, sendo a alegação mais freqüente a de falta de espaço.

Os Serviços de Arquivo em geral funcionam em locais adaptados, onde os documentos sofrem risco de destruição pelas condições ambientais, ausência de dispositivos de segurança, mau acondicionamento. Ficam em garagens municipais, junto a entrepostos de vendas de alimentos perecíveis ("sacolões" de frutas e verduras), ocupam parte das instalações de um antigo hospital psiquiátrico. Mesmo quando estão no Paço Municipal, o espaço é insuficiente e inadequado para sua guarda. A exceção é São Bernardo do 
Campo, onde os Serviços de Arquivo e o de Microfilmagem funcionam em instalações construídas recentemente ocupando uma área de 1900 metros quadrados, sendo 900 metros quadrados de área construída. ${ }^{40}$

$\mathrm{Na}$ verdade, originalmente, os Serviços de Arquivo funcionavam nas instalações do Paço Municipal, assim como o Setor de Protocolo. Mas em vários municípios foi transferido para dar lugar a outros serviços, já que a visão do arquivo para a administração é a de um depósito que não precisa ocupar uma área nobre.

São bastantes ilustrativas dessa afirmação as palavras do Secretário de Administração de Diadema, no Diadema Jornal, de 15 de abril de 2001, p.A-3. A matéria tem o título "Prefeitura 'resgata' processos desaparecidos", nela o secretário fala de processos internos não localizados, afirmando "Temos problemas com processos antigos, como um que a justiça pediu e trata de uma prestação de serviço do período 1992/1993, que já foi para o arquivo morto e não encontramos." Mais adiante, aparece o subtítulo, "Armazenamento de toda papelada é o grande problema da prefeitura", onde o secretário afirma que "são utilizados dois endereços para o arquivamento de processos, os chamados "arquivos mortos", que estão abarrotados de pastas e documentos." Declara ainda a intenção de transferir e concentrar todo o "arquivo morto" em um local apenas, o prédio do Eldorado, e que a área ocupada pelo arquivo, em pleno centro da cidade pode ser aproveitada de melhor forma.

É significativo observar a contradição nas palavras do secretário, que ao mesmo tempo que afirma tratar-se de "arquivo morto", fala da necessidade de nele localizar processos solicitados pela Justiça. Se a administração necessita destes documentos para provar suas ações, se estes documentos têm valor administrativo e legal para mesma, estaria morto o arquivo?

\footnotetext{
${ }^{40}$ Com o título, "Arquivo Central de São Bernardo conta com novas instalações”, o Diário Regional de 07 de agosto de 2003, noticia a inauguração no dia $1^{\circ}$ de agosto das novas instalações do Arquivo Central e Serviço de Microfilmagem.
} 
O conceito da documentação pública expresso por um de seus gestores e as conseqüências decorrentes deste, que encontramos permeando a administração pública, foi sintetizada por Billota (et al., 1984),

\begin{abstract}
"Os documentos públicos, sem sofrer avaliação nem tratamento adequado, tendem, portanto, a ser percebidos pelos administradores não como uma fonte de informações, mas como uma carga pesada e poeirenta da qual é necessário livrar espaços preciosos para ocupações "mais nobres". Perde-se, assim, muitas vezes, a perspectiva de seu valor como elemento integrante do patrimônio público e cultural, e se tomam decisões acerca de seu destino de forma arbitrária, lesando na prática a comunidade, e, particularmente, a pesquisa históricosociológica".
\end{abstract}

Assim é que o Arquivo Central de Santo André, para dar lugar a um restaurante para funcionários, passou do Térreo II do Paço Municipal para um galpão sobre o Sacolão de Utinga da Craisa-Companhia Regional de Abastecimento Integrado, em 1991. E o Serviço de Arquivo de Diadema, saiu do Paço Municipal para duas áreas, rua do Tanque e a rua Graciosa, em 1993 e em 2001, deixou uma área central na rua Graciosa que foi ocupada pela Guarda Municipal, sendo transferido para as alas do fundo de um antigo Hospital Psiquiátrico, às margens da Represa Billings, desapropriado em 1995 pela prefeitura da cidade. O Arquivo Geral de Santo André, junto a um sacolão tem seu acervo ameaçado por umidade, infestação, ausência de segurança, enquanto que o Serviço de Arquivo de Diadema fica junto à represa Billings, e além da inadequação das instalações fica em uma área de mananciais, com altos índices de umidade contribuindo para a deterioração da documentação pública. 
Em Ribeirão Pires, o Arquivo de Processos ocupa parte da Garagem Municipal, e o de documentos avulsos de várias secretarias, um depósito conhecido como "Galpão da Merenda".

Já os Serviços de Protocolo, como têm contato direto com a população e, portanto, visibilidade, merecem outra localização e cuidados quanto ao mobiliário e equipamentos, funcionando no Paço Municipal ou próximo dele. Mesmo quando o Serviço de Arquivo ainda se localiza no Paço, suas instalações diferem do Serviço de Protocolo. Em Mauá, por exemplo, pudemos ver o Protocolo no andar térreo, em local iluminado, arejado, bem cuidado. E o Arquivo no subsolo, as salas lotadas pelos processos amontoados. A diferença de instalações entre Protocolo e Arquivo aparece também nos demais municípios.

Quanto à posição ocupada por esses órgãos dentro da estrutura organizativa da administração, sua distância dos primeiros escalões demonstra a menor importância dada aos serviços encarregados de custodiar seu patrimônio documental. Em Mauá, dentro da estrutura da Secretaria Municipal de Administração e Modernização Administrativa ${ }^{41}$, a Seção de Protocolo e Arquivo Municipal, pertence a Divisão de Atendimento ao Cidadão (tem o mesmo status de seção, a Zeladoria e Limpeza, a Telefonia, a Correspondência Municipal). Como já observamos, com exceção de São Bernardo do Campo, onde o Serviço de Arquivo está subordinado Secretaria de Governo, nos outros municípios está vinculado à Secretaria da Administração, que também se encarrega do Pessoal, Licitação de Materiais, do Patrimônio Mobiliário e Imobiliário, da Zeladoria, e em alguns casos ainda de serviços como Cemitério, Telefonia e Gráfica. Com um universo a atender e considerando a concepção que possuem dos arquivos, os gestores tendem a relegá-los na ordem de suas prioridades, daí a situação encontrada.

\footnotetext{
${ }^{41}$ Decreto 6.479, de 29/09/2003, altera Decreto Municipal 6.430, de 20 de maio de 2003, no que diz repeito à estrutura organizacional da Secretaria Municipal de Administração e Modernização Administrativa.
} 
Todos os municípios do $A B C$ têm em seu quadro de pessoal o cargo de bibliotecário, algumas prefeituras têm também cargos de museólogo, historiador, sociólogo, mas não encontramos em nenhuma delas o cargo de arquivista. Chamou-nos a atenção entretanto, o cargo de Analista de Documentação e Arquivo, previsto pela Lei $n^{\circ} 4.517 / 01$, do município de Ribeirão Pires. No Anexo IX, que trata das "Atribuições dos Cargos" encontramos para o mesmo:

- Organizar e dirigir bibliotecas, executar serviços de classificação e catalogação de material bibliográfico e documentos.

- Utilizar recursos de processamento de dados nos sistemas de bibliotecas, centros de documentação e serviços de informação.

- Orientar usuários na escolha de livros, periódicos e demais documentos.

- Supervisionar o serviço de conservação de livros e documentação.

- Realizar atividades de identificação de espécies documentais.

- Atuar no planejamento de novos documentos e multicópias.

- Efetuar o planejamento e organização de centros de documentação; dirigir centros de documentação constituídos de acervos arquivísticos e mistos.

- Realizar o planejamento e a organização dos serviços de microfilmagem.

-Promover medidas necessárias à preservação e conservação dos documentos arquivísticos.

- Desenvolver atividades técnicas relacionadas a projetos de sistemas de informações e/ou atividades de análise e capacidade de máquinas.

- Executar tarefas a partir das necessidades de aquisição, implantação, reformulação, instalação e recursos de computação.

O que se pode observar nesse rol de atribuições é o desconhecimento das especificidades que envolvem as atribuições dos arquivos, bibliotecas e centros de documentação, bem como das funções do 
arquivista, bibliotecário e documentalista. Junto a atividades próprias do bibliotecário aparecem alguns ítens previstos nas atribuições dos arquivistas, artigo 12, do Decreto $n^{\circ} 82.590$, de 06 de novembro de $1978^{42}$.

Um outro indicador do status dos Serviços de Arquivo é a escolaridade exigida para o exercício do trabalho e chefia dos mesmos. Assim, não há em geral, exigência de nível superior ou mesmo $2^{\circ}$ grau para as chefias. A Lei $n^{\circ}$ 6.608/90 de Santo André, que trata da reorganização administrativa e de cargos e salários neste município é um bom exemplo: esta lei, estabelece para encarregados de arquivo, a $4^{\mathrm{a}}$ série de $1^{\circ} \mathrm{grau}$ e para encarregado de protocolo, o nível de $2^{\circ}$ grau. Ocorre também que estes cargos são na maior parte dos casos de livre provimento, preenchidos pelos chamados "cargos em comissão".

Dadas as condições de trabalho, em locais inadequados, insalubres muitas vezes, sem equipamentos e materiais necessários, carecendo de visibilidade e valorização por parte da própria Secretaria a que pertencem e de outros setores da administração municipal, muitos desses Serviços trabalham com pessoal reduzido, vários funcionários em "desvio de função", isto é, contratados como trabalhadores operacionais, para serviços de limpeza, por exemplo, que passaram a tratar da documentação pública.

Ao contrário do que ocorreu em outros municípios próximos, como São Paulo, Mogi das Cruzes, Santos - e muitos outros no interior de São Paulo - não houve nas cidades do Grande ABC paulista a instituição de um Arquivo Histórico, apesar de encontrarmos referências a demandas por sua criação.

Em 1981, o memorialista Roberto Bottacin, de Ribeirão Pires, encaminhou ao Prefeito de Santo André, Newton Grillo, um ofício ${ }^{43}$,

\footnotetext{
${ }^{42}$ Regulamenta a Lei $\mathrm{n}^{\circ}$ 6.546, de 04 de julho de 1978, que dispõe sobre a regulamentação das profissões de Arquivista e de Técnico de Arquivo.

${ }^{43}$ Processo 32.422/81, fls. 3 e 4, Prefeitura Municipal de Santo André, cópias constantes do Dossiê "Museu da Cidade de Santo André", organizado por Wilson Roberto Stanziani, primeiro diretor do Museu.
} 
solicitando a instalação de um Museu, Instituto Histórico e Geográfico e Centro de Documentação Histórica:

“(...) um Centro de Documentação seria de grande interesse cultural, além de uma inegável fonte de informações a qual seria de grande utilidade para estudantes, historiadores, professores, órgãos da imprensa e população conseguir cópias de documentos e fotografias, documentos de nossos municípios desde a fundação.

O Centro de Documentação ou Arquivo Municipal poderia conter não documentos referentes a Santo André, mas também de todas as cidades da região, São Bernardo, São Caetano do Sul, Mauá, Ribeirão Pires, Rio Grande da Serra, Suzano, Mogi, Baixada Santista, Grande São Paulo, Capital e Bairros de São Paulo."

O signatário afirma ainda que não seria difícil a arrecadação de documentos, pois só com a sua coleção e a de Otaviano Gaiarsa ${ }^{44}$ teriam mais de quatro mil documentos e fotografias, entre 1860 e 1950.

O que se percebe aqui é o desconhecimento das diferenças entre Centro de Documentação e Arquivo Municipal tratados indistintamente, e por outro lado, já o interesse recorrente no estabelecimento de uma instituição reunindo documentação e informações sobre a região, no caso deste memorialista bastante alargada, ainda que entendamos as relações da história do Grande ABC, com São Paulo, Santos, Mogi das Cruzes, etc.

Por ocasião dos Congressos de História do Grande $A B C$, que ocorrem a cada dois anos na região, surgiram manifestações para a constituição de Arquivos Históricos Regionais: durante o V Congresso em Mauá (Jornal Diário do Grande ABC, 05 de setembro de 1998, Caderno Diário Educação, p.1. "Patrimônio histórico terá arquivo regional") e também no VIII Congresso em Paranapiacaba, durante a mesa "Memória Social e

\footnotetext{
${ }^{44}$ Memorialista de Santo André, autor de "A cidade que dormiu três séculos".
} 
História Regional: é importante sabermos nossa história?" no dia 23 de julho de 2004. Nesta ocasião o prof. dr. William Puntschart reivindicou a constituição de um arquivo público regional e o prof. dr. José Amilton de Souza endossando a proposta defendeu que este podia ser criado junto a Universidade Pública do $\mathrm{ABC}$ a ser implantada na região.

Também encontramos na imprensa manifestações a respeito da implantação de Arquivos Históricos. Na Coluna Memória, Diário do Grande $A B C$, do dia 18 de abril de 2004, em matéria intitulada "Família Mauaense", o jornalista e memorialista Ademir Medici, fala da guarda e disponibilização pelo Núcleo de História e Memória de Mauá, da Secretaria da Educação, Cultura e Esportes local, das fichas funcionais dos trabalhadores da Porcelana Mauá (antes estavam sob custódia do Sindicato dos Ceramistas). Com a chamada "A meta: o arquivo histórico municipal", segundo a coluna "A meta do Núcleo é chegar ao Arquivo Histórico Municipal, relata o historiador Willer Bonni, seu coordenador, sempre com a preocupação de recuperar, preservar, difundir e refletir sobre a historiografia da cidade." O jornalista conclui a matéria afirmando, "E o Grande $A B C$, finalmente, sete Congressos de História depois, às vésperas de realizar o VIII Congresso, ganhará o seu primeiro arquivo histórico dentro da perspectiva sonhada e mostrada pelo acadêmico Antonio José Marques."

Manifesta-se ainda hoje uma visão culturalista de arquivo. Conforme Jardim (1995), "No Brasil privilegia-se a dicotomia valor histórico/valor administrativo dos acervos arquivísticos. Como tal, a monumentalização dos documentos e a negligência de seus aspectos informacionais têm norteado, com exceções produzidas a partir dos anos 80 , a maioria das nossas instituições arquivísticas públicas. Suas relações com o conjunto da administração pública são pouco freqüentes."

Para a maior parte dos gestores e funcionários da administração pública, sejam ligados à Administração, sejam ligados ao Departamento da Cultura, e para outros segmentos da população, ainda vigoram conceitos de 
"documento histórico", envoltos em uma aura de "antiguidade" e "importância".

A qualificação "histórico" dada ao documento, esclarece Bellotto (2004) teve ao longo da vida brasileira, uma conotação positivista, ufanista e grandiloqüente.

Daí não haver estranhamento por parte das administrações de encaminhar, e, muitas vezes, por parte das instituições de receber documentos públicos de arquivo enviados para museus, bibliotecas, centros de memória e documentação, dado o desconhecimento da especificidade do documento público de arquivo e dos princípios e metodologias arquivísticos (manter a integridade dos fundos, o respeito a proveniência, o princípio da organicidade, a necessidade de um plano de classificação e de um processo de avaliação dos documentos produzidos, entre outros). Aqui é importante ressalvar a preocupação do Museu de Santo André, que tendo a custódia do Fundo Câmara e Intendência de São Bernardo do Campo (1890 - 1937) contratou uma especialista em organização de arquivos para fazer o arranjo desta documentação conforme os preceitos da arquivística. Também percebemos as mudanças ocorridas nestas instituições quanto a maneira de pensar, organizar e disponibilizar seus acervos e maior clareza quanto às características e correta destinação dos documentos públicos. A qualificação dos profissionais e as atividades da Comissão Técnica das Instituições Oficiais de Memória da Região do ABC têm contribuído para isto. ${ }^{45}$

A naturalidade, uma das características do documento de arquivo, é elucidativa desta questão, como aponta Camargo (2003),

\footnotetext{
${ }^{45}$ Com relação a especificidade dos documentos públicos de arquivo e a necessidade da instituição de um Sistema de Arquivos e um Arquivo Público Municipal nos municípios do Grande ABC, esta comissão encaminhou em 2002 a todas as administrações municipais da região, o documento "Em defesa de um Sistema Municipal de Arquivos". As prefeituras de Rio Grande da Serra, Ribeirão Pires e Diadema não deram qualquer resposta. As prefeituras de Mauá, Ribeirão Pires, Santo André, São Bernardo e São Caetano acusaram seu recebimento, mas não houve qualquer ação no sentido proposto. O documento citado é dos anexos desta dissertação.
} 
“(...) o documento de arquivo tem como traço característico o fato de ser produzido de forma natural e rotineira, por imperativos de ordem prática, sem qualquer intenção de se transformar em fonte para a história. No âmbito do funcionamento de uma instituição, com efeito, não resulta de um gesto especial de atribuição de sentido, como ocorre com os documentos de museu; ao contrário, tem caráter evidencial congênito, isto é, nasce para servir de instrumento ou prova de determinadas ações e é alheio a um eventual uso secundário que dele se possa fazer."

Ainda sobre a preocupação em se custodiar "documentos históricos" lembramos como Bellotto (2004), que "a história não se faz com documentos que nasceram para ser históricos, nem com autógrafos de grandes figuras, nem com documentos isolados que signifiquem o ponto final de algum ato administrativo e sim, ademais de outras fontes, com a "papelada" gerada pelo cotidiano da vida administrativa".

Esgotado seu uso administrativo, podem ou não, os conjuntos documentais produzidos pela administração pública passar a constituir seu "arquivo permanente", após a execução criteriosa dos procedimentos de avaliação, respeitados os princípios arquivísticos, da proveniência ${ }^{46}$ e da organicidade $^{47}$. Teremos então os fundos de arquivo ${ }^{48}$ produzidos pelos vários órgãos da administração, refletindo a mesma e suas ações, e não "preciosidades, colecionadas aqui e ali, recolhidas para que, com elas, o historiador estabeleça suas fontes" (BELLOTTO, 2004).

Cabe ao historiador, conforme Camargo (2003), através do esforço de ultrapassagem, nos processos de interpretação e produção de sentido, tornálos históricos.

\footnotetext{
${ }^{46}$ Fixa a identidade do documentos relativamente a seu produtor. (...) os arquivos devem ser organizados em obediência à competência e às atividades da instituição ou pessoa legitimamente responsável pela produção, acumulação ou guarda dos documentos (Bellotto, 2002).

${ }^{47}$ Organicidade (em seu relacionamento com outros documentos do conjunto): interdependência entre os documentos do mesmo conjunto e suas relações com seu contexto de produção (Bellotto, 2003).

${ }^{48}$ Unidade constituída pelo conjunto de documentos acumulados por uma entidade, que no arquivo permanente passa a conviver com arquivos de outras (Camargo e Bellotto, 1996).
} 
Ao tratar dos arquivos das administrações municipais do $A B C$, utilizamos como epígrafe o Minotauro e seu Labirinto, buscando relacionar a fragmentação em que se encontram esses documentos públicos, dispersos em diferentes órgãos das administrações, depositados muitas vezes sem organização e qualquer tipo de instrumento de pesquisa que facilite sua busca, deixando desorientados aqueles que deles necessitam, como se estivessem errando pelas salas e passagens intrincadas do palácio construído por Dédalo em Creta, onde vivia o Minotauro. Para as administrações, a massa documental acumulada passa a ser tão terrível como o Minotauro que tentaram aplacar com as iniciativas pragmáticas que veremos no próximo capítulo. 


\title{
4. - Iniciativas de gestão documental nos arquivos públicos do ABC - A tarefa de Sísifo
}

\author{
" ...Sísifo, cuja tarefa consistia em rolar uma \\ enorme pedra até o alto de um morro, mas quando já se \\ encontrava bem avançado na encosta, a pedra, \\ impelida por uma força repentina, rolava de novo para a \\ planície."
}

Thomas Bulfinch - O Livro de Ouro da Mitologia

\section{1 - Arquivo público - identificação e coordenadas} contemporâneas

Ainda que a função de arquivar remonte a antiguidade ${ }^{49}$, a atual concepção de arquivo público está ligada a história dos Estados modernos.

Nos séculos XVI e XVII, aparecem as primeiras idéias de centralização de arquivos na Península Ibérica, mas sua institucionalização só adquiriu forma na França ao final do século XVIII, durante a Revolução Francesa. Uma seqüência de ações é de significativa importância para a constituição dos arquivos públicos:

- A criação, em 1789, pela Assembléia Nacional, de um arquivo no qual deveriam ser guardados e exibidos os seus atos. Um ano depois, por

\footnotetext{
${ }^{49}$ Para Gagnon-Arguin (1998), "O nascimento dos arquivos e da arquivística remontaria ao aparecimento da escrita". E afirma Herrenschmidt (apud Desalle, 1998), "Tudo teria começado por volta de 3.300 a.C. no sul do Iraque e sudoeste do Irã, quando os funcionários inventaram um meio de arquivar o pagamento dos impostos, representando na argila a quantidade de produtos registrados e sua natureza. Assim nasceram o primeiros sinais gráficos, os algarismos para as quantidades e os desenhos para as coisas". Traduzimos.
} 
decreto de 12 de setembro de 1790, esse arquivo passou a constituir os Archives Nationales.

- A determinação de que os Archives Nacionales passariam a ter jurisdição sobre os depósitos de documentos de todos os órgãos do governo central e dos governos provinciais em 1794, jurisdição essa ampliada pouco depois para os arquivos distritais.

- O estabelecimento do acesso dos cidadãos comuns aos arquivos, pela Lei de 7 Messidor.

- A conservação dos documentos do Antigo Regime, considerando que os documentos do Trésor de Chartes e da Curia Régis eram de propriedade pública e que portanto deviam ser preservados e que o povo devia ter acesso aos mesmos.

A importância destas medidas ligadas a Revolução Francesa é assinalada por Schellenberg (2002) como o reconhecimento da importância dos documentos para a sociedade, e teriam "resultado em três importantes realizações no campo arquivístico:

1. Criação de uma administração nacional e independente dos arquivos.

2. Proclamação do princípio de acesso do público aos arquivos.

3. Reconhecimento da responsabilidade do Estado pela conservação dos documentos de valor, do passado.

Como ocorreu na França, outras nações da Europa e depois da América constituíram seus arquivos públicos, sendo que as circunstâncias de seu estabelecimento, e, já no século XIX, o historicismo e o romantismo associados às tendências da historiografia da época, fizeram com que prevalecesse nestes arquivos o viés histórico mais que o administrativo. Esta concepção historicista perduraria até o início do século $\mathrm{XX}$.

No período entre as guerras mundiais e particularmente após a II Grande Guerra, este modelo se transformou devido a complexidade crescente das administrações e ao desenvolvimento das técnicas 
reprográficas, responsáveis pela produção de grandes massas documentais. Discorrendo sobre o crescimento do volume dos documentos oficiais, Schellenberg (2002) o relaciona com o aumento da população verificado desde meados do século XVIII, que por sua vez provocou a expansão das atividades dos governos e o maior volume de documentos, ampliado pela aplicação das modernas tecnologias na produção dos mesmos. O controle dos documentos, a questão da custódia e da eliminação dos mesmos, passam a ser preocupações ligadas às administrações e aos arquivos. Assim, a avaliação dos documentos foi objeto de diferentes abordagens na Inglaterra, na Alemanha, na União Soviética. Nos Estados Unidos e no Canadá criaram-se comissões governamentais visando racionalizar a produção e o tratamento documental. Como resultado temos o aparecimento do conceito de gestão de documentos, "conjunto de procedimentos e operações técnicas referentes às atividades de produção, uso, avaliação e arquivamento de documentos em fase corrente e intermediária, visando a sua eliminação ou recolhimento para guarda permanente" (INDOLFO, apud RONDINELLI, 2002).

Decorrente ainda desta preocupação, é enunciada também nos Estados Unidos, a teoria das três idades, que segundo Bellotto (2002), pode ser considerada "o ponto de chegada natural dos estudos arquivísticos, que desde o século XIX, tentavam estabelecer uma ponte entre a documentação de gestão e a destinada a ser preservada para fins de pesquisa." Parte do princípio que, seja parte integrante do arquivo de uma pessoa ou de uma instituição, qualquer documento de arquivo passa por um ou mais períodos caracterizados pela freqüência e tipo de utilização que dele é feita. Também conhecida como "ciclo vital dos documentos" estabelece que os documentos produzidos pela administração correspondem a uma primeira idade, os documentos correntes, ativos ou de gestão, freqüentemente consultados; os documentos da segunda idade, já na fase semi-ativa, são utilizados mais por razões jurídicas que administrativas. Constituem os chamados arquivos 
intermediários onde os documentos aguardam os prazos indicados pelas tabelas de temporalidade antes de sua destinação: eliminação ou guarda permanente. Finalmente, os documentos de terceira idade ou de guarda permanente, servem aos cidadãos e aos pesquisadores, graças a seu valor informativo e para a história e memória.

A aceitação deste princípio decorre para Couture (1998), do fato de,

\begin{abstract}
"permitir uma repartição essencial dos grandes conjuntos que formam o arquivo de uma pessoa física ou moral (...) O conceito de ciclo de vida transforma um conjunto de documentos quantitativamente demasiado importante, desmedido em relação aos meios de que se dispõe para se Ihe fazer face, em subconjuntos que apresentam diferentes características."
\end{abstract}

Ainda nos Estados Unidos, para agilizar o sistema de controle arquivístico, foi instituído o arquivamento intermediário. ${ }^{50}$

Também chamado de depósito de pré-arquivamento ("depôt de préarchivage" para os franceses, "records centers" para os Estados Unidos), permite o armazenamento dos documentos que deixaram a fase corrente em lugares menos dispendiosos, aguardando o tempo necessário para que as medidas previstas nos documentos de "destinação" (tabelas de temporalidade, planos de destinação) possam ser aplicadas, eliminando ou transferindo para os arquivos permanentes os documentos após o cumprimento dos prazos previstos.

\footnotetext{
50 "Em decorrência do grande volume de documentos produzidos durante a Segunda Guerra Mundial pela Marinha e Exército, instalou-se o primeiro depósito intermediário. A economia proporcionada por esses depósitos foi tão evidente que o Arquivo Nacional, em Washington, resolveu adotar institucionalmente a fórmula do arquivamento da segunda idade. Em 1950, com a promulgação do Federal Records Act, proposto pela segunda Comissão Hoover, estabeleceu-se a divisão dos EE.UU. em 10 regiões administrativas, devendo cada uma delas possuir um arquivo intermediário de âmbito federal. (...) Em 1954, 10 arquivos intermediários já estavam definitivamente implantados (Franco, 1984).
} 
As Grandes Guerras Mundiais trouxeram ainda o desenvolvimento e a disseminação dos meios de micro-reprodução, entre eles a microfilmagem. Esta tecnologia que "foi grandemente utilizada no pós-guerra para duplicação de arquivos que haviam sido transferidos por motivos políticos e cuja restituição não fora efetuada" (SILVA, 1999), também será utilizada em grande escala como solução para o acúmulo das grande massas documentais geradas pelas administrações públicas.

Traçamos aqui um breve histórico do aparecimento da instituição "arquivo público", passando por seu caráter inicial ligado a história para chegar ao conceito atual, em que uma política de gestão documental permite a integração entre suas várias fases ou idades e o fluxo documental entre elas, garantindo que o arquivo cumpra sua dupla função, para a administração e para a pesquisa, seja histórica, seja de outros campos do conhecimento, facultando a todo e qualquer cidadão o acesso ao documento público.

A partir destas considerações analisaremos as iniciativas de gestão documental que observamos nos municípios do Grande ABC.

\section{2 - Duas experiências pragmáticas de gestão documental no}

\section{Grande ABC}

Algumas iniciativas isoladas serão apenas mencionadas, quando algum setor ou órgão da administração municipal preocupado com a documentação que produz ou acumula, tomou a iniciativa de seu tratamento. Isto ocorreu, por exemplo, em Santo André, quando o Departamento de Comunicação contratou os serviços de uma especialista em arquivos para o tratamento de seu acervo fotográfico, em 1990. Ou em Ribeirão Pires, quando a Gerência de Suprimentos da Secretaria de Administração contratou em 2003, a empresa “D’Archives - Gestão Documental e Informática Ltda.", para organizar os documentos de seu interesse. Como 
iniciativas localizadas e pontuais, não tiveram relevância para o tratamento da documentação produzida pelo conjunto da administração.

Como apontamos anteriormente, inexistindo um Sistema Municipal de Arquivos e um Arquivo Público Municipal, a responsabilidade pelos documentos de acordo com a legislação dos municípios estudados é atribuída à Secretaria da Administração ou do Governo. E é das iniciativas destes órgãos que trataremos, já que nos municípios de Santo André, São Bernardo do Campo, São Caetano do Sul e Diadema tivemos o estabelecimento, por período de tempo variável, de práticas de microfilmagem e de avaliação dos documentos.

\subsection{1 - Avaliação documental}

Foi durante os anos 70 que os municípios de Santo André, São Bernardo do Campo e Diadema empreenderam as primeiras tentativas pragmáticas de avaliação documental. Em Diadema, a Portaria $n^{\circ}$ 08/72, aprovava um Manual de Arquivo da Prefeitura Municipal visando à elaboração de arquivo e controle de documentos em geral. Previa as competências dos arquivos e uma comissão de avaliação e controle de documentos (CACD). Já o Decreto $n^{\circ}$ 4.373, de 16 de julho de 1975, dispunha sobre a constituição do Grupo Inter Setorial de Liberação de Papéis e Documentos - GILPA, em São Bernardo do Campo. E em Santo André, o Decreto $n^{\circ} 8.943$ de 14 de janeiro de 1977, tratava da constituição do Grupo Inter Setorial de Liberação de Papéis e Documentos - GISELPA.

Quanto ao município de São Caetano, apesar de constatarmos através do relato de funcionários o funcionamento de comissões de avaliação de documentos e de termos localizado o número do processo que trata do assunto $^{51}$ e da autorização do Diretor do Departamento de Administração

\footnotetext{
${ }^{51}$ Processo Interno $n^{\mathrm{o}} 379 / 92$.
} 
para consultá-lo, não tivemos acesso ao mesmo, apesar de inúmeras tentativas, pois, segundo informações do Departamento Jurídico para onde foi encaminhado, não conseguiram localizá-lo.

\subsubsection{1 - Santo André}

O primeiro documento relativo ao tema, é o Decreto $n^{\circ} 8.943$, de 14 de janeiro de 1977, que constituía o Grupo Inter-Secretarial de Liberação de Papéis e Documentos - GISELPA, composto por representantes das Secretarias da Prefeitura Municipal de Santo André, sob a presidência do Chefe da Divisão do Expediente Geral da Prefeitura Municipal de Santo André, com competência para estudar e propor ao Secretário dos Assuntos Internos e Jurídicos a incineração de papéis e expedientes arquivados ou depositados nas repartições municipais (artigo $1^{\circ}$ ). Estes representantes seriam indicados pelas Secretarias e a comissão, instalada pela Divisão de Expediente Geral, poderia "solicitar às secretarias relatórios sobre os expedientes a serem incinerados." Instituído no último ano desta gestão, não chegou a funcionar efetivamente.

Já na gestão seguinte, em 08 de junho de 1978, o Decreto $n^{\circ} 9331$, revogou o de $n^{\circ} 8.943$, estabelecendo algumas alterações: ficou responsável pela instalação e direção do Grupo InterSecretarial de Liberação de Papéis e Documentos - GISELPA, a Secretaria de Assuntos Internos e Jurídicos (artigo $1^{\circ}, \S 2^{\circ}$ ), determinou-se que, "anualmente na primeira quinzena de janeiro, o GISELPA procederá ao levantamento de papéis e expedientes que possam ser inutilizados, determinando, em seguida, a execução do trabalho de inutilização." Como inovação em comparação com o decreto anterior, foi incluído o artigo $6^{\circ}$ sobre documentos de valor histórico: "Os documentos julgados como de valor histórico deverão ser remetidos à Secretaria de Educação e Cultura". Com relação ao destino destes documentos é 
interessante lembrar que nesta época não existiam em Santo André, Arquivos ou Museus Históricos, apenas a Biblioteca Pública Municipal. ${ }^{52}$

Acreditamos que esta alusão seja resultado dos estudos que se faziam para a introdução do sistema de microfilmagem de documentos que começou nesta gestão em 1979, já que a Lei Federal $n^{\circ} 5.433$, de oito de maio de 1968, que regula a microfilmagem de documentos oficiais ${ }^{53}$, em seu artigo $2^{\circ}$ estabelece, "Os documentos de valor histórico não deverão ser eliminados, podendo ser arquivados em local diverso da repartição detentora dos mesmos."

Só em 1991, um novo decreto tratou da questão de avaliação de documentos, o de $\mathrm{n}^{\circ} 12.660$, de 28 de janeiro de 1991, ainda se remetendo ao GISELPA, mas trazendo várias inovações e mudanças.

Este decreto deve ser analisado no contexto da $1^{\text {a }}$ administração Celso Daniel (1989-1992). No período que antecedeu seu mandato, durante os anos 80 , ocorreram no Grande $A B C$ vários eventos, alguns já citados no primeiro capítulo deste trabalho, ligados a uma preocupação acentuada com a História e Memória da região. Por exemplo, o Diário do Grande ABC, de 31 de agosto de 1988, anunciava, "Pesquisadores da Memória sugerem medidas a candidatos: Documento é resultado de debates realizados nos dias, 16, 23 e 30/8 no CEPS" 54 Segundo a matéria, "o coordenador Paschoalino Assumpção sugere que o grupo passe a se chamar Grupo Independente de Pesquisadores da Memória do ABC - GIPEM o que foi aprovado. Também foi aprovado um documento com cinco sugestões para os candidatos, entre elas:

- a criação do Conselho de Defesa do Patrimônio Histórico, Arquitetônico, Cultural e Ambiental e Plano de Ação Integrada de Proteção do Patrimônio Cultural;

\footnotetext{
${ }^{52}$ A Biblioteca Pública Municipal de Santo André (hoje Biblioteca Nair Lacerda) foi criada pela Lei $\mathrm{n}^{\mathrm{o}} 732 / 52$ e instalada em 1954, enquanto que o Museu de Santo André foi criado pela Lei 5.942/82.

${ }^{53}$ A Lei Federal $n^{\circ} 5.433 / 68$, foi regulamentada pela Portaria MJ no 58, de 20/06/1996 e pelo Decreto $n^{\circ} 1799$, de 30/01/1996.

54 CEPS - Centro de Estudos Políticos e Sociais do ABC com sede em Santo André.
} 
- estímulo a pesquisa da documentação com a criação, implantação e aperfeiçoamento do Museu e Arquivo Histórico Municipais, para registro e estudo da documentação oficial e da documentação gerada nos vários segmentos da comunidade: sindicatos, SABs, clubes de serviço, etc." ${ }^{55}$

O ano de 1989, primeiro deste governo, foi marcado por vários Ciclos de Palestras alusivos ao centenário da emancipação da região do $A B C$ de São Paulo, com a criação da Vila de São Bernardo. Em 1990, após o restauro do prédio do $1^{\circ}$ Grupo Escolar, nele foi instalado o Museu de Santo André, ocorrendo simultaneamente o $1^{\circ}$ Congresso de História do Grande $A B C$, e logo depois foi sancionada a Lei Municipal $n^{\circ} 6.673$, de 17 de agosto de 1990, que dispunha sobre a defesa do Patrimônio Histórico, Artístico, Arquitetônico, Urbanístico e Paisagístico de Santo André, criando seu respectivo Conselho ${ }^{56}$.

Portanto, o Decreto no 12.660, de 28 de janeiro de 1991, que "dispõe sobre o Arquivo Interno da Prefeitura Municipal de Santo André e dá outras providências", incorpora estas duas novas instituições.

Já no seu preâmbulo, este decreto se refere a "Lei da Microfilmagem":

"O Prefeito Municipal de Santo André no uso de suas atribuições legais, e em conformidade com a Lei Federal $n^{\circ} 5.433$, de 08 de maio de 1968", DECRETA:" (...)

Assim como nos decretos anteriores o objetivo declarado no artigo $1^{\circ}$ é "a inutilização de papéis e expedientes arquivados ou depositados nas repartições municipais." Esta comissão intersecretarial, GISELPA, se reuniria semestralmente, nos meses de março e setembro e seu objetivo seria verificar o cumprimento das determinações do decreto, examinando as rotinas de liberação dos documentos, os livros de registros das ações de microfilmagem, transferência e eliminação de documentos previstos, e ainda poderia propor o aprimoramento das ações.

\footnotetext{
${ }^{55}$ A referência feita é aos candidatos a prefeito dos municípios do $\mathrm{ABC}$, dadas as eleições municipais neste ano.

${ }^{56}$ COMDEPHAAPASA - Conselho Municipal de Defesa do Patrimônio Histórico, Artístico, ArquitetônicoUrbanístico e Paisagísitico de Santo André.
} 
Era constituída junto ao GISELPA, a Comissão de Arquivo Histórico (artigo $3^{\circ}$ ), composta por um representante do Museu Municipal e um representante do Conselho Municipal de Defesa do Patrimônio Histórico, Artístico, Arquitetônico e Paisagístico de Santo André, cuja função seria definida mais adiante: o Arquivo Intermediário enviaria periódicamente a esta Comissão, documentos cujo prazo para guarda tivesse expirado para "exame documental". E esta, devolveria ao Arquivo Intermediário os documentos que deveriam ser eliminados (artigo $6^{\circ}$ e parágrafo único do mesmo artigo).

Observamos que apenas aqui aparece a expressão Arquivo Histórico (que aliás não foi constituído por qualquer estatuto legal nesta administração nem nas seguintes), pois o artigo $5^{\circ}$ classifica "os arquivos internos para efeitos de organização interna, em: correntes, intermediários e permanentes. Os documentos dos arquivos correntes, documentos em curso ou consultados frequentemente, seriam conservados ora nas repartições que os produzem, ora em dependências de fácil acesso. Os arquivos intermediários, documentos que perderam sua atualidade, mas poderiam ser solicitados, seriam conservados no arquivo geral da prefeitura. Finalmente, quanto ao arquivo permanente, documentos que não teriam mais valor administrativo e que por seu valor histórico ou documentário seriam conservados no Museu Municipal".

De forma genérica eram identificados e estabelecidos prazos para a guarda e eliminação de alguns documentos, por exemplo, "os documentos relativos ao crédito tributário deverão ser conservados até a prescrição dos respectivos créditos" ou "os créditos relativos a administração de pessoal deverão ser conservados durante o prazo de 40 anos".

Este decreto determinava também a criação de Tabelas de Temporalidade em todas as unidades da Prefeitura Municipal, que identificariam a vida útil dos documentos gerados bem como seus prazos de guarda ou eliminação, ficando cada unidade com a responsabilidade de definir "individual e anualmente" sua tabela. 
No que diz respeito a eliminação dos documentos, o artigo $8^{\circ}$ faz referência ao Anexo II, que trata de documentos a serem microfilmados e eliminados, o artigo $10^{\circ}$ trata do Anexo III, documentos a serem eliminados sumariamente, sem microfilmagem. $\mathrm{E}$ o artigo $11^{\circ}$, determina que a responsabilidade pela eliminação é do Prefeito Municipal e dos respectivos secretários podendo ser delegada mediante portaria aos diretores das diversas unidades.

Quanto aos anexos, o primeiro deles é o de Tabela de Temporalidade que todas as unidades administrativas deveriam preencher, com os campos geralmente constantes deste tipo de instrumento: tipologia documental, prazos de arquivamento, guarda e/ou eliminação, destinação. Relativos a destinação final, figuram os campos: Arquivo Permanente, Microfilmagem, Eliminação. Como vimos no decreto o Arquivo Permanente se confunde com o Museu Municipal. A leitura dos anexos II e III, demonstra que tratam apenas do documento "processo administrativo", a maior parte relativos a uso e ocupação do solo ${ }^{57}$, pessoal e regularização de atividades comerciais. No anexo III, solicitações de serviços públicos, como "remoção de árvore", "mudança de poste", etc., e no último ítem, "reclamações e abaixoassinados".

A análise deste decreto evidencia que a exemplo dos que 0 precederam $^{58}$, seu principal objetivo era a eliminação dos documentos, "liberando papéis e documentos", normatizando os que deviam ser microfilmados antes da destruição. A ênfase era para os processos administrativos e a inclusão do ítem referente ao Arquivo Histórico, tentava responder a demandas da época e ao estabelecido pela legislação sobre microfilmagem, com os equívocos comuns ao determinar que o Arquivo devia ser constituído por documentos escolhidos pelo fato de serem "históricos".

\footnotetext{
${ }^{57}$ Aqui lembramos que ao analisar a situação dos arquivos da cidade de São Paulo em 1990, com relação ao Arquivo Geral, ou Arquivo de Processos, Daíse Apparecida de Oliveira aponta que dos 376.800 processos anuais, 60\% eram relativos ao uso e ocupação do solo urbano. Revista do Arquivo Municipal $\mathrm{n}^{\circ}$ 199, Departamento do Patrimônio Histórico. São Paulo: 1991.

${ }^{58}$ Decretos n $^{\circ} 8943 / 77$ e no 9331.
} 
No dia 25 de abril de 1991, o jornalista e memorialista Ademir Médici, integrante na época do Projeto Viva Cidade da Coordenadoria do Planejamento, enviou correspondência à Coordenadora do Projeto ${ }^{59}$, às várias secretarias municipais, setor de informática e microfilmagem, gabinete do prefeito, Museu de Santo André e representante do CONDEPHAAPASA informando do "alerta que recebeu da Diretora do Arquivo Municipal de São Paulo devido ao disposto no Decreto 12.660/91". Questiona tanto a destruição de processos listados no anexo II, que seriam destruídos após microfilmagem, como a destruição dos processos do anexo III, eliminados sem prévia microfilmagem. Questiona ainda o fato de o decreto determinar que cada unidade administrativa elabore sua Tabela de Temporalidade, comparando com a criação de comissões multidisciplinares de avaliação da prefeitura de São Paulo. Chama a atenção para o fato de não ter sido constituída a Comissão do Arquivo Histórico, de estarem fragmentando processos administrativos (todos dos anos 50, com exceção do ano de 1954) de acordo com as tabelas anexas ao decreto. E ainda, para o fato de estar sendo feita a avaliação e microfilmagem apenas a partir dos processos depositados no Arquivo Geral, sem considerar os que não retornaram, que ficariam portanto, sem avaliação nem microfilmagem. Às indagações que fez em vários setores da prefeitura, a resposta foi que documentos estavam sendo eliminados por falta de espaço. Finalmente chama a atenção da administração para "o compromisso que tem com os setores voltados ao resgate da memória (...) que tem sido fielmente seguido com várias demonstrações práticas (...) que quanto ao sistema de arquivo não poderá alegando problemas de espaço, seguir trilhas de administrações passadas que feriram de morte acervos inteiros - os processos anteriores a 1929 foram simplesmente destruídos anos atrás, sem nenhum registro." Em sua "cruzada" por vários setores da administração conseguiu que a Secretaria de Educação, Cultura e Esportes abrigasse documentos que não deveriam ser

\footnotetext{
${ }^{59}$ Cópia. Pasta Arquivos. Acervo Museu de Santo André.
} 
eliminados, assumindo o compromisso de instalar em Santo André um "sistema moderno de arquivo, seguindo os passos de São Paulo e Rio Claro".

Apesar das promessas, não houve qualquer avanço no sentido de constituir um Sistema de Arquivos e um Arquivo Público Municipal como o proposto. Como mencionado no capítulo anterior o Arquivo Geral realmente foi transferido para um salão em cima das dependências da CRAISA - e documentos e livros da Câmara e Prefeitura Municipal de São Bernardo e processos da Prefeitura Municipal de Santo André (1940-1969) foram levados para o museu da cidade. ${ }^{60}$

Um dos protagonistas dos acontecimentos desta época declarou que a Secretaria da Administração tinha como principal alvo a informatização, considerando esta e a microfilmagem como soluções para a questão documental, não era possível convencê-los da necessidade de estabelecer uma política arquivística de gestão documental, precedendo os processos de informatização e microfilmagem. Por outro lado, a administração também entendia que os documentos caracterizados como "históricos" eram responsabilidade do Museu Municipal. E os gestores deste, sabendo qual é verdadeiramente a função do museu e como este havia sido instalado há pouco tempo, temiam que o mesmo perdesse sua identidade assumindo o papel de Arquivo.

Uma nova administração tomou posse em 1993 e os últimos documentos que localizamos sobre o funcionamento do GISELPA datam de 1994: são convocações para reuniões no dia 28 de abril de 1994.

A transferência da responsável pela presidência do GISELPA para outro setor e a não indicação de um substituto prejudicou a continuidade da tarefa.

\footnotetext{
${ }^{60}$ Quanto aos documentos do Fundo Câmara e Intendência de São Bernardo (1890-1937 o Museu contratou uma especialista em arquivos para dar tratamento arquivístico ao mesmo. E os processos, eram mantidos organizados, higienizados e acondicionados pelos funcionários do Museu, que os disponibilizava quando procurados para consulta.
} 
Com a volta da administração Celso Daniel (1997-2000), durante todo o ano de 1997 a Gerência do Museu de Santo André encaminhou propostas para o tratamento sistêmico da documentação pública, junto ao Departamento de Cultura, ao qual é subordinado, e posteriormente também junto a Secretaria de Administração. Começou por um ofício em que apresentava a situação dos processos administrativos que se encontravam nas dependências do Museu e que por ocasião da pintura do prédio, em 1996, apesar de todas as tratativas feitas pelos funcionários, foram colocados no porão do prédio pelo Coordenador de Atividades sofrendo os efeitos da umidade e poeira do local e perdendo a ordem em que estavam. A Gerente de Preservação de Memória, responsável pelo Museu de Santo André, tinha clareza da necessidade de uma política de arquivos para o município de Santo André e também da instituição do Arquivo Municipal. No documento "Por uma Política de Arquivo Público em Santo André", 61 além destas questões sugere que como a administração "não tem por si só conhecimento técnico para implementar esta Política de Arquivo" seria necessário estabelecer convênios com o Arquivo do Estado, ou contratar técnicos para desenvolver este projeto, respaldados nas tendências arquivísticas modernas.

Além do documento mencionado, foram convidadas duas especialistas em arquivo, para a reunião do dia doze de agosto de 1997, com o responsável da Secretaria da Administração. Apontou-se então, a necessidade de uma Política de Arquivo, da modificação da cultura de guarda dos documentos, de se intervir já nos arquivos correntes em um processo de gestão documental.

Estas propostas não foram encaminhadas, o que ocorreu foi o contato e a cotação de preços com uma empresa, na perspectiva de terceirizar a organização e a guarda desta documentação, o que terminou não se

\footnotetext{
${ }^{61}$ Cópia. Agosto de 1997. Pasta Arquivo, Museu de Santo André.
} 
efetivando ${ }^{62}$. Os processos que estavam no Museu foram encaminhados para o Arquivo Geral e nesse local os problemas continuaram se avolumando.

Não houve continuidade dos trabalhos do GISELPA: no dia 17/08/1998, Márcia Pellegrini, pela Secretaria de Assuntos Jurídicos, historia as ações do grupo e seu resultado e encaminha parecer com suas considerações à Secretaria da Administração, concluindo, "Deste modo, solicito a V.Sa. informe a responsável da possibilidade de incluir esta situação na temática referente a modernização administrativa, para verificar se não existe método mais eficaz de solucionar a questão" ${ }^{63}$

O resultado destas ações, ou poderíamos dizer, não-ações, aparece em um relatório feito em 1999 pela responsável pelo Arquivo. Além de apontar todos os problemas de espaço físico, de pessoal, etc. do Arquivo Geral e a relação de depósito que o restante da administração tem com o mesmo, demonstra as inúmeras falhas na gestão dos documentos, particularmente dos processos (a maior parte dos documentos que guarda e que são procurados e circulam pela administração): das dificuldades do controle dos processos que não retornam e falhas no sistema quanto ao controle da tramitação dos mesmos e a prática já denunciada anteriormente de não se procurar completar a série documental para microfilmagem. Questiona a redação dos decretos que tratam da avaliação dos documentos ("mal redigidos") e a não indicação dos membros para comporem o Gisela, dando continuidade a avaliação.

Ao que pudemos apurar, este estado de coisas não se modificou durante a gestão 2001-2004. Não foram nomeados membros para

\footnotetext{
${ }^{62}$ Quanto a este procedimento é interessante lembrar que existe uma Resolução do Conarq-Conselho nacional de Arquivos, a de $n^{\circ}$ 6/97, que dispõe sobre diretrizes quanto a terceirização de serviços arquivísticos públicos, e estabelece que a avaliação e a guarda dos documentos públicos é exclusiva dos órgãos e entidades do Poder Público, visando garantir o acesso e a democratização da informação, sem ônus, para a administração e para o cidadão (artigos $1^{\circ}$ e $2^{\circ}$ ). Esta resolução estabelece ainda que podem ser contratados serviços para a execução de atividades técnicas auxiliares, desde que planejados, supervisionados e controlados por agentes públicos pertencentes aos órgãos e entidades produtores e acumuladores dos documentos (artigo $3^{\circ}$ ).

${ }^{63}$ Processo Administrativo Interno ${ }^{\circ}$ 8.241/89-6.
} 
constituírem as comissões. O Decreto 12.660/91 não foi revogado ou alterado, apesar da promulgação da Lei 8.159 (Lei de Arquivos), de 08 de janeiro de 1991 e da nova regulamentação da Lei 5433/68 (microfilmagem de documentos), promovida pelo Decreto $\mathrm{n}^{\circ} 1799 / 96$, posteriores ao decreto municipal analisado.

\subsubsection{2 - São Bernardo do Campo}

A avaliação de documentos em São Bernardo tem sua origem ligada a preocupação com o acúmulo de documentos e com a possibilidade de incêndio nas dependências da prefeitura, que determinaram em 1973, a criação de uma Comissão Central de Prevenção Contra o Incêndio no Paço Municipal - CCPCIPM.

O presidente desta comissão, solicitou ao Secretário de Administração medidas para a descentralização do arquivo e sugeriu a implantação do sistema de microfilmagem dos documentos, que teve início no mesmo ano ${ }^{64}$.

No dia 16 de julho de 1975, pelo Decreto 4.373, foi criado o GILPA Grupo Inter-Secretarial de Liberação de Papéis e Documentos. Os motivos para constituição deste grupo são enumerados em seus "considerandos":

- existência de um volume elevado de papéis e expedientes já encerrados os quais se encontram no arquivo e depositados nas respectivas repartições;

- elevado número de papéis constituindo material de fácil combustão, possível foco de incêndio de grande proporções;

- grande parte dos documentos já cumpriram suas finalidades;

- dificuldade de arquivamento, necessidade de conseguir espaço para os novos documentos.

\footnotetext{
${ }^{64}$ Processo Administrativo Interno no $9627 / 73$.
} 
Aos membros desta comissão, constituída por representantes do Grupo Central de Planejamento, da Secretaria de Planejamento e Economia e dos Grupos Setoriais de Planejamento das Secretarias de Assistência Judiciária, Finanças e Governo, competia "estudar e propor a destinação ou incineração de papéis e expedientes arquivísticos que se depositavam nas repartições municipais".

$\mathrm{O}$ artigo $7^{\circ}$ trazia uma ressalva: "Na eventualidade da localização de documentos de valor histórico, o GILPA tomará providências para sua preservação, podendo propor a sua incorporação a museus e entidades congêneres".

Pouco tempo depois, no dia 24 de setembro de 1975, a Portaria nº 6.138, nomeou os membros deste grupo e o relatório apresentado por ele subsidiou a elaboração do Decreto $n^{\circ} 5.589$, de 15 de junho de $1977^{65}$, que dispõe sobre a destruição e incineração de papéis e ainda está em vigor. Este decreto revogava o de $n^{\circ} 4.373$, que constituiu o GILPA, mas utilizando os mesmos considerandos, estabelecia normas para a destruição de documentos, fixando os que não deveriam ser destruídos, como processos protocolados, leis e demais decretos, documentos que representassem títulos de domínio e posse de bens municipais, documentos sujeitos a aprovação do Tribunal de Contas ou da Câmara Municipal, entre outros.

Os outros artigos constituíam uma espécie de tabela relacionando documentos que tinham utilidade estimada em um ano, dois, três e cinco anos. Este decreto, ainda em vigor, não dá conta de toda a documentação produzida pela administração, sobretudo se considerarmos a crescente complexidade da máquina administrativa e as mudanças que ocorreram desde sua promulgação. As disposições genéricas para documentos que não deviam ser destruídos, "que possam interessar a história municipal", ou, "devem ser preservados por outros motivos de interesse público", dão margem a uma vasta gama de interpretações. A dicotomia valor

\footnotetext{
${ }^{65}$ Conforme um dos considerandos do decreto.
} 
histórico/valor administrativo também aparece claramente aqui, ficando a Secretaria da Educação, Cultura e Esportes com a responsabilidade "pelos documentos históricos", como encontramos frequentemente em legislações municipais.

O acúmulo de processos administrativos e a decisão de microfilmá-los, fizeram com que no âmbito das Secretarias da Administração e do Governo novas tratativas fossem realizadas. Em $1980^{66}$ foi constituída uma comissão mista para promover estudos relativos ao estabelecimento de sistema de microfilmagem de processos administrativos e em $1989^{67}$, foram nomeados os membros da comissão para estabelecer normas para a eliminação de processos administrativos microfilmados.

Ao contrário das comissões anteriores, constituídas por representantes das Secretarias do Governo, Planejamento, Finanças e Assuntos Judiciários, esta comissão tinha representantes de todas as secretarias da administração, sendo que pela Secretaria de Educação e Cultura, uma das representantes era também chefe do Serviço de Documentação e História Local. Foi proposto aos representantes de todas as secretarias que elaborassem um rol de assuntos de processos que poderiam ser eliminados após os serviços de microfilmagem, conforme um formulário. Em dezembro de 1989, foi concluído o levantamento e sugerido que se preservasse três expedientes de cada espécie ou assunto. Os processos considerados passíveis de destruição foram encaminhados para o Incinerador Vergueiro.

Atendendo às solicitações do jornalista e memorialista Ademir Médici, que prestava serviços à Prefeitura de São Bernardo na época, o Secretário de Educação e Cultura, solicitou que a incineração dos processos fosse paralisada, enquanto o Serviço de História e Memória Local providenciava local para guardá-los. No processo que trata deste assunto aparece a informação que seis meses depois não haviam sido retirados.

\footnotetext{
${ }^{66}$ Portaria 6.373, de 28/01/1980, Processo Administrativo Interno $\mathrm{n}^{\mathrm{o}} 8.296 / 75$.

${ }^{67}$ Portaria 6.844, de 09/06/1989, Processo Administrativo Interno $\mathrm{n}^{\mathrm{o}} 8.296 / 75$.
} 
Este conflito entre o interesse do Arquivo Central de desocupar espaço para dar continuidade à guarda de novos documentos produzidos e a preocupação de memorialistas e responsáveis pelo Serviço de Documentação e História Local em conservar documentos que pudessem ser de "valor histórico", que ocorre também em outros municípios, indica a falta de clareza nas atividades de avaliação quanto aos documentos públicos municipais que devem ser preservados, porque e para quem, para que não se repita a dicotomia "valor administrativo/valor histórico", sem uma solução satisfatória.

Quanto ao Serviço de História e Memória Local, que em 1981 já havia assumido a custódia de grande quantidade de processos administrativos a serem destruídos, defendia que antes da incineração os processos deviam passar por uma triagem técnico-especializada.

Por outro lado foram viabilizadas algumas ações no sentido de ampliar a discussão e buscar soluções:

- de 11 a 22 de setembro de 1989, foi realizado por iniciativa do SDHL- Serviço de Documentação e História Local, da Secretaria de Educação e Cultura, o curso "A Importância do Acervo Arquivístico Municipal", ministrado pela então diretora do Arquivo Municipal de São Paulo, Daíse Apparecida de Oliveira. Ao final do curso, uma Carta de Intenções foi redigida prevendo a criação de Comissões Setoriais e de uma Comissão Central de Avaliação.

- no Seminário sobre Patrimônio Cultural de São Bernardo do Campo, realizado no Teatro Martins Pena, nos dias 2, 3 e 4 de maio de 1990, foi convidada para proferir uma palestra sobre "A importância do Patrimônio Documental", a mesma Diretora do Arquivo Histórico Municipal de São Paulo.

Tendo a legislação de São Paulo como modelo, foi elaborada a Minuta de decreto $\mathrm{n}^{\circ}$ SJ.121 - 19/91 que "estabelece normas de avaliação e destinação para os documentos da Administração Pública do Município de São Bernardo do Campo, e dá outras providências." A análise deste 
documento evidencia que o Arquivo Central passava a constituir uma espécie de Arquivo Intermediário e que como não estava prevista a criação de um Arquivo Público Municipal, o Serviço de Documentação e História Local, assumia suas atribuições, pois conforme o artigo $9^{\circ}$, "Os documentos de valor probatório ou cultural, sem vigência definida e com evidente interesse público serão transferidos para o Serviço de Documentação da História Local, nos prazos estabelecidos nas tabelas de temporalidade". Era constituída uma Comissão Central de Avaliação de Documentos, vinculada ao mesmo Serviço (artigo 11) com atribuições como: propor critérios de racionalização e controle de produção de documentos; definir critérios de valoração de documentos destinados à preservação do patrimônio documental do Município; elaborar e propor à aprovação as tabelas de temporalidade previstas neste decreto, entre outras.

Quanto a esta proposição já mencionamos anteriormente a relevância de que o órgão encarregado da gestão sistêmica dos documentos de arquivo da administração municipal fique de preferência junto ao gabinete do Prefeito, em posição hierárquica que lhe permita relacionar-se com todas as unidades orgânicas da administração, e estabelecer as normas e diretrizes necessárias.

Até 1992, último ano desta gestão houve tentativas por parte do Secretário da Educação e Cultura e dos responsáveis pelo Serviço de Documentação e História Local de encaminhar e viabilizar esta proposta. Como isto não se deu, o processo foi arquivado. ${ }^{68}$

O Serviço de Arquivo e Microfilmagem microfilma praticamente todos os processos, persistindo a preocupação em conservar os documentos históricos. Por isso, a Secretaria de Governo a qual está subordinado este serviço, considerou,

\footnotetext{
${ }^{68}$ Processo Administrativo Interno $\mathrm{n}^{\mathrm{o}}$ 12.675/90.
} 
"o trabalho de avaliação da relevância histórica dos documentos constantes dos processos administrativos, pela sua natureza técnicaespecífica torna a presença de funcionários do Departamento de Cultura indispensável junto ao Serviço de Microfilmagem, para que possa se efetuar a destruição dos processos que não forem de valor histórico evitando-se a paralisação das atividades do Serviço de Arquivo e Microfilmagem"69

Portanto, o que continuou acontecendo foi a prática de após a microfilmagem dos processos, funcionários do Serviço de Memória e Acervo serem chamados para avaliar os "processos de interesse histórico" recolhidos a seguir por este órgão. Indagados quanto aos critérios utilizados para a avaliação e seleção destes documentos, chefias e funcionários encarregados desta atividade, indicaram a dificuldade de chegar-se a um consenso sobre o que selecionar: como realizam esta atividade em uma espécie de rodízio e não há critérios claros estabelecidos, a escolha frequentemente é baseada no "bom-senso" e na subjetividade. O serviço aponta ainda o fato de não possuir um historiador no seu quadro de funcionários.

\subsubsection{3 - São Caetano do Sul}

Não tivemos acesso aos documentos que registram as atividades de avaliação de documentos em São Caetano do Sul. Funcionários ligados aos serviços de História e Memória do município informaram ter participado de comissões de avaliação, nos anos de 1996/1997 e as responsáveis pelo Serviço de Protocolo e Arquivo da Diretoria da Administração e pelo Serviço de Microfilmagem da Diretoria da Fazenda também manifestaram seu interesse no processo de avaliação, devido ao acúmulo de documentos. Como mencionamos anteriormente, mesmo tendo localizado o número do

\footnotetext{
${ }^{69}$ Memo 1.113/98, Processo Administrativo Interno no $9627 / 73$.
} 
processo que trata do assunto, e o local onde se encontrava, não tivemos acesso ao mesmo ${ }^{70}$ para analisar os estudos feitos à respeito, a constituição das comissões, seu funcionamento ou dificuldade de funcionamento.

Por outro lado o Processo Interno $n^{\circ} 3.700 / 03$, aberto a partir das solicitações do Ministério Público sobre informações à respeito da instituição do arquivo público municipal, recupera documentos anteriores sobre o assunto. Por exemplo, em 1997, foi encaminhado à Câmara Municipal o projeto de Lei que "dispõe sobre o Patrimônio Arquivístico de São Caetano do Sul instituindo o Arquivo Público Municipal e o Sistema Municipal de Arquivos e dá outras providências"71. Este projeto estabelecia:

- artigo $1^{\circ}$ - Cabe a Fundação Pró Memória de São Caetano do Sul, a proteção e a guarda do patrimômio arquivístico do Município.

- artigo $2^{\circ}$ - Fica criado o Arquivo Público Municipal, dentro da estrutura interna da Fundação, da qual será uma Divisão.

Quanto à questão da avaliação documental, previa o artigo $8^{\circ}$, a criação de uma Comissão de Análise de Documentos de Arquivo, convocada pelo Conselho Diretor da Fundação Pró-Memória e constituída por: dois representantes da Fundação Pró-Memória, um representante da Diretoria da Administração, um representante da Diretoria de Assuntos Judiciários, um representante da Câmara Municipal.

Aqui também se percebe a ausência da dimensão do volume, variedade e especificidades da documentação pública do município, da necessidade de uma assessoria para a realização de uma avaliação científica conforme os preceitos da Arquivística.

\footnotetext{
${ }^{70}$ Segundo o Serviço do Protocolo o processo interno mencionado é o de $\mathrm{n}^{\circ}$ 379/92, encontrando-se na Diretoria de Assuntos Jurídicos. Após inúmeras tentativas, sempre com a justificativa de que não fora encontrado, desistimos de consultá-lo.

${ }^{71}$ Oficio GP 243, de 13 de março de 1997, Processo 5356/97.
} 
O projeto entretanto, não chegou a ser votado e viabilizado, apesar de ter ganho destaque na imprensa da região. Com a manchete "São Caetano ganha centro de documentação e arquivo - Fundação Pró-Memória cria projeto de com verba de $\mathrm{R} \$ 85$ mil conseguida via Lei de Incentivo a Cultura", o Diário do Grande ABC, do dia 25 de julho de 1997, noticiava,

"O presidente da Fundação orgulha-se do fato de a instituição que comanda ter sido a única do Grande $A B C$ a receber apoio da Lei de Incentivo a Cultura. Assegura também que o arquivo municipal é o primeiro a ser criado na região.

'Estamos colocando a mão sobre o arquivo morto da Prefeitura que conta toda a história do município'. Na verdade, nem tudo será aproveitado visando a catalogação.

'É preciso selecionar o arquivo, constatar o que é relevante, fazer uma prospecção e, então, organizá-lo', explica."

\subsubsection{4 - Diadema}

Em Diadema, 12 anos após sua emancipação, a Portaria $n^{\circ}$ 8/72 aprovava um Manual do Setor de Protocolo e Arquivo, ${ }^{72}$ visando "a elaboração do arquivo e o controle dos documentos em geral", dividido em três partes, apresentação do sistema, regulamentação, e descrição das fichas e formulários necessários aos registros e controles, e da rotina necessária ao funcionamento do sistema. Afirmando a "importância do arquivamento de documentos e papéis para a Administração Municipal”, o manual apontava como razões para o estabelecimento do Arquivo:

a) incrementar a eficiência do governo municipal

\footnotetext{
${ }^{72}$ Este manual foi produzido pela empresa GPI - Grupo de Planejamento Integrado Ltda., contratada para modernização administrativa da prefeitura.
} 
b) preservar os recursos culturais representados pelos documentos oficiais

c) proteger os direitos pessoais e os privilégios estabelecidos por documentos oficiais

d) e exercer a tarefa do governo

Manifestava a preocupação com a documentação acumulada, com a "desobstrução dos documentos relegados aos desvãos menos freqüentados" e mencionava a necessidade da "elaboração de Planos de Destinação regular e sistemática dos documentos oficiais e comportar possíveis serviços para a reparação dos documentos danificados, para a microfilmagem de documentos e para a armazenagem dos mesmos sob condições físicas apropriadas."

Esta mesma portaria além de aprovar o Manual de Arquivo estabelecia a constituição da Comissão de Avaliação e Controle de Documentos - CACD, que foi instalada e iniciou seus trabalhos neste mesmo ano. Nesta época, a Chefe do Serviço de Arquivo e Protocolo oficiou ao prefeito pedindo que nomeasse a comissão dada a necessidade de eliminação de documentos Esta primeira comissão era constituída pelo Diretor de Administração, João Pellegrini, como presidente executivo, pela Chefe do Serviço de Protocolo e Arquivo, Marley Amadeu Paes, como secretaria, e de Glória Marina Hahüel, Tadashi Tsutui e Aparecida Palmeira Lopes, funcionária deste Serviço.

Em 1974, após consulta ao Departamento Jurídico feita pelo novo Diretor de Administração, Dr. Mário Franco Bittencourt, quanto a eliminação dos documentos públicos avaliados como inservíveis, foi comprada uma fragmentadora.

No dia dez de dezembro de 1979 um ofício do Diretor de Administração, sr. Emílio Bonani Neto, propõe ao prefeito "instituir uma comissão especial, composta por Secretários de Finanças, Administração e 
Jurídico, Projetos e Controle, Divisão de Contabilidade, Setor de Protocolo e Arquivo e da Procuradoria, para julgar os papéis que não oferecem interesse algum para o Arquivo, haja vista sua inutilidade, bem como avaliar os papéis considerados documentos para os fins dos Serviços de Microfilmagem e por final, apontar um programa de trabalho". Acrescenta ainda que, "para facilitar o trabalho da Comissão, preparamos um índice geral dos documentos mantidos atualmente no arquivo morto". Concordando com as ponderações o prefeito estabeleceu um prazo máximo de 60 dias para a entrega final dos trabalhos, a serem posteriormente submetido a apreciação de uma auditoria externa independente (João Angélico S/C Ltda).

Nessa época, como vimos, havia uma proposta de microfilmagem de documentos da administração que será detalhada no ítem seguinte deste trabalho.

No ofício 01/90, a Chefe do Serviço de Protocolo e Arquivo solicitava novamente ao Diretor do Departamento de Administração, estudos para a criação de "uma Comissão para Avaliação de Processos e Documentos, os que deviam ser eliminados após estudo quanto ao valor administrativo legal e/ou fiscal e o valor de memória da administração". É a primeira vez que encontramos referência a este último critério quanto a avaliação de documentos.

Ainda em 1990, quando da discussão da Reforma Administrativa, técnicos da Fundação do Desenvolvimento Administrativo- Fundap, foram contratados pela administração e um deles elaborou um diagnóstico, com várias propostas para os arquivos da prefeitura. ${ }^{73}$ No documento esclarecee não ter sido possível avaliar o conjunto da documentação produzida, mas somente o protocolo, o arquivo de processos e o arquivo de fotografias. Fez várias sugestões de caráter prático para o funcionamento do protocolo e do

\footnotetext{
${ }^{73}$ Rose Marie Inojosa. Prefeitura Municipal de Diadema. Arquivo: Análise de situação e sugestões. Janeiro de 1990. Acervo Centro de Memória de Diadema.
} 
arquivo, inclusive a partir de sua informatização. Partindo dos objetivos, esclarece neste documento que,

"O Arquivo de uma organização tem duas finalidades básicas. A primeira é funcionar como suporte/meio das relações de comunicação e os cidadãos e entre as partes internas da organização. A outra finalidade é constituir a memória desta organização e das suas sucessivas gestões".

Considerando o caráter orgânico do arquivo apontou para a necessidade de se estabelecer soluções para todo o sistema e não para partes do mesmo. Assim, mais adiante propôs,

\begin{abstract}
"Para organizar o Arquivo da Prefeitura de Diadema nessa perspectiva de contemplar suas duas finalidades, seria preciso repensar o sistema como um todo, no bojo do processo da reforma administrativa, que constitui uma ótima oportunidade para isso. Nesse sentido, na reestruturação ou redefinição dos departamentos, e a partir da explicação de suas funções, já se determinaria que séries documentais cada unidade geraria, qual a sua tramitação, de modo a eliminar passos desnecessários e agilizar o andamento de documentos e o destino de cada conjunto de documentos: eliminação ou arquivamento, com a determinação de prazos de guarda."
\end{abstract}

Propunha portanto que paralelamente à reforma administrativa fossem estabelecidos os procedimentos de classificação e avaliação. ${ }^{74}$

A maior parte das mudanças que sugeriu para práticas que observou, não ocorreram, persistem até hoje por exemplo, a classificação e guarda dos

\footnotetext{
${ }^{74}$ Esta proposta poderia ter sido posta em prática em 1995, na gestão seguinte, quando foi feita uma grande reforma administrativa. Mas isto não ocorreu. Aliás, é interessante observar que os decretos e portarias que deviam complementar a LC $\mathrm{n}^{\mathrm{o}}$ 0036/1995, que instituiu a reestruturação administrativa, estabelecendo as funções dos vários serviços e departamentos criados não foram feitos, com exceção dos relativos à Secretaria de Finanças, nos últimos meses desta administração.
} 
processos pelo critério numérico-cronológico, a ausência de controle dos processos que saem do arquivo e não retornam, etc.

Quanto ao Arquivo de Fotografias acreditamos que o documento citado faz referência às fotos que mais tarde constituíram o acervo do Setor de Comunicação, e que em sua grande maioria foram para o Centro de Memória da cidade, como relatamos anteriormente. Além das sugestões para o armazenamento e de fichas de referência para recuperação das fotos, também foi proposto:

\begin{abstract}
"Fundamentalmente, porém, é preciso estabelecer um programa de trabalho para o fotógrafo, estabelecendo, além da documentação de eventos, uma programação regular de documentação de obras públicas, de funcionamento de unidades da administração e de transformações urbanas, dependentes ou independentes da ação da Prefeitura."
\end{abstract}

Conversamos com o Diretor de Administração na época e segundo o mesmo, as discussões e esforços para empreender a reforma administrativa terminaram ocupando praticamente todo o seu tempo ${ }^{75}$, não tendo podido encaminhar as propostas feitas. Mas, atendendo as solicitações da Chefe do Serviço de Protocolo e Arquivo, que reiterava a necessidade de eliminar documentos sempre pela questão da inexistência de espaço para acomodá$\operatorname{los}^{76}$ solicitou aos vários Departamentos (hoje Secretarias) que nomeassem seus representantes para uma Comissão de Avaliação de Documentos. Todos os Departamentos o fizeram, com exceção do Departamento de Negócios Jurídicos. Apesar dos reiterados pedidos, este departamento alegou sempre que não havia pessoas disponíveis (no dia 08 de agosto de 1990, declara, "não sendo de caráter urgente, sugiro que o trabalho seja

\footnotetext{
${ }^{75}$ Esta Reforma Administrativa não se efetivou, o prefeito não tinha maioria na Câmara Municipal e apenas alguns ítens da mesma conseguiram ser aprovados.

${ }^{76}$ Ofício n $^{\circ} 01 / 90$, Processo Interno $n^{\circ} 8.112 / 90$.
} 
suspenso temporariamente, até que possamos dispor de um advogado para este fim").

Sem conseguir um representante da área jurídica até o final desta gestão, a comissão não se reuniu e no dia 14 de dezembro de 1992, o Diretor do Departamento de Administração encaminhou o processo para arquivamento $^{77}$.

Esta preocupação foi retomada em 1993, quando o chefe da Divisão de Documentação solicitava a instituição de uma comissão para "expurgo de grande parte de papéis arquivados, alguns com mais de 30 anos para desocupar e receber novos em seu lugar." Apesar dos vários despachos solicitando que as secretarias indicassem com urgência seus representantes para esta comissão, o processo de indicação durou aproximadamente um ano sem que fosse concluído. E em 28 de agosto de 1994, a chefe da Divisão de Documentação e Serviços Gerais e presidente da comissão determinou "o arquivamento do expediente até que os trabalhos da comissão se iniciassem". Questionada sobre o não funcionamento da Comissão de Avaliação, declarou que optaram pela resolução de outras questões como organização do protocolo, a questão da informatização e a resolução do problema do espaço para a guarda da documentação, já que a mesma teve que ser transferida do Paço para dar lugar a outro setor. Indagada sobre a contratação de técnicos ou assessorias para orientar o trabalhos da comissão, explicou que haviam sido feitas visitas e pesquisa na legislação de cidades que já possuíam arquivos organizados, como São Paulo e Santos. Confirmou que a preocupação no momento era resolver o problema da eliminação de documentos devido ao problema de espaço, mas por sua formação em História pensava a longo prazo na instituição do Arquivo Histórico, com a guarda da documentação de caráter permanente.

Até o final desta gestão (1993-1996) a comissão de avaliação não foi instalada.

\footnotetext{
${ }^{77}$ Processo Administrativo Interno $\mathrm{n}^{\mathrm{o}} 8.112 / 90$.
} 
O que se percebe pelas Atas referentes à fragmentação de documentos, é que na prática, de 1972 a 1993, apesar das propostas e tentativas de instalação de comissões de avaliação de documentos, o Serviço de Arquivo encaminhava relações dos documentos que guardava às chefias dos Departamentos e Serviços, e estes autorizavam sua destruição. Ou os documentos eram encaminhados para o Serviço já com autorização para destruição. Documentos produzidos pelo o Serviço de Protocolo e Arquivo (correspondência, projetos, etc.) também evidenciam que até este momento o Serviço de Arquivo era considerado como um depósito de documentos.

O processo referente a avaliação de documentos foi reaberto em 1997, ainda devido a preocupação com acúmulo da massa documental e a dificuldade da administração de ter local para sua guarda. Em 1998 ocorreu a $1^{a}$ reunião da CADOC-Comissão de Avaliação de Processos e Documentos. $\mathrm{Na}$ ocasião, os funcionários do Centro de Memória de Diadema, que representavam a SECEL-Secretaria de Educação, Cultura e Esportes, alertaram para a necessidade de se contratar uma assessoria para orientar e acompanhar os trabalhos de avaliação dos documentos, o que não ocorreu. As chefias do Departamento de Serviços Gerais e Documentação e do Serviço de Arquivo e Microfilmagem elaboraram a minuta do Decreto que disciplinaria a avaliação e destinação dos documentos, e a apresentaram aos integrantes da comissão, no dia 11 de setembro de 1998. A leitura e análise da mesma evidenciam a grande influência do Decreto 29.745, de 14 de maio de 1991, da Prefeitura Municipal da cidade de São Paulo, feitas algumas adaptações. Ocorre que no município de São Paulo existe um Arquivo Histórico Municipal, o que não acontece em Diadema. Portanto, a questão da destinação dos documentos de caráter permanente, e a aprovação dos editais de eliminação ficaram prejudicados. Isto porque, apesar de ter como modelo o decreto de São Paulo, o principal objetivo dos que propuseram 
esta comisssão era como anteriormente, eliminar documentos resolvendo o recorrente problema de espaço para conservá-los.

No dia 24 de maio de 1999, com algumas das alterações propostas pela comissão, e após parecer da Secretaria de Assuntos Jurídicos, foi instituído o Decreto $n^{\circ}$ 5.162, alterado pelo Decreto 5.192/99 ${ }^{78}$, que estabelecia a criação de uma comissão permanente de avaliação de documentos, seu funcionamento, os critérios para eliminação de documentos e o modelo de Tabela de Temporalidade.

Como dado positivo desta Comissão temos o fato de ter funcionado regularmente até o início do ano de 2000. A comissão trabalhou com amostras coletadas dos documentos que estavam em um depósito do Serviço de Arquivo. Se por um lado isto permitiu conforme o objetivo da comissão que se eliminasse uma quantidade significativa de documentos de acordo com as Tabelas de Temporalidade, por outro lado, como as mesmas foram elaboradas a partir de documentação acumulada e não da produção dos vários órgãos, as Tabelas não refletiam efetivamente todas as funções e atividades dos órgãos. Daí a dificuldade de serem utilizadas posteriormente pelos setores na destinação de seus documentos.

Foram publicadas uma tabela geral de temporalidade (Tabela PMD 01/99) relativa a documentos utilizados pelas diversas secretarias (como autorização de horas-extras, guia de remessa de correspondência,etc.), tabelas para documentos das Secretarias de Administração (menos para os setores de Compras e Recursos Humanos), Serviços Urbanos (distribuição da frota, abastecimento, divisão de trânsito, transportes públicos, limpeza urbana, iluminação) e Finanças (todos os setores). Também foi aprovada uma tabela de temporalidade de processos externos com 52 tipos de assuntos. Foram publicados editais de eliminação e fragmentados aproximadamente 41.000 metros lineares de documentos.

\footnotetext{
${ }^{78}$ Conforme esta alteração ao invés do prefeito, quem autorizava a eliminação dos documentos era o Secretário de Administração.
} 
Com relação a eliminação dos documentos lembramos que segundo o artigo $9^{\circ}$ da Lei 8.159/91, Lei de Arquivos, "A eliminação de documentos produzidos por instituições públicas e de caráter público será realizada mediante autorização da instituição arquivística pública, na sua específica esfera de competência", e no caso do município de Diadema, não foi criado por lei e instalado o Arquivo Público Municipal, instituição arquivística que deveria autorizar a eliminação.

Ainda com relação a destinação dos documentos, ao se proceder a elaboração das tabelas e determinação de seus prazos de guarda, um problema também relacionado a não existência do Arquivo Público Municipal apareceu: quem teria a custódia dos documentos considerados de guarda permanente?

$\mathrm{Na}$ primeira versão do decreto que estabelecia a Cadoc e as normas de avaliação e destinação de documentos, a destinação prevista para estes documentos era o Centro de Memória da cidade. Como os integrantes do Centro de Memória, que participavam desta comissão deixaram clara a diferença entre sua instituição e um Arquivo Público Municipal, declarando que não poderiam receber todas estas séries documentais, a menção ao destino dos documentos de caráter permanente foi retirada tanto do decreto 5.162/99, quanto das Resoluções 01/99 e 02/9979, determinando apenas onde ficariam os documentos caracterizados como dos arquivos correntes e os do arquivo intermediário.

Por isso afirmamos que mais uma vez a preocupação era eliminar documentos, resolvendo o problema do espaço ocupado por eles, ainda que buscassem critérios.

Também por iniciativa da presidente da comissão estabeleceu-se a simplificação de vários procedimentos, diminuindo o número de situações que davam origem a formação de processos. Um dos fatores determinantes

\footnotetext{
${ }^{79}$ Estas Resoluções da Secretaria da Administração e da Comissão de Avaliação de Processos e Documentos, aprovavam Tabelas de Temporalidade e estabeleciam a destinação final dos documentos.
} 
da viabilização de todas estas ações foi o fato de um dos membros da Comissão em sua primeira fase ter sido algum tempo depois nomeada Secretária da Administração. Nesta altura já tinha entendimento do que se pretendia e da importância de referendar as ações nesse sentido.

No final de 2000, as eleições municipais trouxeram a vitória de novo partido, e consequentemente em 2001 as chefias nos vários níveis foram substituídas.

Mesmo que algumas delas cogitassem de convocar novamente a comissão de avaliação de documentos, pensavam em substituir a denominação CADOC, considerada uma "marca" da administração anterior. Mas, durante toda a gestão $2000-2004$, não foi nomeada a comissão, apesar do Decreto 5.162/99, ter estabelecido que a mesma é permanente e do decreto não ter sido revogado.

O que o Serviço de Arquivo e Microfilmagem tinha proposto do início da gestão até julho de 2003, está descrito em um documento de uma página com o título de "Arquivo Permanente" (sic) que apenas aponta de forma genérica algumas ações a serem desenvolvidas, como a implantação de microfilmagem, modernização dos serviços, reestruturação da CADOC e criação de espaço permanente para a guarda e exposição de documentos históricos (sic). ${ }^{80}$

No ano de 2003, uma funcionária transferida do Departamento de Cultura para este setor, realizou uma série de reuniões e discussões com os funcionários do Serviço de Arquivo e sua chefia e elaborou um Projeto de Sistema de Arquivos e instituição de Arquivo Público Municipal. Este projeto não foi encaminhado, pois o interesse na época era uma solução rápida para os documentos acumulados e em processo de destruição no galpão anexo ao Arquivo e a liberação de espaço para acomodar os processos. Por isso consultou-se um empresa para terceirizar os serviços, outra que se propunha a organizá-los e afinal optou-se por uma solução "doméstica", o Projeto

\footnotetext{
${ }^{80}$ Grifo nosso.
} 
Extra, aproveitando alguns itens propostos pelo projeto de instituição do Sistema de Arquivos e outros da empresa que se propunha a organizar os documentos, a chefia do serviço propôs que os próprios funcionários do serviço (e os da gráfica da prefeitura que trabalham em local contíguo) trabalhando após seu horário normal, daí o nome "extra", retirassem os documentos remanescentes do galpão anexo ao arquivo de processos, higienizando-os e acondicionando-os.

Aqui lembramos as considerações de Lopes (2002),

"O patrimonialismo arquivístico, bastante difundido no país, implica que, comumente, os arquivistas e administradores entendam o investimento físico - instalações, mobiliário, embalagens, etc. - como principal e único tratamento a ser dado aos arquivos. (...) O tratamento intelectual, isto é, a classificação, a avaliação e a descrição ficam para depois, quando não são esquecidos ou praticados de modo enviesado".

O certo é que durante toda esta gestão, não houve avaliação de documentos. Entretanto, no dia 28 de agosto de 2003, foi publicado o Edital de Ciência de Eliminação de Processos e Documentos $n^{\circ} 1 / 2003$, assinado pelo Secretário de Administração. Lembramos mais uma vez que não existe no município, instituição arquivística pública que autorize esta eliminação, e que conforme a Resolução CONARQ-Conselho Nacional de Arquivos $\mathrm{n}^{\circ}$ 7/97, a Listagem de Eliminação de Documentos deve ser assinada pelo Presidente da Comissão Permanente de Avaliação de Documentos, que não foi constituída. 


\subsubsection{5 - Mauá, Ribeirão Pires, Rio Grande da Serra.}

As informações prestadas pelos responsáveis pelos Serviços de Protocolo e Arquivo de Mauá atestam a inexistência até a última gestão municipal (2001-2004) de atividades de avaliação no município.

$\mathrm{Na}$ entrevista que realizamos com a Secretária da Administração na época (2003), esta manifestou seu interesse na criação do Arquivo Público Municipal e um Sistema de Arquivos. Segundo a mesma nos primeiros anos do governo, a grande demanda da administração era pela informatização e os recursos foram investidos neste sentido. Outra iniciativa durante sua gestão foi com relação aos processos de trabalho, onde a secretária incluía a questão da guarda e gerenciamento dos documentos. Mesmo reconhecendo que esta devia ser a primeira tarefa, teve que iniciar pela informatização.

Não conseguindo liberação dos recursos do PNAFM-Programa Nacional de Apoio à Gestão Administrativa e Fiscal dos Municípios Brasileiros, voltado para a gestão administrativa e fiscal, que permitiria viabilizar o projeto, procurou outras agências financiadoras como o Programa ADAI - Programa de Apoyo al Desarollo de Archivos Iberoamericanos, sem sucesso. A estratégia seguinte foi propor às secretarias-meio que funcionavam junto a Secretaria da Administração, Finanças e Negócios Jurídicos, uma espécie de projeto-piloto, para organizar e posteriormente avaliar a documentação destas secretarias. Na época em que foi realizada a entrevista (2003), estavam identificando e higienizando a documentação. Pretendia a partir do resultado obtido sensibilizar as outras secretarias. Sua saída, no último ano da administração para assumir a Secretaria da Saúde, prejudicou o andamento do processo.

Em Ribeirão Pires, não há registro de funcionamento de atividades de avaliação de documentos, entretanto a Lei 4.681/03 que criou o Centro de Apoio Técnico ao Patrimônio estabelece entre as atribuições do órgão, em seu artigo $2^{\circ}$, ítem VIII - Participar de comissão de avaliação de 
documentação no Município e da organização de arquivos municipais (Câmara Municipal, Cartórios, Prefeitura, Delegacia de Polícia, Fórum, Hospitais, Empresas, Escolas, Sindicatos, Igreja, Jornais, etc.).

Aqui é interessante notar que não houve por parte dos responsáveis pela elaboração do mesmo e pela Secretaria dos Assuntos Jurídicos, se a mesma apreciou o projeto, respeito às competências e jurisdições dos respectivos arquivos.

No município de Rio Grande da Serra não encontramos nenhuma iniciativa relacionada com avaliação de documentos.

\subsection{2 - Microfilmagem}

A microfilmagem ${ }^{81}$ dos documentos produzidos e acumulados pela administração pública foi, como as tentativas de avaliação de documentos, uma forma pragmática de tratamento dos mesmos. Os documentos consultados e os depoimentos de funcionários das administrações evidenciam que a grande preocupação era com o espaço ocupado pelo volume crescente da documentação, ainda que a questão da segurança também tivesse sido apontada, em algumas situações.

O Dicionário de Terminologia Arquivística (1996) aponta cinco finalidades para o uso do microfilme: microfilmagem de complemento, de preservação, de referência, de segurança e microfilmagem de substituição. Seriam estas duas últimas, as utilizadas pelas administrações que estudamos:

- a microfilmagem de segurança em geral é praticada por toda instituição pública ou privada, cultural ou administrativa, para assegurar a preservação da informação na ocorrência de algum sinistro com o arquivo de

\footnotetext{
${ }^{81}$ Microfilmagem é a produção de imagens fotográficas de um documento, em tamanho altamente reduzido (Camargo \& Bellotto, 1996).
} 
microfilmes. Após a revelação e inspeção do filme master (matriz), é gerada uma cópia idêntica, responsável pela produção das demais cópias.

- quanto a microfilmagem de substituição, sua principal função é ganhar espaço, sendo realizada em documentos de arquivos administrativos com valor temporário. Também pode ser aplicada a documentos cujos suportes estejam muito deteriorados, sem possibilidades de restauração, o que acontece frequentemente com periódicos. Neste caso, o original é substituído pelo microfilme de forma permanente.

No Brasil, a partir da segunda metade do anos 60 os processos de microfilmagem começaram a ser adotados em empresas e nas instituições governamentais, mas foi sobretudo a partir dos anos 70 que esta prática se tornou mais freqüente. Isto fez com que houvesse necessidade de legislação regulamentando estas ações e também provocou o interesse dos profissionais da área de arquivos no assunto. Assim é, que no I Congresso Brasileiro de Arquivologia, promovido pela recém fundada Associação dos Arquivistas Brasileiros, que aconteceu no Rio de Janeiro, de 15 a 20 de outubro de 1972, o tema "microfilmagem" foi objeto de seis apresentações, em diferentes sessões, sempre com muitas questões propostas aos expositores, conforme registram os Anais deste congresso.

Abordando a questão da avaliação dos documentos, Nilza Teixeira Soares em uma das sessões do mesmo, assim referiu-se a microfilmagem,

\footnotetext{
"Quando se esgotam os espaços físicos reservados à guarda de arquivos, procuram-se soluções que não primam muitas vezes pela lógica e racionalização. Os problemas não são devidamente equacionados, e a solução a que se recorre mais prontamente, é a microfilmagem, já que o problema é colocado em termos de recuperação de espaço. (...) A Lei $n^{\circ} 5.433$ veio estimular o emprego desse recurso, não sendo de todo conhecido o verdadeiro espírito dessa lei, que foi sobretudo o de oferecer condições probantes à microcópia, como se reconheceu, pelo art. 138, do Código Civil (...) e posteriormente, o
} 
Decreto-Lei $n^{\circ}$ 2.148, de 1940, que acompanhando a evolução dos processos de reprodução de documentos, em seu artigo $2^{\circ}$ atribuiu valor de prova em juízo, 'às certidões de inteiro teor extraídas por fotocópia, desde que declaradas conforme o original'."

Ainda sobre a origem da Lei 5.433/68, esclareceu,

"O Regulamento do Serviço Geral e Arquivo da Aeronáutica, aprovado pelo Decreto 1.976, de 25 de janeiro de 1963, autorizou a adoção desse processo de reprodução de documentos para uso de suas repartições, e a chamada Lei de Microfilmagem resulta de proposta do Ministério do Exército ao Ministro da Justiça que preparou a exposição de motivos e justificou o citado projeto de lei."

Assim, constituíram marcos legais para os processos de microfilmagem, inicialmente a Lei 5.433/68, de 8 de maio de 1968, regulamentada pelo Decreto $n^{\circ}$ 64.398, de 24 de abril de 1969. Este foi substituído pelo Decreto $n^{\circ} 1.799$, de 30 de janeiro de 1996, atualizando a regulamentação da Lei de Microfilmagem ${ }^{82}$.

Com relação a nosso objeto de estudo destacamos neste decreto que continua em vigor:

Artigo 12 - A eliminação de documentos após a microfilmagem, darse-á por meios que garantam sua inutilização sendo a mesma precedida de lavratura de termo próprio e após a revisão e a extração de filme cópia.

Parágrafo único - A eliminação de documentos oficiais ou públicos só deverá ocorrer se a mesma estiver prevista na tabela de temporalidade do órgão, aprovada pela autoridade competente na esfera de atuação do mesmo e respeitado o disposto no artigo $9^{\circ}$ da Lei $n^{\circ} 8.159$, de 08 de janeiro de 1991.

\footnotetext{
${ }^{82}$ Além disso, a Portaria ${ }^{\circ} 58$ do Ministério da Justiça, de 20 de junho de 1996, dispõe sobre a fiscalização do exercício da atividade de microfilmagem de documentos oficiais, obrigando a todos que se utilizam desses serviços a se cadastrarem no Ministério da Justiça e a Resolução Conarq ${ }^{\circ}$ 10/99, dispõe sobre a adoção de símbolos ISO nas sinaléticas a serem utilizadas no processo de microfilmagem de documentos arquivísticos.
} 
Artigo 13 - Os documentos oficiais ou públicos, com valor de guarda permanente, não poderão ser eliminados após a microfilmagem, devendo ser recolhidos ao arquivo público de sua esfera de atuação ou preservados pelo próprio órgão detentor.

\title{
4.2.2.1 - Santo André
}

O Serviço de Microfilmagem pertence, juntamente com o Serviço de Arquivo, à Gerência de Apoio Administrativo. Não há neste serviço um histórico do mesmo. Mas a pesquisa a publicações administrativas aponta como início das atividades de microfilmagem, o ano de 1979. Com o título, Para preservar os documentos oficiais, a microfilmagem, encontramos na publicação “Uma administração voltada para o ano 2000"83.
"Aperfeiçoando e organizando a estrutura funcional da prefeitura a administração Lincoln Grillo criou, em 1979, a Seção de Microfilmagem e Documentação. Quantos arquivos seriam precisos para a acomodação de 457 mil documentos? Hoje eles ocupam, na Seção de Microfilmagem, o espaço de duas gavetas. Pelo processo de microfilmagem não só é possível reduzir um documento em até 42 vezes, como conservá-lo intacto."

Uma publicação semelhante, de 1981, afirmava ao lado de fotos dos equipamentos:

\begin{abstract}
"Arquivar documentos não representa mais problema para a Prefeitura de Santo André. Graças a criação do serviço de microfilmagem, implantado nesta administração, os processos que antes ocupavam uma sala de 20 metros quadrados, hoje, podem ser guardados numa simples
\end{abstract}

\footnotetext{
${ }^{83}$ Esta publicação de 1982 é uma espécie de prestação de contas, com as realizações do prefeito nos cinco anos de sua gestão, 1979-1982.
} 
gaveta. O microfilme é capaz de reduzir até 27 vezes, num filme de 16 milímetros, qualquer documento. Além de facilitar o arquivamento, reduzir o espaço ocupado por papéis e diminuir consideravelmente o risco de deterioração pelo manuseio, a microfilmagem proporciona segurança e rapidez de reprodução, baixo custo de manutenção e facilidade de acesso à documentação."

A utilização da microfilmagem aparece aí como a grande e única solução para os problemas da documentação pública.

Entretanto, a constituição do Serviço de Microfilmagem nesta época, 1979, quando ainda estavam em vigor a Lei 5.433/68 e o Decreto 64.398/69, determinaram a constituição de uma comissão para julgar os documentos que poderiam ser eliminados ${ }^{84}$, já que a legislação estabelecia que "os documentos de valor histórico não deverão ser eliminados, podendo ser arquivados em local diverso da repartição detentora dos mesmos". ${ }^{85}$

Hoje com o nome de Encarregatura de Microfilmagem, as atividades continuam existindo, mas ao que pudemos constatar ${ }^{86}$ sem o investimento do início. Quando o serviço começou contava com onze funcionários, hoje, vinte e cinco anos mais tarde são apenas oito, e segundo a responsável pelo setor utiliza os mesmos equipamentos. Além dos processos selecionados para microfilmagem pelos funcionários do Arquivo Geral, microfilma outros documentos enviados por outros órgãos, como prontuários de funcionários aposentados, prontuários médicos nos casos de óbito, fichas de atendimento ambulatorial. O filme cópia fica em poder do serviço de microfilmagem e o filme matriz é guardado em condições adequadas de conservação junto ao laboratório em outro prédio.

\footnotetext{
${ }^{84}$ A constituição desta comissão, seus desdobramentos e resultados foram tratados no ítem anterior, sobre avaliação de documentos.

${ }^{85}$ Artigo $2^{\circ}$, Lei n ${ }^{\circ} 5.433$, de 8 de maio de 1968.

${ }^{86}$ Além das respostas a um questionário encaminhado ao Serviço, as informações restantes foram prestadas pela responsável do setor pessoalmente ou por telefone.
} 
Em todos os casos, o Serviço devolve a documentação para os setores que são os responsáveis por sua destinação, guarda ou destruição.

Quanto aos fundamentos legais para as ações do serviço, foram indicados a Lei $5.433 / 68$ e o Decreto $64.398 / 69$. Não houve referência ao Decreto 1.799/96, que substituiu o de 1969 e está em vigor atualmente.

\subsubsection{2 - São Bernardo do Campo}

Os estudos para microfilmagem e eliminação de documentos neste município começaram em 1973. O processo administrativo interno $\mathrm{n}^{\circ}$ 9627/73, foi aberto no dia 28 de março de 1973, pela Comissão Central de Prevenção contra Incêndio no Paço Municipal-CCPCIPM: nele seu presidente solicita em caráter de urgência a descentralização do arquivo central, bem como que se procedesse a viabilidade de instalar a médio prazo, o sistema de microfilmagem de processos.

Dando como exemplo o Serviço de Microfilmagem da Prefeitura de São Paulo, informou-se ao Diretor de Administração os equipamentos necessários para se instalar um serviço semelhante em São Bernardo ${ }^{87}$. O interesse e a disposição da administração em implantar o sistema evidenciam-se no fato de ter começado no mês de maio do mesmo ano, o processo de microfilmagem pelas fichas de Kardex (estas fichas na época eram a forma de acesso a documentação custodiada, como os processos, por exemplo).

Em 1974, o Departamento de Microfilmagem foi anexado ao ProdasbProcessamento de Dados de São Bernardo S/A ${ }^{88}$.

\footnotetext{
${ }^{87}$ O Diretor de Administração na época era o sr. Nelson Biondi, que hoje dá nome ao prédio em que está instalado o Arquivo Central, e o responsável pela microfilmagem, o sr. Beltran Ascêncio, fotógrafo conhecido pelos registros feitos da cidade e região desde os anos 60.

${ }^{88}$ A administração Geraldo Faria Rodrigues (1973-1977), criou várias empresas de economia mista, Prodasb, Protur, Prosbc, Procap e Proserv. Quando a Prodasb foi extinta, a microfilmagem passou a ser feita pelo Serviço de Arquivo e Microfilmagem da Secretaria do Governo (1989)
} 
Uma comissão mista foi constituída pela Portaria $6.373 / 80$, para promover estudos relativos ao estabelecimento da microfilmagem dos processos administrativos. Vinculada a Secretaria de Governo, era constituída por representantes da Secretaria de Assuntos Jurídicos, Secretaria de Planejamento e Economia, Secretaria de Governo e da Prodasb S/A.

Os trabalhos desta comissão subsidiaram a elaboração do Decreto 6.751/81, que "autoriza a microfilmagem de processos administrativos e dá outras providências". Nos considerandos do decreto, encontramos referência ao elevado número de processos arquivados, ao fato de muitos já não possuírem relevância que justificasse sua microfilmagem ou arquivamento, a necessidade de técnicas modernas para agilização da máquina administrativa. Este decreto previa a eliminação de processos só depois de feito o levantamento daqueles considerados "inservíveis", conforme tabela anexa.

Por outro lado, o artigo $5^{\circ}$ estabelecia: "Os documentos de interesse histórico serão relacionado e transferidos para a Secretaria de Educação, Cultura e Esportes, que decidirá sobre o destino dos mesmos".

Segundo informação do Chefe deste Serviço, foram microfilmados os processos desde a emancipação do município ${ }^{89}$ e documentos encaminhados por outras secretarias, sendo prioritária a microfilmagem de processos que tenham sido encaminhados ao arquivo e nele se encontrem sem movimentação nos últimos cinco anos. Apesar da relação anexa ao Decreto 6.751/81, permitindo destruição sem microfilmagem, constar de 69 ítens, segundo o mesmo funcionário todos os processos são microfilmados com exceção dos referentes a "rebaixamento de guia" e "revisão e aferição de hidrômetro".

\footnotetext{
${ }^{89}$ Com exceção dos processos referentes ao antigo distrito de Diadema, emancipado de São Bernardo em 1958. Por decisão da comissão que estudou a microfilmagem dos processos, estes foram encaminhados para o município de Diadema.
} 
O Serviço possui um bureau completo de microfilmagem, mas as cópias são feitas por uma empresa contratada, considerando-se esta medida mais econômica. Os microfilmes são guardados em condições adequadas de conservação neste mesmo local.

Quanto a destinação da documentação microfilmada, no caso dos documentos avulsos são devolvidos ao órgão que os encaminhou para microfilmagem, assim como as cópias dos microfilmes. Os processos administrativos microfilmados, após avaliação feita pelo Serviço de Memória e Acervo daqueles que tem "interesse histórico", são fragmentados e o resultado desta operação é destinado à Secretaria do Desenvolvimento Social e Cidadania.

Foram indicados como fundamentos legais para a realização de tais atividades os Decretos Municipais 5.589/77 e 6.751/81. ${ }^{90}$

\subsubsection{3 - São Caetano do Sul}

Como já apontamos anteriormente, em São Caetano do Sul o Serviço de Microfilmagem é subordinado a Diretoria da Fazenda ${ }^{91}$. De acordo com a responsável por ele, o primeiro passo para sua constituição foi a contratação de uma empresa especializada para fazer um Projeto Técnico de Microfilmagem: foi realizado um levantamento de toda a documentação constante dos Setores da Prefeitura, verificando seu estado geral, a quantidade, quais documentos seriam microfilmados e de que forma e, com

\footnotetext{
${ }^{90}$ Decreto Municipal $n^{\circ} 5.589 / 77$, dispõe sobre a destruição e incineração de papéis e dá outras providências e Decreto Municipal 6.751, de 18 de fevereiro de 1981, autoriza a microfilmagem de processos administrativos e dá outras providências.

91 Desde 2003, faz parte de um complexo chamado de GRAAL - Gerenciamento Reunido de Análises e Aplicativos Logísticos, que compreende um centro de processamento de dados das diretorias da administração municipal, uma área para manutenção e revitalização dos equipamentos de informática, além dos setores de microfilmagem e arquivo.
} 
base nesse levantamento, que equipamentos deviam ser adquiridos. Segundo a mesma fonte ${ }^{92}$, os objetivos do Centro de Microfilmagem eram:

1) o projeto deveria ser desenvolvido de forma a solucionar basicamente o problema de espaço ocupado pela documentação arquivada;

2) propiciar a rapidez de informação;

3) segurança da documentação.

Este serviço foi inaugurado em 28 de outubro de 1.987. Os primeiros documentos microfilmados foram as fichas de lançamento de Imposto Predial e Territorial Urbano-IPTU, do Setor de Lançadoria subordinado à Diretoria da Fazenda, do período de 1.957 à $1.984^{93}$.

Além dos processos administrativos, microfilma documentos das Diretorias da Fazenda, Administração, Educação e de Obras. Após a microfilmagem dos documentos, os filmes são processados, inspecionados, duplicados e indexados. Os filmes originais, de segurança, são mantidos em arquivo de acordo com as normas técnicas. Os filmes cópia que também são guardados neste serviço, são destinados ao fornecimento de informações quando solicitadas pelos setores (somente para funcionários).

Após a microfilmagem, os documentos são devolvidos aos setores, acompanhados de memorandos, cabendo a eles a destruição ou guarda de tais documentos. O acervo de documentos microfilmados abrange o período de 1949 a 2002 ( no que diz respeito aos processos administrativos).

\footnotetext{
${ }^{92}$ As informações sobre o Serviço de Microfilmagem foram fornecidas pela Chefia do Setor, primeiro em documento escrito, encaminhado pela Diretoria da Administração, respondendo a solicitação que fizemos e posteriormente alguns esclarecimentos foram prestados por e-mail.

93 Além do Chefe de Seção, responsável pela implantação e coordenação do Centro de Microfilmagem e supervisão dos serviços, foram contratados três preparadores de documentação, três operadores, um laboratorista e um operador para consulta e cópia e serviços de datilografia. O bureau contava com três microfilmadoras planetárias, uma processadora, uma duplicadora, um leitor copiador, um leitor para consulta,um leitor para revisão de filmes, um microscópio para garantir os testes de resolução e um densitômetro para medir a densidade dos filmes. Hoje possui também dois microcomputadores para ajudar na busca de informações, uma impressora,um desumidificador de ar para o arquivo de segurança e um ScreenScan, que escaneia as imagens já microfilmadas, passando-as para a tela do computador e possibilita digitalizar os microfilmes.
} 
O Serviço de Microfilmagem informou ainda que trabalha de acordo com a Lei Federal n 5433/68, alterada pelo Decreto n $1.799 / 96$.

\subsubsection{4 - Diadema}

Assim como nos municípios de Santo André, São Bernardo e São Caetano do Sul, a microfilmagem foi vista como uma solução para o problema do espaço ocupado pelos documentos que se avolumavam. As tratativas à respeito podem ser recuperadas através de documentos e das informações prestadas pelos funcionários ${ }^{94}$.

Em agosto de 1978, o processo se inicia com um ofício do então Diretor de Administração solicitando autorização ao Departamento Jurídico "para elaborar um decreto regulamentando a Lei 5.433/68 e o Decreto $64.398 / 69$, tendo em vista a instalação de uma máquina de microfilmagem no Arquivo Morto e considerando a necessidade de iniciarmos as operações". Como resposta, o Procurador esclareceu que leis e decretos municipais não podem regulamentar a legislação federal, e indicou a Secretaria da Fazenda do Estado de São Paulo, que desde 1969 utilizava este sistema.

A leitura dos documentos indica que a microfilmadora já estava instalada no "Arquivo-Morto" em maio de 1979, mas até o final deste ano não havia iniciado suas atividades, daí a solicitação do secretário de Administração ao prefeito para que criasse uma comissão para apontar os documentos que deviam ser microfilmados e apontasse um plano de trabalho.

Esta comissão foi composta por representantes dos Departamentos de Finanças, Administração e Assuntos Jurídicos ${ }^{95}$ e reuniu-se pela primeira vez no dia 13 de março de 1980. Não há ata desta reunião no processo. Mas

\footnotetext{
${ }^{94}$ Processo Administrativo Interno $n^{\circ} 2438 / 79$, trata da implantação de microfilmagem na Prefeitura de Diadema.

${ }^{95}$ Portaria $^{\text {o }} 7$, de 29 de janeiro de 1980.
} 
um relatório da mesma, de vinte e seis de março de 1981, considera que "em face da grande diversificação que se verifica nos documentos, papéis e processos que compõem o arquivo desta prefeitura, analisá-los sob o prisma da microfilmagem, temerário se torna definir quais os que seriam passíveis desses processos(...)". E finalmente, "entendemos inviável no momento a adoção do processo por representar dispêndio e em face da exigüidade de documentos e papéis que seriam destinados a este processo" e recomendase, "manter experimentalmente o atual dispositivo, aperfeiçoando-se o responsável."

O que se percebe da análise dos documentos é que existia uma máquina leitora e uma copiadora, mas segundo a responsável pelo Serviço, de Arquivo, para que pudessem efetivamente realizar este processo, eram necessários: uma microfilmadora para documentos de grande dimensão, uma processadora para revelar os filmes, um densitômetro, para medir a densidade de luz dos filmes, um leitor montador, para jaquetas ou outro tipo de microformas. Portanto, não se realizou anteriormente um estudo determinando tudo que era necessário para viabilizar esta atividade, nem havia um plano de microfilmagem para os documentos.

Com isto, os processos de microfilmagem foram abandonados, bem como os aparelhos e os microfilmes, declarando a responsável pelo Serviço que

"não havia necessidade de microfilmagem nos próximos anos, a não ser que visem um problema de segurança. Desocuparia muito espaço, agora e para o futuro, não acumularia documentos inservíveis se cada Setor da Prefeitura mandasse um funcionário capacitado, para apontar o que tem de ser guardado em Arquivo, por quanto tempo e o que deve ser fragmentado"

O processo foi encaminhado ao Arquivo em 1981 e não houve nas administrações seguintes nenhuma iniciativa de retomar os trabalhos, apesar 
da Lei Complementar 0036/95 ${ }^{96}$, prever em seu Capítulo II, Dos Instrumentos de Renovação Administrativa, Art. $8^{\circ}$, ítem IV,

d) a microfilmagem de documentos originais indispensáveis, de dados e referências permanentes ou de longo prazo, observados os cuidados, quando for o caso, relativos ao reconhecimento da autenticidade, eficácia ou validade jurídica do processo de microfilmagem.

e) a incineração ou destruição periódica, segundo critérios previamente aprovados em decreto, de papéis, documentos e processos desnecessários ou já microfilmados, observado, em certos casos, o prazo de manutenção da respectiva documentação, por até 5 (cinco) anos.

Só em 1997, o Departamento de Serviços Gerais e Documentação DSGD, buscando uma solução para o acúmulo de documentos, já que a administração devia desocupar o imóvel alugado para guardá-los, reabriu o processo: a primeira alternativa de solução pensada foi a microfilmagem dos documentos. Algumas iniciativas foram tomadas: solicitou-se autorização no Ministério da Justiça para realizar o processo de microfilmagem, foi feito um contato com a Empresa Kodak, para recuperação da máquina microfilmadora, foram adquiridos cento e cinqüenta rolos de filme prata. Mas um estudo mais acurado mostrou a inviabilidade da proposta, já que não havia recursos para montar um bureau de microfilmagem, e de qualquer forma seria necessário avaliar os documentos antes de microfilmá-los. Assim este Departamento após verificar como se processavam estas atividades nos municípios vizinhos e em São Paulo, tomou a iniciativa de propor a constituição da Comissão de Avaliação de Documentos e Processos CADOC.

\footnotetext{
${ }^{96}$ Dispões sobre a reorganização administrativa e a reestruturação dos quadros de pessoal da prefeitura de Diadema.
} 


\subsection{3 - O equívoco da interdependência entre avaliação e microfilmagem}

Nos ítens anteriores tratamos em separado das atividades de microfilmagem e de avaliação realizadas em alguns dos municípios do Grande ABC, buscando mostrar como em cada município se deu ou ainda se dão estas práticas. Entretanto é importante observar que o processo de avaliação de documentos foi realizado ou em função das atividades de microfilmagem ou como uma alternativa a esta, quando não se conseguia implantar o sistema, pensado como solução original para o acúmulo dos documentos produzidos e acumulados pela administração municipal.

No caso de Santo André observamos que os primeiros decretos determinando a formação de comissões de avaliação, Decreto 8.943/77 e Decreto 9331/78, coincidem com os estudos e a implantação do processo de microfilmagem dos documentos, anunciada pela administração como a grande solução para $\circ$ armazenamento dos documentos que se avolumavam. Acontece que a Lei 5433/68, em vigor, "autorizava em todo o território nacional a microfilmagem de documentos particulares e oficiais arquivados, estes de órgãos federais, estaduais e municipais" em seu artigo $1^{\circ}$. Mas ressalvava no artigo $2^{\circ}$, "Os documentos de valor histórico não deverão ser eliminados, podendo ser arquivados em local diverso da repartição detentora dos mesmos".

O último decreto elaborado pela administração tratando dos documentos públicos de arquivo do poder executivo municipal, de sua avaliação e destinação, e que ainda está é vigor, é o de $n^{\circ} 12.660 / 91$ que começa declarando sua conformidade com a Lei 5433/68, e inclui nos artigos $8^{\circ}, 9^{\circ}$ e $10^{\circ}$ as condições para microfilmagem e eliminação dos documentos.

Também em São Bernardo do Campo, a partir da determinação da microfilmagem dos processos constituiu-se uma comissão de avaliação, 
conforme a Portaria 6.844/89, "para realizar estudos quanto a eliminação de processos administrativos microfilmados."

Em Diadema, ainda que o processo de microfilmagem tenha sido breve e incipiente, também é o interesse em se implantar o Sistema de Microfilmagem que determina a formação de uma comissão de avaliação nomeada pelo prefeito em 1980, atendendo ao ofício do Diretor de Administração, no dia 10 de dezembro de $1979^{97}$,

"A fim de agilizar e racionalizar os Serviços de Microfilmagem de documentos do Arquivo Morto (...) cumpre-nos sugerir a V.Sa. a instalação de uma comissão especial (...) com o objetivo de se julgar os papéis considerados documentos para os fins de microfilmagem."

Aqui é importante lembrar que a lei que regula a microfilmagem de documentos públicos produzidos pelos poderes executivo, legislativo e judiciário, da União, dos Estados, Municípios e Distrito Federal, foi regulamentada pelo Decreto 1799/99, portanto após a promulgação da Lei 8.159/91 e adequa-se a ela, prevendo:

Artigo 12 - A eliminação de documentos após a microfilmagem, darse-á por meios que garantam sua inutilização sendo a mesma precedida de lavratura de termo próprio e após a revisão e a extração de filme cópia.

Parágrafo único - A eliminação de documentos oficiais ou públicos só deverá ocorrer se a mesma estiver prevista na tabela de temporalidade do órgão, aprovada pela autoridade competente na esfera de atuação do mesmo e respeitado o disposto no artigo $9^{\circ}$ da Lei $n^{\circ} 8.159$, de 08 de janeiro de 1991.

Artigo 13 - Os documentos oficiais ou públicos, com valor de guarda permanente, não poderão ser eliminados após a microfilmagem, devendo ser

\footnotetext{
${ }^{97}$ Processo Administrativo Interno 2.438/79, implantanção de Microfilmagem na Prefeitura Municipal de Diadema.
} 
recolhidos ao arquivo público de sua esfera de atuação ou preservados pelo próprio órgão detentor.

E o artigo $9^{\circ}$ da Lei 8.159/91, estabelece que para eliminação de documentos produzidos pelas instituições públicas, é necessária a "autorização da instituição arquivística pública, na sua específica esfera de competência". Ora, esta instituição como já demonstrado neste trabalho é na esfera do município, o "Arquivo Público Municipal”.

A legislação que continua em vigor nos municípios estudados ignora os novos dispositivos legais aos quais deveria se adequar. Mesmo aqueles que tentaram estabelecer Tabelas de Temporalidade de seus documentos durante algum tempo, deixaram esta tarefa. Assim, não existem Tabelas de Temporalidade para todas as Secretarias e as que existem não foram revistas e atualizadas, bem como os dispositivos legais que determinaram a criação das comissões de avaliação.

Pode ser válido utilizar a microfilmagem de substituição para documentos que devem ser custodiados por longo período de tempo por seus efeitos probatórios fiscais, administrativos ou legais, e que posteriormente serão destruídos, objetivando neste caso liberar espaço para armazenamento. Entretanto, ela é um ônus desnecessário para os que necessitam ser guardados por um período mais curto, antes de sua fragmentação.

Quanto aos que devem ser conservados, por espelharem as funções principais da administração e suas relações com os cidadãos, o destino dos originais deve ser o Arquivo Público Municipal, onde todos os interessados possam ter acesso a eles, administração, pesquisadores de todas as áreas, cidadãos. Neste caso, se compreende a microfilmagem chamada de preservação para garantir sua integridade e mesmo para servir de plataforma para a digitalização, como defendem os especialistas no assunto, facilitando o acesso. 
Já a avaliação, deve partir de uma fundamentação teórica que a justifique e aplicar as metodologias que garantam seja realizada com a eficiência e eficácia necessárias. A observância dos princípios arquivísticos e a legislação brasileira a respeito (Lei n 8.159/91, "Lei de Arquivos" e resoluções do CONARQ-Conselho Nacional de Arquivos, que normatizam as ações com relação aos arquivos públicos) permitem que a avaliação documental deixe de ser orientada pelo empirismo e a assessoria de profissionais da área pode viabilizar sua realização. Vimos, por exemplo, que a Diretoria da Fazenda contratou uma empresa especializada para fazer o diagnóstico e o projeto de microfilmagem para a Prefeitura de São Caetano. Mas não se contratam arquivistas, não se busca assessoria junto a Associação de Arquivistas de São Paulo, ou o Arquivo do Estado de São Paulo, para realizar o processo de avaliação documental nos municípios.

Temos com o Sistema de Arquivos da Universidade de São PauloSAUSP, o Sistema de Arquivos do Estado de São Paulo-SAESP, o SIARQSistema de Arquivos da Universidade Estadual de Campinas, o Arquivo Público Municipal de São José dos Campos em parceria com o Forum Nacional de Dirigentes de Arquivos Municipais-FORUMDAM exemplos de avaliação científica, fundamentada nos princípios da arquivística, feita por profissionais desta área ou com sua assessoria.

A avaliação dos documentos públicos de arquivo assim como sua microfilmagem devem ser parte de uma política de gestão documental, que considere o conjunto da produção documental dos vários órgãos da administração, levando em conta que estes documentos constituem um meio de comunicação entre a administração e o cidadão, e entre seus vários setores, que esta documentação tem valor de prova das ações da administração e dos direitos do cidadão. É importante considerar ainda, que as ações das administrações passadas tem relação com as que hoje ocorrem, seja por sua continuidade, seja por sua ruptura, e que, partir da 
análise das mesmas pode ser valioso ponto de partida para o planejamento das políticas públicas, daí o interesse em sua conservação.

Finalmente, que estes documentos, por seu caráter informativo, registram também a história e a memória da instituição e como a administração municipal tem vínculos muito estreitos com a cidade e seus habitantes, são também preciosos para a construção da história e memória dos mesmos. Pois, como aponta Bellotto (2002),

"o arquivo, ou melhor, os documentos de arquivo, quando na fase permanente, cumpridas as razões pelas quais foram criados, têm valor de informação e testemunho histórico, constituem a "consciência histórica" da administração e da sociedade em geral."

No mito grego, por toda a eternidade, Sísifo foi condenado a rolar uma grande pedra de mármore com suas mãos até o cume de uma montanha, sendo que toda vez que ele estava quase alcançando o topo, a pedra rolava novamente montanha abaixo até o ponto de partida por meio de uma força irresistível.

A análise dos documentos e o depoimento dos envolvidos nas experiências de avaliação documental realizadas por estas administrações, mostram as dificuldades encontradas para a constituição das comissões e o desenrolar de seus trabalhos, como a grande pedra de mármore, que com suas mãos Sísifo se esforçava em rolar até o cume de uma montanha. A cada quatro anos, com as eleições de novos governantes, ou a substituição de secretários e chefias, todos estes esforços e o trabalho realizado é abandonado e esquecido, repetindo o mito de Sísifo: "toda a vez que ele estava quase alcançando o topo, a pedra rolava novamente montanha abaixo, até o ponto de partida".

Também as atividades de microfilmagem têm um viés da tarefa de Sísifo, se considerarmos os esforços e recursos que os municípios 
estudados têm despendido e continuarão a dispender para a microfilmagem da maior parte dos processos e outros documentos produzidos, devido a inexistência de instrumentos de controle como Quadros de Classificação e Tabelas de Temporalidade atualizadas.

Apenas quando estas atividades deixarem de ser realizadas de forma compartimentada, vistas como solução para o problema emergencial da falta de espaço, para se integrarem em um processo amplo de gestão documental que contemple as várias fases do documento, da sua produção a sua destinação final, "Sísifo ficará livre do castigo dos deuses e conseguirá afinal rolar a pedra do alto da montanha." 


\section{5 - Avaliação documental: a teoria arquivística}

No ítem anterior, nos detivemos na descrição e análise de processos pragmáticos de avaliação de documentos das administrações estudadas, nosso objetivo agora é tratar a avaliação documental como uma função arquivística.

\section{1 - Conceituação}

O primeiro passo para o entendimento de um objeto de estudo é, em geral, conceituá-lo. Partindo da expressão "avaliação", como um vocábulo da língua portuguesa, encontramos no Dicionário Houaiss (2004),

"Avaliação: ato ou efeito de avaliar (-se). 1. cálculo do valor de um bem ou de bens. 2. por extensão, valor determinado por quem avalia. 3 . apreciação ou conjectura sobre condições, extensão, intensidade, qualidade, etc. de algo."

Ainda que os elementos "valor" e "critérios" também façam parte explícita ou implicitamente dos conceitos arquivísticos, quando se trata da avaliação documental, há especifidades que devem ser observadas, considerando o objeto da avaliação e os princípios da Arquivística.

Segundo o Conselho Internacional de Arquivos (1988), "Avaliação é a função arquivística fundamental determinante do destino dos documentos à partir de seu valor administrativo, fiscal, legal, probatório, de informação e de pesquisa, presente e futuro".

Os elementos "destinação" e "valores" também estão presentes na definição do Dicionário de Terminologia Arquivística (Camargo e Belloto, 1996), mas esta coloca em relevo a questão da "análise", esclarecendo que, "Avaliação é o processo de análise de arquivos, visando a estabelecer sua destinação de acordo com os valores que lhes foram atribuídos". 
Outros conceitos de avaliação podem ser encontrados e de acordo com a abordagem proposta, dão mais ênfase à seleção ou à conservação dos documentos, ao papel do arquivista, consideram o objeto da avaliação, ou ainda, o momento de realizá-la. Um fator significativo para modificar ou ampliar o conceito de avaliação arquivística, foi o aparecimento dos documentos eletrônicos, determinando a retomada ou o fortalecimento da preocupação com a autenticidade dos documentos.

A maior parte dos conceitos correntes coloca a avaliação em determinado momento do ciclo de vida dos documentos ou arquivos. Recentemente, o Arquivo Nacional da Austrália (2000) em um sentido mais amplo, parte da criação do documento, considerando a avaliação como um processo de análise das atividades de uma organização para identificar a necessidade de produção de documentos e quanto tempo devem ser conservados para atender os interesses da organização, a necessidade de transparência e as expectativas da comunidade. O conceito australiano também inclui entre os objetivos da avaliação, dois novos elementos: leva em consideração a necessidade de informação sobre as atividades do governo e os interesses da comunidade.

Também é importante apontar o uso do vocábulo "seleção", como sinônimo de "avaliação", ainda que esclareçam Machado e Camargo (1999), "Seleção é a eleição, durante o processo de avaliação, dos documentos de valor permanente e daqueles passíveis de eliminação, com base em critérios técnicos previamente estabelecidos".

Apesar da necessidade e da procura de normalização terminológica, isto também ocorre, com maior freqüencia nos países de língua inglesa, com as expressões "appraisal" e "selection", entre os franceses, com "évaluation", "sélection" e "tri" (de "triage") ou "tri sélectif", e ainda entre os países de língua espanhola, com "evaluación", "valoración" e "selección". Estas expressões são utilizadas muitas vezes indistintamente, como sinônimas. 
Do início do século passado aos nossos dias, concordam os teóricos de diferentes países sobre a centralidade da avaliação entre os processos arquivísticos e os dilemas e dificuldades que impõe, por isso Schellenberg (2002) fez referência aos "traiçoeiros caminhos da avaliação" e Belloto (1990), afirmou, "é a área de maior desafio profissional para o arquivista".

Mas é indiscutível sua crescente valorização entre os teóricos da arquivística, expressa por Couture (2001),

“(...) não há nenhuma originalidade em afirmar que a função avaliação constitui o núcleo duro da disciplina arquivística. Um grande número de autores o proclamou muito bem antes de nós. Mas nós devemos repetílo com força e convicção. A avaliação é uma das especificidades mais marcantes da arquivística contemporânea, já que ela tem por objeto decidir sobre o material (documento-continente e informação-conteúdo) sobre o qual vão recair todas as intervenções do arquivista. A criação, a aquisição, a classificação, a descrição, a difusão e a conservação dos arquivos são todas devedoras das decisões tomadas quando da avaliação destes últimos."

O crescimento da produção documental e a consciência de que não se pode conservar tudo, complexidade e reestruturações freqüentes nas administrações e a utilização crescente dos documentos eletrônicos, têm provocado a necessidade de se ampliar os estudos sobre esta atividade arquivística, daí as novas abordagens e teorias. Estas também são resultado da preocupação em vincular a questão dos documentos de arquivo aos interesses da sociedade e à "accountability", transparência, prestação de contas. E ainda, da consciência que a necessidade da avaliação de documentos de certa forma transforma esta função como afirma Terry Cook (1999) em "criadora de arquivos", decidindo o que é lembrado e o que é esquecido, quem na sociedade é visível e quem permanecerá invisível, quem tem voz e quem não a tem. 


\section{2 - A avaliação como função arquivística - um breve histórico}

Se a função de arquivar remonta a antiguidade, o mesmo não ocorre quando se trata da avaliação arquivística, conforme Eastwood (2001)

"Em um sentido qualquer, toda sociedade geradora de documentos tem de alguma forma ou outra, consciente ou inadvertidamente, determinado a destinação de seus arquivos. Entretanto, considerar a avaliação como um processo consciente ligado a aquisição de materiais por um programa ou instituição arquivística, é um fenômeno relativamente recente, em grande parte porque as instituições arquivísticas da espécie que temos hoje, apareceram na Europa somente cerca de dois séculos atrás."

Os estudos de Kalenski ${ }^{98}$ (apud VÁZQUEZ, 2002) e Kolsrud (apud COUTURE, 1997) buscam recuperar as primeiras iniciativas de avaliação de documentos. Um primeiro período na história da seleção dos documentos seria anterior a 1880, quando a seleção era realizada por funcionários ou empregados da administração oficial, sem consultar nem arquivistas nem historiadores $^{99}$. Neste primeiro período, já em 1832, Francisco I da Áustria teria promulgado os primeiros regulamentos para a eliminação e destruição de séries inúteis em arquivos e registros, pois a burocracia de seu império produzia e arquivava muitos papéis. Estes regulamentos mencionavam o interesse histórico que podia existir em documentos pouco úteis para a administração. Em 1833, um regulamento semelhante foi estabelecido na

\footnotetext{
${ }^{98}$ Historiador e arquivista polonês, em 1934 recomendava a elaboração de tabelas, como técnica de destinação de documentos, escreveu um ensaio sobre os valores dos documentos, para a continuidade do governo e a pesquisa erudita (SOARES, 1998).

No início do século XIX a eliminação de documentos esteve ligada a raridade do papel na época. A eliminação era feita para reutilizar o papel com fins militares, reciclado, era usado para a fabricação de cartuchos. Este tipo de critério parece ter desaparecido na metade do século XIX (DELSALLE, 1998).
} 
Prússia, mas os critérios mencionados eram todos de interesse administrativo. Citando Kolsrud, Couture afirma que desde esta data o governo prussiano adotava meios para julgar o valor dos documentos gerados por suas atividades. Assim, em 1858, não se pôde mais na administração governamental prussiana, eliminar documentos sem informar as autoridades arquivísticas.

Quanto à Rússia, são mencionados dois decretos, de 1830 e 1845 , sendo o principal motivo para a destruição de documentos a falta de espaço, assim como para outros decretos que aparecem entre 1860 e 1864.

Nesta época, entre 1835 e 1844, aparecem na Inglaterra leis e regulamentos determinando a eliminação de documentos sem valor e na França regulamentos que introduzem pela primeira vez naquele país, a noção de preservação para fins de pesquisa histórica (EASTWOOD, 2001).

No segundo período, conforme Kalenski, a partir de 1880, as regulamentações vão ficando mais detalhadas. Os funcionários recebiam parte dos ganhos com a venda do resíduo e os historiadores e arquivistas intervinham para salvar os valores históricos.

A partir do fim da Primeira Guerra, temos o terceiro período da seleção a partir das revoluções em vários países - Rússia, Alemanha, Áustria e Polônia - que favorecem a centralização dos arquivos de Estado retirando os documentos dispersos dos ministérios. Kalenski afirma que nesta oportunidade os arquivistas entraram em contato, às vezes pela primeira vez, com documentos administrativos contemporâneos, e que nesta fase, passam a aprovar a seleção.

Verificam-se então duas grandes tendências segundo os estudiosos: na Alemanha, a avaliação para conservação, e na Inglaterra, a avaliação para eliminação.

As atividades de avaliação na Inglaterra, visando a eliminação, se desenvolvem a partir de 1875 (KOLSRUD, apud COUTURE, 1997) quando o Diretor ("deputy keeper") passa a ter o poder de eliminar os documentos que 
segundo ele, não teriam mais utilidade. Este poder foi confirmado pelo Public Record Office Act, em 1877, que excluía da avaliação documentos anteriores à 1715. Em 1954 esta data foi substituída por 1660.

Os procedimentos arquivísticos na Inglaterra foram particularmente influenciados por Sir Hilary Jenkinson. Seu Manual de Administração de Arquivos, publicado em 1922, defendia que apenas a organização produtora poderia avaliar e destruir seus documentos, levando em conta seus próprios critérios e valores. Nenhuma outra pessoa poderia intervir, porque arquivistas, pesquisadores ou historiadores correriam o risco de impor suas visões pessoais e assim alterar o processo natural de seleção da massa documental. Era a defesa extrema da objetividade buscando a eliminação de qualquer subjetividade. Assim, os critérios de eliminação seriam apenas de ordem administrativa. Como resultado destas teorias, na Inglaterra as administrações passam a gozar de grande autonomia para dispor de seus arquivos e em decorrência, as taxas de conservação são baixas.

Avaliar para eliminação tem sido uma prática adotada por muito tempo e em muitas administrações pelos fatores apontados: economia de espaço e de despesas com o armazenamento, liberação de recursos humanos e materiais. Mas, aqui uma contradição é apontada por Kromnov (1981), se por um lado os responsáveis pelos arquivos sofrem grande pressão por parte dos governos para intensificar as eliminações, com vistas aos benefícios financeiros que proporcionam, por outro lado, surpreendentemente muitos países liberam uma porcentagem relativamente pequena de pessoal para as operações de avaliação e descarte.

Contrapondo-se aos princípios defendidos por Hilary Jenkinson e ao que poderíamos chamar de corrente inglesa, temos a "avaliação para conservação" defendida pelos alemães. A preocupação em racionalizar as atividades administrativas fez com que a Alemanha fosse um dos primeiros países a se preocupar com a avaliação dos documentos, como vimos 
anteriormente. Quanto a orientação adotada, já em 1926, Karl Otto Müller defendeu a necessidade de negar às administrações o direito de serem os únicos juízes em matéria de seleção documental, pois os arquivistas deveriam ter uma influência decisiva na avaliação (KOLSRUD apud SILVA, 1999). As idéias defendidas por Müller (1926) e posteriormente por Meisner (1937) e Zimmerman (1958) são contribuições significativas dos alemães para as discussões que se colocam sobre a questão da avaliação.

Müller, segundo Couture (1997), propõe uma primeira abordagem em que a avaliação deveria se apoiar sobre o nível no qual se situa o "organismo criador dos documentos". Para ele existiriam três níveis de administração: o central e o intermediário produziriam arquivos que apresentam maior valor que os que se situam no nível local, estes arquivos teriam menor interesse.

Heinrich Otto Meisner propõe três princípios básicos que deveriam ser considerados para a avaliação dos arquivos: a idade dos documentos, seu conteúdo e a posição hierárquica do organismo criador. Considerando os níveis de administração previstos por Müller, Meisner acrescenta quanto a categoria intermediária que os documentos deveriam ser julgados segundo o grau de autonomia do organismo criador concernente.

Já Fritz W. Zimmerman (1958), defende uma abordagem que leva em consideração mais a utilização do documento (demanda) que sua origem, valorizando o conteúdo do documento e sua utilização. Para ele é a pertinência e não a proveniência relacionada organicamente que constitui o valor real dos documentos (KOLSRUD apud COUTURE, 1997).

A avaliação apoiada em uma escala de valores marxistas foi defendida em 1969 por Joachim Schreckenbach (arquivista da Alemanha Oriental). Para ele somente um contexto socialista pode permitir uma percepção interessante em matéria de avaliação. Assim, por exemplo, apesar de aceitar como princípio a posição hierárquica do organismo criador defendida pelos alemães ocidentais, tanto a Alemanha Oriental, como a 
União Soviética e a Bulgária, acrescentaram a este, uma "teoria marxistaleninista de valor, os documentos eram avaliados de acordo com a importância que tinham para a sociedade socialista, no seu objetivo primordial de levar a cabo a missão histórica de classe operária. A avaliação regia-se por uma definição oficial do conceito de valor" (KOLSRUD apud SILVA, 1999).

Esta teoria de avaliação será discutida por outro arquivista da Alemanha Ocidental, Hans Booms. Couture relata que em 1972, Booms publica um texto "mestre" sobre a avaliação, "Os sistemas socialistas e a seleção de documentos; a avaliação de arquivos". Booms afirma que até 1972, os arquivistas (do ocidente e do leste) não teriam conseguido uma solução conjunta para a avaliação. Ele não aceita nem as idéias de Müller, Meisner, e Zimmermann, nem as dos países socialistas, afirmando que o arquivista deve se preocupar com os interesses do conjunto da sociedade em matéria de avaliação de arquivos.

Traduzido e publicado na revista Archivaria em 1987, suas idéias terão um importante impacto no Canadá inglês e nos EE.UU. a partir do próprio título de seu texto, "Sociedade e a formação de uma herança documentária: resultados da avaliação de fontes arquivísticas". No processo de avaliação, para Booms, o arquivista deve considerar a sociedade no sentido amplo, a constituição do patrimônio social, e papel do arquivista na constituição e na gestão deste patrimônio.

Os arquivistas americanos adotam à princípio a abordagem inglesa, vendo na avaliação um meio para eliminar documentos. Posteriormente passam a ser defendidos critérios para a avaliação e uma abordagem que leva a preservação dos documentos. Sucessivamente temos arquivistas americanos preocupados em estabelecer critérios para a avaliação. Já em 1940, Philip Brooks propõe a eliminação das cópias e a importância de se definir o que é o valor permanente. Segundo Brooks três critérios deveriam ser levados em consideração quanto ao valor permanente dos documentos: 
o valor que a instituição de origem dá aos documentos, a utilidade que apresentam os documentos para a história administrativa da instituição e o valor histórico dos documentos.

A preocupação com o volume elevado de documentos que se verifica nesta época também levou a arquivista americana Margaret Cross Norton a defender, entre 1930 e 1944, que sendo impossível para qualquer instituição preservar todos os documentos produzidos como resultado de suas atividades a ênfase do trabalho arquivístico "mudou da preservação de documentos, para a seleção de documentos para preservação" (apud COOK, 1997).

Se ao contrário de Jenkinson, Norton defendia que a avaliação dos documentos era responsabilidade dos arquivistas e não da administração produtora dos documentos, concordava com ele que a principal tarefa da avaliação era eliminar documentos desnecessários e redundantes, para deixar uma memória documental efetiva e eficiente (...). Norton não considerava que os arquivos deviam servir aos interesses da pesquisa histórica preferencialmente, acreditando que o principal objetivo da avaliação era preservar os documentos de valor legal permanente que estabeleciam e protegiam os direitos e interesses do estado e seus cidadãos (EASTWOOD, 2001).

Já Philip Bauer (1946) propõe considerar o uso e os custos que implicam a aquisição e a conservação dos arquivos. Segundo Couture (1997), Bauer previa o uso dos arquivos para as instituições governamentais, para a proteção dos direitos dos cidadãos, para pesquisas "sérias", para satisfazer a curiosidade dos genealogistas ou eruditos. E propunha três critérios que permitiriam julgar sua utilidade:

- as características e a importância quantitativa da informação contida nos documentos

- a pertinência de sua classificação

- a densidade e a importância qualitativa do conteúdo. 
Entretanto ficaram mais conhecidos e tiveram maior influência, os critérios defendidos por Schellenberg para a avaliação dos documentos. Historiador e arquivista do Arquivo Nacional dos Estados Unidos desde 1935, Theodore R. Schellenberg, publicou no "Archives Bulletin", n 8, do National Archives, dos Estados Unidos, seus princípios e técnicas de avaliação. Posteriormente estes princípios foram incorporados a seu livro Arquivos Modernos: princípios e técnicas (Modern Archives: principles and techniques), editado nos Estados Unidos, em 1956. No prefácio da $1^{a}$ edição o autor esclarece que esta obra é resultado de uma série de conferências feitas na Austrália, em 1954, sobre o problema da administração de documentos públicos e que é, de certo modo, um estudo de contrastes entre os princípios e as técnicas desenvolvidas nos EUA em relação a novos sistemas de arquivamento e os desenvolvidos em outros países em relação ao sistema de registro.

Quanto a questão da avaliação, Schellenberg (2002) ${ }^{100}$ manifesta sua preocupação com o crescimento e o grande volume dos documentos oficiais modernos, com a impossibilidade e o custo para armazená-los e cuidar dos mesmos, com a necessidade de reduzí-los para que fossem úteis à pesquisa erudita. Schellenberg defende ainda "um cuidadoso trabalho de análise" e o "máximo cuidado para a conservação dos que têm valor".

Menne-Haritz (1994) afirma que, influenciado pelas teorias e práticas prussianas transferidas para os Estados Unidos pelo emigrante Ernst Posner, Schellenberg teria desenvolvido uma teoria que é, ainda hoje, a única que mais consequentemente aplica a premissa do livre princípio da proveniência na avaliação. E que percebendo que os documentos públicos são conservados na instituição arquivística porque eles têm valores que existirão mesmo depois que eles deixam de ter uso corrente e porque seu valor será

\footnotetext{
${ }^{100}$ A primeira edição brasileira de "Arquivos Modernos: princípios e técnicas" foi publicada em 1973, pela Fundação Getúlio Vargas, com tradução de Nilza Teixeira Soares A edição atual é de 2002, pela mesma editora. Anteriormente o Arquivo Nacional já havia publicado em 1959, "A avaliação de documentos públicos" (The Appraisal of Modern Public Record), com tradução de Lêda Boechat Rodrigues.
} 
outro além do uso corrente, Schellenberg formulou a base de sua abordagem teórica, que é a discriminação entre valor primário e secundário do documento de arquivo.

O valor primário do documento se refere a razão pelo qual o mesmo foi criado, respondendo a necessidades de ordem administrativa, legal ou financeira. Quanto aos valores secundários são os que o documento pode adquirir quando não é mais imediatamente útil a instituição que o criou. Nesse caso o documento pode ter valor probatório (evidencial values) e valor informativo (informational values).

Os valores probatórios são aqueles que contém fatos significativos sobre a criação da instituição, seu desenvolvimento, sua organização, suas funções e as conseqüências de suas atividades. Já os valores informacionais, referem-se não à prova das ações do governo contidas nos documentos oficiais, mas às informações que existem nos documentos públicos sobre pessoas, lugares, coisas, eventos, propriedades, que deram origem a ação competente.

Nos anos 70, com o arquivista americano Gerald Ham temos a discussão sobre a avaliação ligada a aquisição: questionando os resultados obtidos com a avaliação feita até o momento ${ }^{101}$, Ham acentua a importância de desenvolver políticas institucionais, regionais e nacionais de aquisição que ele vê como componentes essenciais da avaliação. Esta preocupação será ampliada nos anos 80 com a abordagem conhecida como "política de aquisição", que busca harmonizar os critérios de avaliação de um organismo com uma política institucional de aquisição de arquivos em conformidade com a missão, os valores, os mandatos, a cultura organizacional e as funções deste organismo.

Bernier (1995) lembra ainda que,

\footnotetext{
${ }^{101}$ Ham argumentava que os resultados eram "um processo de seleção sem método, tão fragmentado, tão descoordenado, e mesmo tão frequentemente acidental (...)" e ainda, "que as realizações arquivísticas refletiam mais frequentemente interesses limitados para a pesquisa que o mais amplo espectro da experiência humana" (Cook, 1999).
} 
"Certos arquivistas como Ann Pederson vão mais longe e preconizam uma abordagem resolutamente intervencionista que consistia na elaboração e aplicação de estratégias ativas de aquisição. Neste quadro, o arquivista interviria não somente sobre o conteúdo da informação que ele desejasse adquirir, mas também sobre o suporte físico sobre o qual seria consignada esta informação, no momento, ou mesmo antes da criação do documento, para recomendar um suporte em vez de outro, em uma ótica de conservação permanente.

Com Helen Samuels ${ }^{102}$, nos anos 80 , as idéias de Ham sobre avaliação e aquisição serão ampliadas, com a criação do conceito de estratégia de documentação: "os elementos chave nessa abordagem são uma análise do universo a ser documentado, um entendimento dos problemas inerentes aos documentos e a formulação de um plano para assegurar a documentação adequada para um tema que está sendo discutido ou para uma atividade ou sobre uma área geográfica" (SAMUELS, 1993).

Já em 1991, ainda na ótica do estabelecimento de critérios para avaliação, Frank Boles e Julia Marks Young publicam uma obra ${ }^{103} \mathrm{em}$ que procuram articular os critérios apontados até então. Confrontando uma possível teoria de avaliação com a realidade cotidiana de arquivistas que trabalhavam em quinze centros de arquivos diferentes, Boles e Young, dividiram os critérios estabelecidos em três módulos:

- 19 critérios ligados ao valor da informação

- 5 critérios ligados aos custos de conservação

- 6 critérios ligados às conseqüências da decisão resultante da avaliação.

\footnotetext{
${ }^{102}$ Em 1985, juntamente com Joan Haas e Barbara Simmons, Helen Samuels publica um estudo sobre a avaliação de arquivos do campo das ciências e tecnologia, "Appraising the records of Modern Science and Technologie: A Guide", distribuido pela Society of American Archivists.

${ }^{103}$ Frank Boles e Julia Marks Young, Archival Appraisal, New York, Neal Schuman, 1991.
} 
A década de 80 trouxe também a crescente utilização dos documentos eletrônicos nas instituições públicas, determinando novos questionamentos e abordagens quanto a gestão e portanto, a avaliação dos documentos. Como afirmou Turner ( apud FERNÁNDEZ, 2002)

"esta intrusão dos documentos eletrônicos, em nosso confortável mundo de transações em papel, forçou o reestabelecimento de nossas concepções sobre a avaliação que redundou em uma renovada versão da coerência proposta por Hilary Jenkinson, através da noção de imparcialidade do documentos, que reconhece que a natureza imparcial, autêntica e confiável dos arquivos deriva do processo de sua criação e da acumulação natural dos documentos, que por isso mesmo deve ser conservada".

Buscando melhor entendimento dos documentos da burocracia moderna, a professora Luciana Duranti (da Universidade de British Columbia), desenvolveu um estudo profundo da Diplomática, gerando o que ela mesmo chama de "diplomática arquivística contemporânea", fundamental para o processo da avaliação dos documentos eletrônicos. Isto porque, como lembra Menne-Haritz $(1944)^{104}$, "Hoje os sistemas eletrônicos nos permitem ver mais claramente (...) o medo de ser soterrado por grandes massas de papel foi substituído agora pela consciência que nada será deixado para avaliação se nós não formularmos princípios de avaliação que guiarão nossas decisões diárias."

Também a partir da década de 80 , no Canadá, na Holanda e na Austrália temos a chamada abordagem social ("societal approach") e o que poderíamos chamar de método funcional de avaliação. Na verdade, as idéias defendidas pelos teóricos destes países e suas metodologias de avaliação,

\footnotetext{
${ }^{104}$ Traduzimos.
} 
resultam de idéias e teorias criadas anteriormente, que passam a ser gradativamente desenvolvidas pelos teóricos e arquivistas destes países.

Com Terry Cook, dos Archives Nacionales du Canada-ANC, Terry Eastwood e Luciana Duranti da University of British Columbia-UBC e outros teóricos e arquivistas canadenses temos as tendências que Couture (1996), sintetiza como:

- as do ANC, a macro-avaliação, orientada pela avaliação da instituição (contexto de criação) que deve necessáriamente preceder a dos documentos (from the top to the bottom);

- a que propõe que a utilização dos arquivos seja uma condição primordial para sua avaliação;

- a de Quebec que insiste sobre o caráter essencial do calendário de conservação, íntima e obrigatoriamente ligado a análise de necessidades.

Além de analisar a estrutura, as funções e atividades das instituições governamentais em sua interação com as pessoas e organizações da sociedade, as abordagens nestes países também se caracterizam pelo que Cook (1997) chama de "redescoberta da proveniência" (rediscovery of provenance).

Analisando a literatura sobre avaliação, Luciana Duranti (1994) afirma que, "é fácil identificar imparcialidade e objetividade como a contribuição da Inglaterra, profissionalismo e análise como contribuição americana e perfeição (integralidade) de resultados (efeitos), como contribuição alemã."

Quanto à contribuição canadense, Couture (1996) afirma que "em matéria de avaliação de arquivos [ ela ] é de síntese e de nuance. Ela se inspira principalmente em posições definidas por europeus e americanos, reconhecendo aí as considerações ligadas à instituição criadora dos documentos, à utilização dos arquivos, ao valor que apresentam os arquivos e à preocupação mais ampla de querer testemunhar o conjunto da sociedade." 


\section{3 - Avaliação: principais abordagens teóricas e metodológicas}

O ítem anterior procurou traçar em linhas gerais, um histórico da avaliação arquivística, de maneira a permitir uma visão panorâmica da mesma do século XIX, até o presente. Nossa intenção agora é tratar suas principais abordagens teórico-metodológicas, mas considerando a complexidade do assunto e os dilemas que suscita, lembramos como Craig (2004)

"A avaliação é menos um itinerário para uma viagem e mais um mapa de conceitos para nosso uso no planejamento de muitas viagens. A complexidade inerente da avaliação sugere cuidado quando tentamos fazer declarações absolutas".

Em seu conhecido e polêmico artigo sobre avaliação, publicado na revista American Archivist, Duranti (1994), estabelece uma distinção entre teoria, metodologia e prática arquivística,

\footnotetext{
"Teoria arquivística é o conjunto de idéias sobre o que é a matéria prima (substância) arquivística, enquanto que metodologia arquivística é o conjunto de idéias sobre como tratá-la e a prática arquivística, o uso que os arquivistas fazem de ambas, idéias teóricas e metodológicas em seu trabalho".
}

No mesmo artigo afirma que maior parte da teoria sobre avaliação é resultado da sistematização de normas pragmáticas sobre a prática mais conveniente e/ou politicamente correta, mas que este processo precisaria ser revertido: "A teoria deve determinar o método, e o método deve guiar a prática." 
A necessidade de partir de uma fundamentação teórica clara, e que deve ser explicitada quando são tomadas as decisões do que deve ser conservado e do que deve ser eliminado no processo da avaliação, tem sido apontada hoje com frequência pelos estudiosos do assunto.

Sobre a importância da teoria e do método, e as relações entre eles, Craig (2004) afirma,

\begin{abstract}
"A teoria que é clara e articulada é a mais forte fundamentação para os métodos. Métodos são procedimentos ao contrário da natureza especulativa e abstrata da teoria. Métodos 'operacionalizam' tarefas e mostram os trabalhos que devem ser feitos. Para ser efetivo, um método deveria ligar uma teoria a uma situação concreta - um método não é um fim em si mesmo. Uma razão para o desenvolvimento de vários tipos de método é que cada um expressa um entendimento teórico particular do propósito da avaliação e seu objetivo na economia do arquivo".
\end{abstract}

O crescimento da produção dos documentos colocou em evidência a avaliação documental gerando novas teorias e metodologias, a partir dos anos 70, sobretudo nos Estados Unidos e Canadá, mas também em outros países. A partir daí um debate intenso tem se travado, contrapondo as principais controvérsias e dicotomias. Sem a pretensão de esgotar o assunto trataremos de suas linhas mestras à seguir.

A abordagem tradicionalista, também é chamada Escola Européia. Influenciada pelas leis romanas, e conceitos como "fé pública" e "memória perpétua"105, suas idéias tornaram-se a base do pensamento europeu sobre arquivos, que se caracterizam pela defesa dos princípios de imparcialidade, autenticidade, naturalidade, inter-relação e unicidade dos documentos

\footnotetext{
${ }^{105}$ Segundo a autora "como a lei Romana tornou-se a lei civil comum na Europa e a base de sua unidade espiritual e cultural, estes conceitos tornaram-se os fundamentos de todo o pensamento europeu sobre arquivos". Traduzimos.
} 
(DURANTI,1994). No nível metodológico, esta abordagem se fundamenta nos princípios da proveniência e da ordem original dos documentos.

O arquivista inglês Hilary Jenkinson, um dos expoentes desta Escola, estabelece que o arquivista não deve intervir no arquivo, mas ser apenas seu guardião, preservando suas características. Segundo ele, avaliar para decidir que documentos deveriam ser conservados conflita com a mais importante responsabilidade do arquivista, que é a defesa física, intelectual e moral dos documentos. Portanto, Jenkinson defendia a objetividade no tratamento dos arquivos, cabendo ao responsável pela produção dos documentos, ou administrador, na expressão de Jenkinson, realizar a seleção que fosse necessária no âmbito administrativo-jurídico.

Esta posição explica-se segundo Cook (1997), pelo fato de Jenkinson ter trabalhado no Public Record Office de Londres, em 1906, quase exclusivamente com documentos medievais e do novo estado nacional. Daí sua insistência no caráter legal dos documentos de arquivo, sua natureza probatória, a sua estabilidade e integridade inerentes. Sua preocupação com a verdade do documento de arquivo, estaria ligada ao positivismo comum à historiografia que Ihe era familiar.

Suas idéias são criticadas por arquivistas como Gerald Ham (apud COOK, 1997), segundo o qual Jenkinson, "Permitindo que o produtor determine o que será documento de arquivo, resolve os problemas de complexidade, volatilidade e volume dos documentos contemporâneos, ignorando-os." Seria uma forma utilizada por ele para resolver os dilemas da avaliação.

E Cook (1997), transpondo as idéias jenkinsonianas para os dias de hoje, afirma que seguir sua orientação, seria sancionar que produtores de documentos como o presidente Richard Nixon e George Bush destruam ou escondam documentos do julgamento público, contendo provas desfavoráveis de suas ações, prejudicando ambos, a transparência democrática e o conhecimento histórico. Ou, em casos extremos, o legado 
arquivístico poderia ser pervertido por caprichos administrativos ou pela ideologia do Estado. Mas admite que as idéias de Jenkinson sobre o caráter probatório dos documentos têm influenciado arquivistas de todas as partes do mundo.

Os princípios defendidos por Jenkinson têm subsidiado teóricos atuais sobretudo a partir da proliferação dos documentos eletrônicos, que coloca para o arquivista novas questões, sobretudo com relação à autenticidade dos documentos. É o caso de Luciana Duranti, que contrapõe às teorias de avaliação documental baseadas na atribuição de valores aos mesmos, os princípios da teoria arquivística que caracterizam $\mathrm{o}$ arquivo e seus documentos,

"a atribuição de valores para documentos de arquivo estaria em conflito com todos eles, já que a naturalidade e a inter-relação apontam para o fato de que todos o documentos em um arquivo têm igualmente uma função que justifica sua existência com relação ao conjunto deles. Por outro lado as características de imparcialidade e autenticidade apontam para a qualidade probatória de forma e procedimento e ainda para sua primazia no estabelecimento da verdade. Mais ainda, a característica de unicidade no contexto de cada documento, torna seu significado único e sua existência necessária para o significado do arquivo ao qual ele pertence" (1994). ${ }^{106}$

Assim, atribuir valores aos diferentes documentos de arquivo, e destruir os de menor valor, provocaria a perda da integridade deste arquivo, alterando o significado do conjunto e de suas partes.

Também para a mesma autora, "Atribuir valor para a evidência [do passado] poderia significar a renúncia à imparcialidade, endossar a ideologia, e consciente e arbitrariamente alterar o registro da sociedade".

\footnotetext{
${ }^{106}$ Traduzimos
} 
Estas considerações de Luciana Duranti, provocaram polêmicas, como as levantadas pelo arquivista Adrian Cunningham, e foram respondidas por ela em uma carta ${ }^{107}$ esclarecendo não ter afirmado que,

\begin{abstract}
"na teoria e prática arquivísticas não haveria lugar para avaliação, mas sim que o conceito de valor contraria o de documento, que o tratamento dos documentos está condicionado pelo sistema jurídico administrativo no qual eles são gerados e/ou utilizados, e este dá lugar a seleção no contexto moderno. Da mesma forma, a metodologia para seleção também deve estar baseada no contexto jurídico-administrativo dos documentos, em oposição aos caprichos da pesquisa histórica ou da estratégia de documentação." 108
\end{abstract}

As idéias defendidas pela Escola Européia e por Luciana Duranti são opostas às da Escola Americana, que tem seu mais influente teórico em Theodore R. Schellenberg. Ainda que outros autores tenham, antes e depois dele, defendido a avaliação dos documentos através do estabelecimento de valores para os mesmos, as idéias de Schellenberg tiveram maior penetração e ainda hoje constituem fundamentos para muitas metodologias de avaliação. Sobre seus escritos, Eastwood (2001) afirma que talvez nenhum outro documento sobre avaliação tenha sido tão influente, pelo menos entre os países de língua inglesa, ou tenha sido tão mal interpretado.

Schellenberg (2002), partiu da constatação que havia documentos que eram preservados em arquivos porque tinham valores que persistiam por muito tempo, ainda depois de cessado seu uso corrente e que seriam de interesse para outros, que não os usuários iniciais. Portanto, fundamentou sua abordagem teórica na distinção entre valores primários e secundários. Os valores primários nasceriam do cumprimento dos objetivos para os quais

\footnotetext{
${ }_{107}^{107}$ Cunningham`s commentary, 1997.

${ }^{108}$ Traduzimos.
} 
um órgão foi criado - administrativos, fiscais, legais e executivos - e seriam prioritários.

Quanto aos valores secundários dos documentos, Schellenberg considerava dois aspectos:

- o valor de prova que estes possuem da organização e do funcionamento do órgão governamental que os produziu, que Schellenberg chamou de "evidencial values" ou valores probatórios.

- a informação que possuem sobre as pessoas, entidades, coisas, problemas, condições, etc., com que o órgão governamental tenha se relacionado, constituindo os valores informativos, "informational values".

Schellenberg esclarecia que para ele o valor de prova dos documentos não tinha o mesmo sentido que o atribuído por Hilary Jenkinson, a santidade da prova dos arquivos que deriva de sua "custódia ininterrupta". Mas que se referia ao valor que depende do caráter e da importância da matéria provada, isto é, da origem e dos programas substantivos, ou da entidade que produziu o documento. $E$ ainda, que esta distinção entre valor de prova e valor informativo é apenas para efeito de estudo e que os dois tipos de valores não se excluem mutuamente.

Uma série de testes criados por Schellenberg orientariam os arquivistas na avaliação dos valores informativos (quanto a sua unicidade, forma e importância) e probatórios (neste caso deve-se levar em consideração a origem, o desenvolvimento e o funcionamento da instituição).

Analisando os critérios estabelecidos por Schellenberg, Couture (1998) vê o conceito de testemunho ou prova (evidential value) ligado à estrutura, à função e às atividades próprias à cada unidade de um dado órgão. Trata-se então da história da instituição. Já o conceito de informação (informational value), segundo ele, compreende uma dimensão extrainstitucional e aproxima-se de Hans Booms que pretendia que a avaliação permitisse testemunhar as atividades do conjunto da sociedade. 
Duranti (1994) critica o que chama de "pragmatismo" em Schellenberg, sua não observância das características dos documentos conforme a tradição arquivística e uma abordagem da avaliação voltada para o interesse dos pesquisadores. Já Menne-Haritz (1994), considera que Schellenberg foi mal interpretado quanto ao estabelecimento dos valores probatórios e que este foi influenciado pelo princípio da livre proveniência de Brennecke.

Outra crítica feita a Schellenberg e a outros arquivistas da chamada Escola Americana, refere-se ao fato de considerarem "arquivos" apenas aquela parcela de documentos escolhidos pelos arquivistas para preservação por longo tempo ou permanentemente. Enquanto que a expressão "records" é utilizada para os documentos nas fases anteriores, administrados pelos "records managers".

Buscando contextualizar as idéias de Schellenberg, Cook (1997) afirmou que estas refletiam a política cultural e estatal americana do New Deal, com ênfase nos benefícios de uma administração tecnocrática e eficiente. E Craig (2004) considera que,

"Buscando uma visão mais ampla dos arquivos e novas abordagens, o Arquivo Nacional dos Estados Unidos e Schellenberg estavam interessados também em um papel independente para sua instituição e viam na avaliação o meio pelo qual os Arquivos poderiam estabelecer sua credibilidade como um útil departamento do governo. Suas idéias se ajustavam aos interesses do governo por eficiência através de métodos científicos de organização. Sua visão também sublinhava o papel dos Arquivos como uma instituição de pesquisa, servindo uma elite acadêmica de historiadores, que necessitavam dos arquivos para pesquisa. Schellenberg viu a avaliação como um meio para os Arquivos estabelecerem sua bona fides, na administração e pesquisa". ${ }^{109}$

${ }^{109}$ Traduzimos. 
Surgem outras concepções teóricas e metodológicas, sobretudo na Alemanha, nos Estados Unidos e no Canadá, são os modelos social (societário) $)^{110}$ e funcional e a macro-avaliação.

A partir dos anos 70, arquivistas como Gerald Ham questionam o discurso arquivístico baseado no Estado, buscando refletir de forma mais ampla a sociedade que é servida por ele. Considerando que as grandes burocracias governamentais e as grandes empresas, eram apenas uma parte da sociedade, e a que tem mais poder, viam como dever dos arquivos documentar a experiência de outros grupos não privilegiados enfatizando seu papel social.

Outra abordagem teórica dentro deste enfoque foi elaborada por Helen Samuels, que desenvolveu o conceito de estratégia de documentação, descrita em seu livro, Varsity Letters, um estudo funcional de colégios e universidades norte-americanos, como o primeiro passo para desenvolver projetos com o objetivo de documentar instituições. A estratégia de documentação integra em sua análise, documentos de órgãos oficiais e de outras instituições com documentos pessoais, audiovisuais, informações publicadas em outros meios e mesmo história oral.

Também caracteriza esta abordagem o fato de ser multi-institucional, podendo envolver ao lado de arquivos, bibliotecas, institutos de pesquisa, centros de documentação. Contrariando os princípios arquivísticos tradicionais, Samuels (apud LYBECK, 2004) prevê que caso a documentação tenha desaparecido ou seja escassa, o arquivista deve desempenhar um papel ativo, criando ele mesmo esta documentação ou incentivando grupos influentes a fazê-lo. Entretanto a estratégia da documentação não rejeita a versão renovada do princípio da proveniência e a análise funcional dos produtores de documentos.

\footnotetext{
110 Não encontramos uma tradução exata para "Societal Approach" e a expressão ainda não consta do Dicionário de Terminologia Arquivística disponível.
} 
Sobre o conceito norte-americano de estratégia de documentação, Eastwood (2001) considera que o mesmo,

"presume que as instituições arquivísticas e os programas têm responsabilidade coletivamente em preservar um corpo de documentos que representem e reflitam todas as esferas da atividade humana em um dado período. (...) Os elementos chaves desta abordagem são uma análise do universo a ser documentado, um entendimento dos problemas documentários inerentes, e a formulação de um plano para assegurar a adequada documentação de um objetivo, atividade ou área geográfica."

No encontro anual da Sociedade de Arquivistas Americanos (Society of American Archivists) em 1995, Terry Abraham fez uma avaliação da "estratégia de documentação", elencando as várias críticas feitas pelos teóricos contemporâneos, como Angelika Menne-Haritz (1994), "a matéria prima com a qual trabalhamos não permite realizar o ambicioso propósito de conseguir uma retrato o mais verdadeiro possível da sociedade" e Terry Cook (1992), "a estratégia pode ser um mecanismo conveniente para localizar fundos negligenciados, mas falha como teoria".

Comparando a estratégia de documentação, com a de aquisição de documentos, Abraham afirma que a primeira parece o Sistema Decimal de Dewey, procurando ordenar todo o universo, enquanto que a segunda, como a Classificação da Biblioteca do Congresso, organiza uma instituição conhecida. Afirma ainda que esta estratégia "tem mais valor como construção teórica que como um guia prático (ou estratégia) para o trabalho diário em uma instituição arquivística." Mas considera como uma contribuição positiva para os arquivistas a incorporação do universo da documentação a seus instrumentos conceituais.

Documentar a sociedade também é a abordagem da chamada estratégia de aquisição, defendida entre outros por Terry Cook, que aponta 
entre outras influências as idéias do arquivista alemão Hans Booms. Segundo Cook (1997), reagindo contra a abordagem arquivística estatal tradicional, Booms defendia que a sociedade deve aprovar a definição de seus próprios valores fundamentais e que estes valores devem ser então espelhados nos documentos de arquivo. Espelhar os valores da sociedade, através das funções do produtor de documentos, é um dos fundamentos da estratégia de aquisição da nova macro-avaliação implementada no National Archives of Canada.

A macro-avaliação tem sido chamada de "terceira via", isto é, uma alternativa para a ênfase de Jenkinson nos critérios do produtor de documentos e a ênfase de Schellenberg nos critérios voltados para uso informativo e de pesquisa, pois conseguiria combiná-las, focalizando também os valores da sociedade no sentido amplo (PIGOTT, 2001). A arquivista canadense Barbara Craig (2004) a conceitua como,

\footnotetext{
"um processo para avaliar e diferenciar os valores e os significados dos produtores de documentos (e os documentos relativos a eles) através da análise das funções, programas, atividades, e estruturas, e interações com a população, cidadãos/clientes/usuários."
}

Esta abordagem se fundamenta na análise das funções e estruturas dos produtores de documentos, portanto avalia os produtores dos documentos (macro-avaliação), antes de avaliar o próprio documento (microavaliação). Conhecida pela expressão "from the top to the bottom" difere da proposta por Luciana Duranti, que parte da análise tipológica do documento, ou, "bottom up".

Comparando a avaliação funcional e macro-avaliação com outras abordagens, Sheperd (1997) afirma que ela envolve as seguintes questões:

“ - Porque estes documentos foram criados - e não o que eles contêm? 
- Como eles foram criados e utilizados pelos usuários originais - e não como eles podem ser utilizados pelos futuros usuários?

- Que funções e delegações do produtor eles contém - e não que estrutura interna e características físicas eles têm?

- O que poderiam documentar - e não que documentação deve ser conservada?

- Quais produtores de documentos são importantes?"

Cook (1997) também a relaciona com o que denomina "revitalização ou redescoberta da proveniência": reinterpretação canadense do princípio da proveniência tornando-o mais conceitual que físico, como é apropriado para a era dos documentos eletrônicos. A "nova" proveniência é também mais funcional que estrutural, como é adequado para uma época em que a estabilidade organizacional está desaparecendo.

Em Québec, Couture (1996) defende uma arquivística conhecida como "integrada", pois estabeleceria uma ligação entre as preocupações administrativas (valores primários dos documentos) e patrimoniais (valore secundários).

Três dos princípios defendidos por Booms, são apontados por Couture (1996), como influências para a arquivística canadense:

- o conhecimentos profundo que o arquivista deve ter do orgão ou pessoa que produziu os arquivos;

- a contemporaneidade de avaliação (avaliar os documentos com uma escala de valores que seja contemporânea a seu período de criação)

- a avaliação que deve permitir se tenha um máximo de informação em um mínimos de documentos

Além do Canadá, a macro-avaliação e a análise funcional, com variações e adaptações, tem sido utilizada na Alemanha (PIVOT project), na Austrália, na Nova Zelândia, na Suiça, Finlândia. 
A partir da explicitação das principais teorias e metologias propostas para avaliação, observamos que as questões que as teorias de avaliação procuraram e ainda hoje procuram responder são, conforme Eastwood (2001): "Qual é o objetivo da avaliação? Quem deve conduzí-la? Quando os documentos devem ser avaliados? Qual é o fundamento para tomar decisões sobre destinação?"

A teoria e a prática arquivísticas continuam buscando soluções satisfatórias para estas questões, defendendo abordagens que propõem:

- maior responsabilidade e atribuições para a instituição produtora ou para o arquivista;

- privilegiar o contexto de produção ou o conteúdo dos documentos;

- utilizar a estratégia de aquisição, ou a estratégia de documentação, avaliando arquivos ou documentando a sociedade;

- avaliar os documentos a partir de determinada fase de seu ciclo de vida ou avaliar a necessidade da produção do documento.

Quanto a questão fundamental "Porque avaliar arquivos? Qual o objetivo da avaliação?" lembramos as afirmações de Menne-Haritz (1994),

"Experiências com os documentos eletrônicos estimulam nossa percepção. Nós vemos claramente que não é simplesmente quantidade, nem espaço, nem custo, que criam a demanda urgente para avaliação. É a necessidade de reduzir redundância. (...) Isto significa que o objetivo da avaliação arquivística, tanto para documentos tradicionais como para os eletrônicos, deveria ser tornar os arquivos eloqüentes (...). Estes objetivos ainda são obscurecidos pelo impacto da tradição."”

Tem se buscado também harmonizar vários princípios defendidos pela tradição arquivística, com as questões que são colocados contemporâneamente para o arquivista, como as reinterpretações feitas por Terry Cook e outros arquivistas do Canadá do princípio da proveniência e por Angelika Menne-Haritz, de idéias defendidas por Schllenberg. 
É significativa a orientação que existe hoje para que todas as decisões e ações tomadas com relação a avaliação e destinação sejam documentadas permitindo que futuramente haja entendimento do que foi produzido, conservado ou eliminado e porque.

Além disso deve-se considerar o processo global de normalização das metodologias e práticas arquivísticas, pois conforme Craig (2004), "se hoje ainda não existe uma norma internacional para avaliação, elementos comuns vão esboçando uma estrutura interna, que pode desenvolver normas no futuro". 


\section{6 - Uma política de arquivos na região do $A B C$ : o fio de Ariadne}

\section{1 - Políticas Públicas e Políticas Públicas de Arquivo}

Há uma estreita relação entre os temas das políticas públicas e dos direitos humanos, afirma Bucci (2002). De fato, a Constituição de 1988, em seu artigo $5^{\circ}$ estabeleceu os direitos do cidadão, propiciando 0 desenvolvimento de políticas públicas para atendê-los. Assim, encontramos em Carvalho (2002), o conceito, "Políticas Públicas são construções de uma coletividade, que visam a garantia dos direitos sociais dos cidadãos que compõem uma sociedade humana. Este é um princípio democrático fundamental".

A ênfase do papel do Estado na formulação e execução de políticas públicas, aparece em Bucci (2002) quando esclarece que estas são, "Programas de ação governamental visando coordenar os meios de ação governamental e atividades privadas para a realização de objetivos socialmente relevantes e politicamente determinados."

Assim, as políticas públicas podem ser consideradas como respostas do Estado aos direitos coletivos da população, ainda que para sua execução possam estar envolvidos agentes privados.

Quanto ao município, afirma Bucci (2001), é necessário considerar,

"no desenvolvimento das políticas públicas locais a total vinculação entre a responsabilidade do Município em promover ações, programas e políticas públicas e seu papel como ente federado responsável por assegurar o respeito aos direitos humanos, especialmente os direitos econômicos, sociais, culturais e ambientais da pessoa humana." 
O estudo desta questão mostra a ênfase dada à definição das ações e metas a realizar, processos e meios para colocá-las em prática, ao lado das normas que Ihes dêem garantia. Assim, para Bucci (2001), "as políticas, diferentemente das leis, não são gerais e abstratas (...) são forjadas para a realização de objetivos determinados."

Em geral considera-se a existência de políticas públicas ligadas à demandas da população ou de um de seus segmentos, mas encontramos em Mattar (2000) um ângulo diferente de ver a questão. Referindo-se ao direito à informação, cita o professor Roberto Nokolsky que analisando política pública afirma, "fomentar o que não acontece espontaneamente é exatamente a razão de ser das políticas públicas”. Aproveitamos esta proposição para falar de política pública de arquivos, pois assim como existe uma política pública de saúde, uma política pública de educação ou uma política pública de meio ambiente, consideramos a validade de uma política pública de arquivos.

O professor Manuel Vázquez, da Argentina e o professor José Maria Jardim, no Brasil, têm se dedicado a esta questão.

Para Jardim (2003), Políticas Públicas Arquivísticas podem ser conceituadas como,

"o conjunto de premissas, decisões e ações - produzidas pelo Estado e inseridas nas agendas governamentais em nome do interesse social que contemplam os diversos aspectos (administrativo, legal, científico, cultural, tecnológico, etc.) relativos à produção, uso e preservação da informação arquivística de natureza pública e privada".

Vázquez (2003), utiliza a expressão, Política de Administração de Documentos, Informação e Arquivo, para designar,

"a política que formula objetivos e propõe os meios apropriados para servir, mediante os documentos de gestão, os direitos e necessidades 
do conjunto da sociedade; das instituições produtoras/receptoras dos documentos; dos interessados individual ou institucionalmente, e, por último, dos pesquisadores, de acordo com legislação e normas." ${ }^{\text {"111 }}$

Considerando as duas proposições temos aqui os elementos constitutivos de uma política, ou políticas públicas nesta área. Os autores encarecem seu caráter social, os diferentes aspectos de que se revestem, legal, cultural, e outros, o caráter dinâmico das políticas públicas.

Quanto à dupla face dos documentos de arquivo, já estudada amplamente nos capítulos anteriores, Vázquez (2003) estabelece uma distinção entre os objetivos que atenderiam às necessidades da administração e os que atenderiam a preocupação com o patrimônio documental. Relacionamos alguns dos objetivos de uma política pública documental no interesse das administrações:

- garantir os direitos do Estado e dos cidadãos, contidos nos documentos de arquivo;

- oferecer informação acessível, no prazo necessário, que sirva para diagnosticar e resolver os problemas da comunidade;

- racionalizar a produção e utilização de recursos documentais;

- conferir transparência democrática aos atos do governo;

- estabelecer uma burocracia a serviço dos cidadãos, sobretudo os mais frágeis (analfabetos, indígenas, idosos, etc.)

Quanto aos objetivos de uma política considerando o patrimônio documental, propõe a conservação e acesso dos documentos de arquivo públicos e privados para pesquisadores e outros interessados.

Para a execução de políticas públicas, preconiza-se o estabelecimento de um conjunto de normas ou regulamentos. No caso das políticas de arquivo, é necessário regulamentar os sistemas integrados de arquivo, a

\footnotetext{
${ }^{111}$ Traduzimos.
} 
gestão dos documentos, nas várias idades de seu ciclo de vida, e ainda estabelecer normas sobre o acesso aos mesmos.

Quanto à questão da legislação arquivística, Jardim (2003) esclarece que se existe realmente necessidade de seu estabelecimento para a definição e implementação das políticas, a sua simples existência não garante as ações concretas que a viabilizem. Para que isto aconteça são necessárias as dimensões política e técnica-científica. Parafraseando os exemplos dados por Jardim, poderíamos dizer, que resolver o problema do acúmulo de documentos é um problema político-gerencial. As decisões de constituir comissões de avaliação e nomeá-las, também são decisões políticas. O processo de avaliação de documentos, inclusive a elaboração de tabelas de temporalidade, são recursos técnico-científicos. A qualidade de sua concepção, as metodologias e práticas utilizadas, podem trazer resultados políticos negativos. O autor considera que estas duas dimensões a política e a técnica - são faces da mesma moeda e que só com o exercício das duas, será possivel formular e viabilizar políticas públicas arquivísticas.

\section{2 - Instituição de uma política pública de arquivos no Grande}

$A B C$

A origem histórica comum, a interdependência para solução de problemas também comuns como o das enchentes, os vínculos e identidades culturais, o fato de ser uma região altamente polarizada, fatores já estudados neste trabalho justificam a realização de ações integradas entre os municípios do $A B C$.

A problemática dos arquivos públicos e a necessidade de gestão destes documentos, são também pontos em comum entre as sete cidades, como demonstramos.

Por isso neste ítem a idéia central é a instituição de uma política pública de arquivos para a região. É necessário ressalvar que não se trata de 
uma proposta de arquivo regional, como já aventado em outras oportunidades e que apontamos neste trabalho: todos os municípios continuariam com a custódia física de seus documentos públicos de arquivo. Esta política pública consistiria no estabelecimento de normas e critérios comuns para o tratamento da documentação e o acesso aos mesmos; na adoção de procedimentos arquivísticos, com a elaboração de instrumentos de trabalho para a classificação, avaliação e descrição dos documentos; na elaboração de Manuais de Serviço, padronizando e racionalizando as rotinas nos arquivos.

Se cada município tem uma estrutura organizacional própria, as funções e competências das administrações municipais são as mesmas, independentemente do porte do município, possibilitando a identificação das séries e tipos documentais para a elaboração dos quadros de classificação e tabelas de temporalidade. Por isso é possivel a normalização de instrumentos de controle e gestão documental.

Quanto à viabilidade de sua execução temos o exemplo do Grupo de Arquivistas Municipais de Madrí, na Espanha. Há vinte e quatro anos este grupo que congrega representantes de "ayuntamentos" do que poderíamos chamar região metropolitana de Madrí, se reune para formular e colocar em prática políticas arquivísticas, estudando a situação dos arquivos e criando instrumentos de trabalho. Na primeira reunião, em 1981, em Alcobendas, havia apenas três arquivistas municipais. Hoje participam 29 "ayuntamentos".

Foram elaborados por eles, Quadros de Classificação comuns, um Manual de Tipologia Documental dos Municípios, e a partir daí, trabalharam com a avaliação e a eliminação dos documentos. Também estudaram e propuseram normas e metodologias de trabalho para os documentos eletrônicos e foi estabelecido o Regulamento dos Arquivos Municipais.

Além dos trabalhos deste grupo - a metodologia utilizada no Manual de Tipologia Documental tem inspirado muitos trabalhos e experiências - os quadros de classificação para atividades-meio do Arquivo Nacional e do 
Sistema de Arquivos do Estado de São Paulo - SAESP e mesmo tabelas de temporalidade do SAESP, com a ampla pesquisa na legislação sobre prazos de guarda dos documentos, os quadros de classificação e tabelas de temporalidade do município de São José do Campos, as experiências e resultados do Sistema de Arquivos da USP - SAUSP, são importantes subsídios para a elaboração das atividades de controle documental nos municípios estudados. Não é preciso começar do zero. Há que se considerar também as experiências pragmáticas realizadas pelos municípios. Esta história deve ser levada em consideração quando da formulação das políticas de arquivo.

É possivel uma política de avaliação documental científica como defende a Arquivística, que atenda os interesses da administração, do pesquisador, da sociedade. Mas vontade política e conhecimento técnicocientífico devem caminhar juntos para que isto seja realizado. Realizá-la como parte de uma política pública de arquivos para a região é o fio de Ariadne que buscamos.

No caso da região do Grande $A B C$, temos as entidades intermunicipais, facilitando a tarefa a ser realizada. O grupo dedicado a formulação e implantação de políticas públicas de arquivo na região, pode ser um dos GTs-Grupos de Trabalho, vinculados à Câmara do Grande ABC e ao Consórcio Intermunicipal do Grande ABC. A Coordenadoria executiva da Câmara acompanha o desenvolvimento dos trabalhos temáticos, viabilizando sua integração, bem como apoio logístico. Dentro dos Eixos Estruturais propostos, o Grupo das Políticas Públicas de Arquivo, poderia ficar no Eixo Estrutural 6, Identidade Regional e Estruturas Institucionais ${ }^{112}$.

As mudanças previstas no projeto em tramitação no Legislativo Federal alterando e transformando os consórcios intermunicipais em consórcios públicos, possibilitarão maior unidade nas políticas determinadas por eles e

\footnotetext{
${ }^{112}$ Ver Anexo 6, Relação dos GTs-Grupos de Trabalho Temáticos congregando os municípios na Câmara e Consórcio Intermunicipal Grande ABC.
} 
permitirão que façam contratações de interesse comum. No caso do estabelecimento de uma política pública de arquivos para a região seria possível captar recursos, contratar assessorias, adquirir softwares para uso conjunto. O que seria muito dispendioso para um único município, seria possível para o conjunto deles.

A gestão arquivística dos documentos em suas várias fases, além das vantagens para as administrações municipais e todos os cidadãos, possibilitaria a preservação do patrimônio documental dos municípios da região.

Além disso, como aponta Jardim (2003),

"as políticas públicas arquivísticas devem apresentar um alto grau de transversalidade, ou seja, de interseção com outras políticas públicas, tendo em vista a informação para execução de cada uma delas".

Portanto, uma política pública arquivística, além de promover a gestão dos documentos, contribuiria para viabilizar outras políticas públicas. 


\section{Considerações Finais}

Colocar o foco nos arquivos públicos dos municípios do Grande ABC, significou tê-los como um fim e um meio ao mesmo tempo. Como nosso objetivo era identificar as políticas e práticas das administrações públicas com relação a seus documentos de arquivo, analisando se estas estavam de acordo com os princípios da Arquivística e com a legislação federal vigente, a dificuldade de encontrar informações e de ter acesso às mesmas fortaleceu minha motivação e a certeza da importância de se buscar formas de gestão eficazes e eficientes para estes documentos.

Além da literatura sobre arquivos, particularmente sobre a avaliação documental, dos estudos sobre o município no Brasil e suas atribuições, foi necessário consultar a legislação e outros documentos das administrações municipais, que se encontravam em suas Câmaras, arquivos e instituições de história e memória, como museus e centros de documentação. Esta tarefa exigiu muitas visitas aos sete municípios da região e o contato com seus funcionários e as diferentes formas de organização e atendimento.

Sair de trem da estação de Santo André para ir a Rio Grande da Serra, passando por Mauá e Ribeirão Pires é observar que a paisagem marcada por indústrias, grandes edifícios e shoppings vai dando lugar a presença do verde, do rural. Mas apesar das diferenças determinadas pelas condições geográficas e históricas e pela evolução política e econômica, há muitas semelhanças quanto ao tratamento da documentação pública por parte das prefeituras municipais estudadas:

- os arquivos localizados à princípio junto com os serviços de protocolo nas sedes do poder executivo municipal, à medida que crescia o volume de documentos sem que houvesse a necessária gestão documental, passaram a ocupar áreas menos valorizadas, transformando-se em depósitos de documentos, mais ou menos organizados. 
- a denominação Arquivo Geral ou Arquivo Central, não corresponde a documentação produzida pelo conjunto da administração, suas várias secretarias e orgãos, com exceção dos processos administrativos. Além deste tipo documental, o que predomina são algumas séries provenientes sobretudo de secretarias-meio como Administração e Finanças. Em geral os Serviços de Arquivo não se consideram responsáveis por outros documentos enviados pelas Secretarias, apenas cedem o espaço para guarda.

- o tratamento dos documentos na fase corrente obedece a critérios empíricos, só existem normas para produção e tramitação para os processos administrativos. O fato de serem autuados no Serviço de Protocolo, o que significa um certo controle e garantia de recuperação dos mesmos, faz com que prolifere sua produção e posterior acúmulo nos arquivos.

- a documentação cartográfica (mapas e plantas), audiovisual e fotográfica (fotografias, filmes e vídeos) e alguns documentos textuais são encaminhados ou recolhidos pelas instituições de história e memória dos municípios. Não se considera aí o princípio arquivístico da organicidade: se por um lado são preservados da destruição, por outro, perdem os laços que os ligavam a outros documentos e a seu contexto de produção.

- os documentos e arquivos merecem atenção apenas quando passam a representar um problema a ser resolvido, dado o volume crescente da documentação e a incapacidade de armazená-la. É então que se decide avaliar os documentos, prática associada muitas vezes ao processo de microfilmagem. Nestes casos não foram observados princípios da Arquivística, como proveniência e organicidade, ou mesmo normas técnicas, como a NBR10519/88, da ABNT-Associação Brasileira de Normas Técnicas, que estabelece critérios de avaliação de documentos. Como a avaliação é feita a partir da massa documental acumulada, sem acompanhamento técnico-científico de profissionais da área arquivística, não se identificam todas as tipologias documentais, não há a preocupação com a amostragem das séries eliminadas, não se produzem quadros de classificação e tabelas 
de temporalidade de documentos que reflitam as funções e atividades dos órgãos produtores. Tampouco é realizada uma amostragem ${ }^{113}$ criteriosa durante a avaliação.

- os decretos municipais que disciplinam o assunto não consideraram, quando mais recentes, ou não foram atualizados, conforme a legislação federal vigente relativa a gestão documentos públicos, como a Lei $\mathrm{n}^{\circ}$ 8.159/91 (Lei de Arquivos), Decreto $\mathrm{n}^{\circ}$ 1.799/96 (que regulamenta a microfilmagem de documentos) e Resoluções do CONARQ-Conselho Nacional de Arquivos, que estabelecem normas e orientam os procedimentos quanto aos arquivos públicos.

- as comissões de avaliação dos documentos, em geral são constituídas com dificuldade. Sendo essencial a participação de representantes da Secretaria de Assuntos Jurídicos, os documentos demonstram que em mais de um município a comissão não foi instalada pela ausência de representantes da mesma.

- as mudanças na administração municipal a cada quatro anos, mesmo que vença o partido no poder, provocam descontinuidade nos trabalhos de avaliação dos documentos. Por isso não existem Tabelas de Temporalidade para o conjunto da administração em nenhum município, nem mesmo para os documentos-meio, o maior volume da documentação produzida. As que já foram feitas carecem de atualização.

- o modelo de arquivo que existe no imaginário da maior parte dos gestores e funcionários é o "arquivo-depósito". Aparecem apenas algumas referências ao Arquivo do Município de Rio Claro e uma ao Arquivo de Santos.

- as iniciativas visando a modernização administrativa, existentes na maioria do municípios, não incluem a questão dos arquivos, nem são ouvidos os responsáveis por eles, no máximo é chamado o responsável pelo Serviço

\footnotetext{
${ }^{113} \mathrm{Na}$ avaliação, a amostragem é o procedimento que permite, por meio de critérios específicos, selecionar documentos considerados representativos do conjunto a que pertencem. (Camargo e Bellotto, 1996).
} 
de Protocolo. Os Serviços de Arquivo em geral ocupam posição periférica na estrutura organizacional, subordinados às Secretarias de Administração que acumulam múltiplas atribuições: Pessoal, Patrimônio, Cemitério, Telefonia, etc. A exceção é São Bernardo do Campo, onde faz parte da Secretaria de Governo. A maior rapidez nas decisões quanto às questões do Arquivo neste município (constituição de comissões, apresentação de resultados pelas mesmas) pode estar ligada a esta condição hierárquica. Lembramos também que apenas neste município o Serviço de Arquivo não funciona em sede adaptada e precária, foram construídas instalações específicas para 0 mesmo em uma área valorizada da cidade, para onde a administração tem planos de transferir sua sede (Paço Municipal).

- a utilização crescente dos documentos eletrônicos (em Diadema houve inclusive, de 2000 a 2004, uma Secretaria de Governo Eletrônico) não determinou o estabelecimento de um política de gestão que considere suas especificidades, sua volatilidade, as possibilidades de perda de informações com as migrações necessárias. Na Lei de Diretrizes Orçamentárias para o exercício de 2005, de São Bernardo do Campo, encontramos entre as Metas e Prioridade definidas, "Introduzir o GED-Gerenciamento Eletrônico de Documentos" ${ }^{\prime 14}$. Entretanto, estudando a questão do gerenciamento dos documentos eletrônicos, Rondinelli (2002) aponta a necessidade de ampliar o que é preconizado pelo GED, estabelecer-se o "Gerenciamento Arquivístico dos Documentos Eletrônicos", prevendo questões como a garantia da autenticidade destes documentos

Vimos que os municípios brasileiros possuem uma autonomia característica, assumindo grande número de atribuições e competências. Entre elas está a de gestão de seus arquivos. Os municípios do Grande ABC que se emanciparam há mais tempo e que por suas dimensões, população e complexidade administrativa acumularam maior volume de documentos,

\footnotetext{
${ }^{114}$ Prefeitura Municipal de São Bernardo do Campo. Jornal Notícias do Municipio- Atos Oficiais, 06 de agosto de 2004.
} 
buscaram as soluções pragmáticas de gestão que estudamos. Estas não correspondem ao que é preconizado pela ciência arquivística e pela legislação sobre arquivos existente. Nos demais, os documentos também se avolumam à espera de solução.

Demonstramos que estes municípios têm raízes históricas comuns e que ainda hoje existem inúmeros vínculos entre eles. Já se verificaram iniciativas de solução de problemas comuns à região pelo estabelecimento de políticas públicas junto ao Consórcio Intermunicipal Grande $A B C$, que viabiliza a integração entre os municípios e a continuidade das mesmas, por isso consideramos a possibilidade de uma política pública de arquivos para os municípios da região do $A B C$. Assim os imperativos de modernização e transparência administrativas seriam contemplados ao mesmo tempo que o patrimônio documental da região seria preservado e acessível a todos os interessados, fortalecendo a identidade local e regional. 


\section{Bibliografia}

\section{Introdução}

ALBERCH FUGUERAS, Ramón e CRUZ MUNDET, José Ramon. Archivese! Los documentos del poder. El poder de los documentos. Madrid: Alianza Editorial, 1999.

HEREDIA HERRERA, Antonia. La Institución Municipal de Tradición Hispana e y sus Archivos. Anais do $10^{\circ}$ Congresso Brasileiro de Arquivologia: rumos e consolidação da arquivologia. São Paulo: Associação dos Arquivistas Brasileiros - Núcleo Regional de São Paulo, 1998 (CD-ROM)

SOUSA, Renato Tarciso Barbosa de. Arquivos administrativos e massas documentais acumuladas: busca de novas soluções para velhos problemas. 1995. Dissertação (Mestrado em Ciência da Informação e Documentação). Universidade de Brasília, 1995.

LOPES, Luís Carlos. Arquivópolis: uma utopia pós-moderna. In: Ciência da Informação: Brasília. v. 22, n. 1, jan/abr. 1993.

\section{A região do Grande $A B C$ - das origens à reintegração}

ALVES, Luís Roberto. Culturas do Trabalho - Comunicação para a Cidadania. Santo André, Alpharrabio Edições, 1999.

BERBEL, Luiz Carlos. Avaliação de uma iniciativa de gestão regional: o caso MOVA. 2001. Dissertação (Mestrado em Administração). Centro de Estudos de Aperfeiçoamento e Pós-Graduação. IMES - Centro Universitário Municipal de São Caetano do Sul.

BERNARDO, Alessandro Zanoli. Dez anos de políticas regionais no $A B C$ : uma leitura a partir da teoria, da pesquisa e da prática. In: Políticas 
Públicas e Juventude. Caderno de Pesquisa CEAPOG-IMES, ano 03, n 5 , $2^{\circ}$ semestre de 2001, Centro Universitário Municipal de São Caetano do Sul.

CASTRO, José Nilo de. Direito Municipal Positivo. $5^{\mathrm{a}}$ ed., Belo Horizonte, Del Rey, 2001.

DANIEL, Celso. População é que decidirá o futuro. In: Nosso Século XXI. Especialistas de diferentes atividades analisam o Grande ABC de ontem, hoje e amanhã. Santo André: Editora Livre Mercado, 2001.

GOMES, Edgard de Nóbrega. Crescimento e crise da economia no ABC Paulista. Dissertação (Mestrado em Ciências Econômicas - Faculdade de Economia e Administração), Pontifícia Universidade Católica de São Paulo, 1993.

KLINK, Jeroen Johannes. O novo regionalismo - O caso da região do Grande ABC. Tese (Doutorado - Faculdade de Arquitetura e Urbanismo). Universidade de São Paulo, 2000.

MARTINS, José de Souza Martins. Subúrbio. Vida cotidiana e história no subúrbio da cidade de São Paulo: São Caetano, do fim do Império ao fim da República Velha. São Paulo, SP: Hucitec/Unesp, 2002, $2^{\text {a }}$. ed.

MONTEIRO, Arlete Assumpção. Santo André: dos primórdios à industrialização. Um estudo sobre os imigrantes ao longo da São Paulo Railway. Tese (Doutorado - Faculdade de Filosofia, Letras e Ciências Sociais). Universidade de São Paulo, 1995.

PASSARELLI, Silvia Helena F. Bibliografia comentada: Santo André e a região do $A B C$. Trabalho de Pós-Graduação. (Faculdade de Arquitetura e Urbanismo). Universidade de São Paulo, 1993.

Diálogo entre o trem e a cidade: 0 caso de Santo André. Dissertação (Mestrado - Faculdade de Arquitetura e Urbanismo). Universidade de São Paulo, 1994.

RODRIGUES, Marly. Santo André - Cidades e Imagens. Prefeitura Municipal de Santo André, 1991. 
SANTOS, Wanderley dos. Antecedentes Históricos do ABC Paulista: 1550-1892. São Bernardo do Campo. SECE/Prefeitura Municipal de São Bernardo do Campo, 1992.

História do Município de Diadema. Diadema. FAD - Faculdade Diadema - Escola Superior de Ensino, 2000.

3. As administrações públicas municipais no $A B C$ e seus arquivos

AFFONSO, Rui. Os municípios e os desafios da federação no Brasil. In: São Paulo em Perspectiva, O novo município - economia e política local, n 3. jul.set./1996, Fundação SEADE, vol.10. Rio de Janeiro: 1996.

ALBERCH FUGUERAS, Ramón e CRUZ MUNDET, José Ramon. Archivese! Los documentos del poder. El poder de los documentos. Madrid: Alianza Editorial, 1999.

Archivos y cultura: manual de dinamización. Gijón. (Astúrias), Ediciones Trea, S.L. 2001.

BELLOTTO, Heloísa Liberalli. Da administração à História: ciclo vital dos documentos e função arquivística. In: Arquivos Permanentes: tratamento documental. 2a ed. Rio de Janeiro: Editora FGV, 2004. - Arquivos Pessoais em face da teoria arquivística tradicional: debatendo Terry Cook. In: Estudos Históricos, Rio de Janeiro: Fundação Getúlio Vargas, n² 21, 1998.

Em http://www.cpdoc.fgv.br/revista. Acesso em 07/09/2004.

Arquivística. Objetos, Princípios e Rumos. São Paulo: Associação de Arquivistas de São Paulo, 2002.

BILLOTA, Sérgio (et al.). As experiências da FUNDAP na área das comunicações administrativas e arquivos, Cadernos FUNDAP, São Paulo, ano $4, n^{\circ} 8$, abril/1984. 
CAMARGO, Ana Maria de Almeida; BELLOTTO, Heloísa Liberalli (coord.) Dicionário de terminologia arquivística. São Paulo: Associação dos Arquivistas Brasileiros/Núcleo Regional de São Paulo: Secretaria de Estado da Cultura, 1996.

CAMARGO, Ana Maria de Almeida. Sobre o valor histórico dos documentos. In: Revista do Arquivo de Rio Claro, Rio Claro (SP), n.1, p.11 a 17, 2003.

CASTRO, José Nilo de. Direito Municipal Positivo. $5^{\text {a }}$ ed., Belo Horizonte, Del Rey, 2001.

COMISSÃO ESPECIAL DE PRESERVAÇÃO DO ACERVO DOCUMENTAL-CEPAD. A importância da informação e do documento na administração pública brasileira. Brasília, DF: Funcep, 1987.

CORTES ALONSO, Vicenta. Manual de Archivos Municipales. Madrid: Asociación Española de Archiveros, Bibliotecários, Museólogos e Documentalistas. 1982.

COSTA, Célia Maria Leite e FRAIZ, Priscilla Moraes Varella. Acesso a informação nos arquivos brasileiros. Estudos Históricos. Rio de Janeiro: Fundação Getúlio Vargas, v.2, n.3, 1989.

Em <http://www.cpdoc.fgv.br/revistas>. Acesso em 15/05/2004.

COSTA, João Bosco Araújo da. A ressignificação do local: o imaginário político brasileiro pós-80. In: São Paulo em Perspectiva. O novo município: economia e política local, $n^{\circ}$ 3. jul.set./1996, Fundação SEADE, vol.10. Rio de Janeiro: 1996.

CRETELLA JR., José. Direito Municipal. Livraria Editora Universitária Forense Ltda, São Paulo, 1975.

FIGUEIRA, Vera Moreira. A viabilização dos Arquivos Municipais. In: A Sistematização de Arquivos Públicos. CASTILHO, Ataliba Nogueira de (org.). Campinas: Editora da Unicamp, 1991. 
FONSECA, Maria Odila. Direito à Informação: acesso aos arquivos públicos municipais. 1996. Dissertação (Mestrado em Ciência da Informação) Universidade Federal do Rio de Janeiro, 1996.

FRANCO, Celina Vargas do Amaral Peixoto Moreira. Uma política de gestão de documentos: preparar a documentação do século $X X$ para 0 século XXI. In: A sistematização de documentos públicos. CASTILHO, Ataliba Nogueira de (org.). Campinas: Editora da Unicamp, 1991.

GASPARINI, Diógenes. Direito Administrativo. São Paulo: Saraiva, 2002, $7^{\mathrm{a}}$ ed.

HEREDIA HERRERA, Antonia. Teoria y Praxis Archivisticas: ?Distanciamento? In: Revista do Arquivo Rio Claro, Rio Claro (SP), n .22, 2004.

INOJOSA, Rose Marie. Comunicação em Arquivologia. Análise do arquivo da prefeitura paulistana como meio de comunicação. Dissertação (Mestrado-Escola de Comunicação e Artes). Universidade de São Paulo, 1980.

JARDIM, José Maria. A face oculta do Leviatã; gestão da informação e transparência administrativa. In: Revista do Serviço Público, Brasília, 119 (1): jan/abr. 1995.

- Transparência e Opacidade do Estado no

Brasil: usos e desusos da informação governamental. Niteroi: EdUFF, 1999.

LOPES, Luís Carlos. A informação e os arquivos: teorias e práticas. Niterói: EDUFF; São Carlos: EDUFSCAR, 1996.

MALIN, Ana. Economia e Política da Informação, novas visões da História. In: São Paulo em Perspectiva. Informação, Saber e Mudança. v. 8, $n^{\circ}$ 4, out-dez/94, Revista da Fundação Seade.

MACHADO, Helena Corrêa e CAMARGO, Ana Maria de Almeida. Como implantar arquivos públicos municipais. São Paulo, SP: Arquivo do Estado, 1999. 
MELO, Marcus André. Crise Federativa, Guerra Fiscal e "Hobbesianismo Municipal"- efeitos perversos da descentralização? In: São Paulo em Perspectiva, O Novo Município - economia e política local, Vol. 10, nº 03, Fundação Seade. São Paulo: 1996.

MEIRELLES, Hely Lopes. Direito Municipal Brasileiro, Vol. I, Ed. Revista dos Tribunais, São Paulo, 1964 - Direito Constitucional Brasileiro. São Paulo. Ed. Revista dos Tribunais, 1977.

Direito Administrativo Brasileiro. São Paulo: Saraiva, 2000.

OLIVEIRA, Daíse Apparecida (et al). Cooperação e Integração dos Arquivos Municipais da Ibero-América e do Caribe: $O$ caso de Londrina Paraná - Brasil. Londrina, PR: Universidade Estadual de Londrina, s.d.

Como organizar Arquivos

Públicos Municipais (Planos de Classificação e Tabelas de Temporalidade). Manual da Oficina. Projeto Como Fazer. Associação de Arquivistas do Estado de São Paulo Arquivo do Estado de São Paulo. São Paulo. 24/25 de outubro de 2002.

REIS, José Carlos Vasconcellos dos. Os municípios no Estado Federal Brasileiro: Algumas considerações ante a nova Lei de Diretrizes Urbanas. In: Revista de Direito Administrativo, Rio de Janeiro: Editora Renovar Ltda. n. 228, abril/junho, 2002.

SALGADO, Sílvia Regina da Costa. Um usuário muito especial: a informação enquanto recurso para a administração municipal. Dissertação (Mestrado-Escola de Comunicação e Artes). Universidade de São Paulo, 1989.

SCHELLENBERG, Theodore. Problemas arquivísticos do Governo Brasileiro. Rio de Janeiro: Arquivo Nacional, 1960.

SOARES, Nilza Teixeira e SANTOS, Frederico Silveira. Avaliação de documentos arquivísticos. Caminhos percorridos. Anais do $10^{\circ}$ Congresso 
Brasileiro de Arquivologia: rumos e consolidação da arquivologia. São Paulo: Associação dos Arquivistas Brasileiros - Núcleo Regional de São Paulo, 1998 (CD-ROM)

SOUSA, Renato Tarciso Barbosa de. Arquivos administrativos e massas documentais acumuladas: busca de novas soluções para velhos problemas. 1995. Dissertação (Mestrado em Ciência da Informação e Documentação). Universidade de Brasília, 1995.

VALLETE, Jean-Jacques. $O$ papel dos arquivos na administração e na política de planificação nos países em desenvolvimento. Rio de Janeiro: Arquivo Nacional, 1973

\section{Iniciativas de gestão documental: a tarefa de Sísifo}

BELLOTTO, Heloísa Liberalli. Arquivística. Objetos, Princípios e Rumos. São Paulo: Associação de Arquivistas de São Paulo, 2002.

\section{Como desenvolver políticas de ação} cultural e educativa em arquivos (Manual). São Paulo: Associação de Arquivistas do Estado de São Paulo, 2002.

. Da administração à História: ciclo vital dos documentos e função arquivística. In: Arquivos Permanentes: tratamento documental. $2^{\mathrm{a}}$ ed. Rio de Janeiro: Editora FGV, 2004.

CAMARGO, Ana Maria de Almeida; BELLOTTO, Heloísa Liberalli (coord.) Dicionário de terminologia arquivística. São Paulo: Associação dos Arquivistas Brasileiros/Núcleo Regional de São Paulo: Secretaria de Estado da Cultura, 1996.

DELSALLE, Paul. Une histoire de I'Arquivistique. Québec: Presses de l'Université du Québec, 1998.

FRANCO, Celina Vargas do Amaral Peixoto Moreira. Uma política de gestão de documentos: preparar a documentação do século XX para o 
século XXI. In: A sistematização de documentos públicos. CASTILHO, Ataliba Nogueira de (org.). Campinas: Editora da Unicamp, 1991.

LOPES, Luís Carlos. O arquivista hermeneuta. In: Cenário Arquivístico. v.1, jan/jun., Brasília: Associação Brasiliense de Arquivologia, 2002.

RONDINELLI, Rosely Curi. Gerenciamento Arquivístico de Documentos Eletrônicos: um abordagem teórica da diplomática arquivística contemporânea. Rio de Janeiro: Ed. FGV, 2002.

ROUSSEAU, Jean-Yves e COUTURE, Carol. Os fundamentos da disciplina arquivística. Lisboa: Publicações Dom Quixote, 1998.

SCHELLENBERG, Theodore R. Arquivos Modernos: princípios e técnicas. $2^{a}$ ed. Rio de Janeiro, Fundação Getúlio Vargas, 2002.

SILVA, Armando Malheiro da. (et al). Arquivística - Teoria e Prática de uma Ciência da Informação. v. 1. Porto: Edições Afrontamento, 1999.

SOARES, Nilza Teixeira. Administração e controle da produção documental em função da pesquisa, avaliação e eliminação de papéis. In: Anais do I Congresso Brasileiro de Arquivologia. Rio de Janeiro: Associação dos Arquivistas Brasileiros, 1972.

SOUSA, Renato Tarciso Barbosa de. Arquivos administrativos e massas documentais acumuladas: busca de novas soluções para velhos problemas. 1995. Dissertação (Mestrado em Ciência da Informação e Documentação). Universidade de Brasília, 1995.

VÁZQUEZ, Manuel. Estúdio del ciclo vital de los documentos. Córdoba: 1987. 
5. Avaliação documental: principais abordagens teóricas e metodológicas

ABRAHAM, Terry. Documentation Strategies: A decade (or more) later. (Meeting of the Society of American Archivists, Washington, D.C., 1995. Em <http://www.uidaho.edu/special-collections/paper/dcstr10.ht > Acesso em 07/09/2004.

BELLOTTO, Heloísa Liberalli. Arquivos públicos: avaliação e eliminação de documentos. In: Ciência e Cultura (Revista da Sociedade Brasileira para o Progresso da Ciência) 42 (10): 745-749, outubro 1990.

BERNIER, Hélène. Le Tri Archivistique. Les Dossiers d'élèves à la Comission Scolaire de Chutes-de-la-Chaudière. In: Archives, vol. 27, $\mathrm{n}^{\circ} 1$, 1995.

Em <www.archivistes.qc.ca/revuearchives>. Acesso em 07/09/2004

CAMARGO, Ana Maria de Almeida; BELLOTTO, Heloísa Liberalli (coord.) Dicionário de terminologia arquivística. São Paulo: Associação dos Arquivistas Brasileiros/Núcleo Regional de São Paulo: Secretaria de Estado da Cultura, 1996.

COOK,Terry. Archival Appraisal and Collection: Issues, Challenges, New Approaches. Archival Studies University of Manitoba: 1999.In: <www.mybestdocs.com/cookt nara 990421 2.htm. Acesso em 07/08/2004.

What is Past is Prologue: a History of Archival Ideas Since 1898, and the Future Paradigm Shift. 1997.

Em <http://aca.archives.ca/publicat/archivaria/index.htm>. Acesso em $12 / 10 / 2004$.

COUTURE, Carol. Les fondements théoriques de l'évaluation des archives. In: 3e. Symposium en Archivistique: I'évaluation des archives: 
des necessités de la gestion aux exigences du témoignage. Université de Montreal/Groupe Interdisciplinaire de Recherche en Archivistique, 1998. . L'évaluation des archives. État de la question. In:

Archives, v.28, n¹, 1996/1997.

Em<http://www.archivites.qc.ca/recuearchives/vol28 1/28-1-Couture.pdf> Acesso em 07/09/2004.

CRAIG, Barbara. Archival Appraisal: Theory and Practice. München, K.G. Saur, 2004.

DURANTI, Luciana. Cunningham`s Commentary. 1997.

$\mathrm{Em}<$ http://lists.archivists.org.au/pipermail/archvists.or.au $>$ Acesso em $31 / 10 / 2004$. . The concept of appraisal and archival theory. The American Archivist, Chicago (II), v. 57, n² 2, 1994.

EASTWOOD, Terry. Thinking on Archival Appraisal in the Europe and North America: A Critical Analysis.

Em<http://rikar.org/archivist/bbs/datas/a pds/fils/20011030195906/eastwood. hwp.rtf> Acesso em 12/10/2004.

FERNÁNDEZ, José Bernal Rivas. La valoración: Fundamento teórico de la Archivística. In: Biblios. Revista Electrónica de Ciências de la Información. n. 12, abril-junho, 2002.

Em <http://bibliotecas.rcp.net.pl.biblios>. Acesso em 15/08/2004.

HOUAISS, Antonio. e VILLAR, Mauro Salles. Dicionário Houaiss da Língua Portuguesa. Rio de Janeiro: Editora Objetiva, 2004.

KROMNOV, Ake. Avaliação de documentos Contemporâneos. Revista Arquivo e Administração. Rio de Janeiro, 9(3): 16-20, set/dez.1981 LYBECK, Jari. Appraisal 2000: A project of the Finnish National Archives and its international context.

Em http://www.nasc.fi/tambere/1.html. Em 07/08/2004. 
MACHADO, Helena Corrêa e CAMARGO, Ana Maria de Almeida. Como implantar arquivos públicos municipais. São Paulo, SP: Arquivo do Estado, 1999.

NAA-NATIONAL ARCHIVES OF AUSTRALIA. <http://www.aa.gpv.an> Em 06/06/2004.

MENNE-HARITZ, Angelika. What can be achieved with archives? In: The concept of record: report from the Second Stockholm Conference on Archival Science and the Concept of Record, 30-31, May, 1996. Stockholm: Riksarkivet, 1998, p. 11-24.

Appraisal or documentation: can we appraisal archives by selecting content? The American Archivist, Chicago, v. 57, n. $3,1994$.

MINISTÉRIO DA JUSTIÇA. Arquivo Nacional. Orientação para avaliação e arquivamento intermediário em arquivos públicos. Publicações Técnicas 41, Rio de Janeiro, 1985.

NAHUET, Robert. Une théorie del'évaluation. Quelques élèments de réflexion. Archives, volume 28, n 1, 1996-1997.

Em <www.archivistesqc.ca./revuearchives $>$ Acesso em 07/09/2004.

PIGGOTT, Michael. Appraisal: tjhe state of the art. Workshop on ASA-South Australia Branch, 2001.

Em <http//:www.archivists.org.au/sem/mise/pigott/html> Acesso em 2005..

SAMUELS, Helen Willa. Documentando a Química moderna: a tarefa histórica do Arquivista. Trad. de Liliane Schrank Lehman de Barros. Boletim do Arquivo, Arquivo do Estado de São Paulo, São Paulo, v. 2, $n^{0}$ 1/2, jan/dez, 1993.

SCHELLENBERG, Theodore R. Arquivos Modernos: princípios e técnicas. $2^{\mathrm{a}}$ ed. Rio de Janeiro, Fundação Getúlio Vargas, 2002.

SHEPERD, Elizabeth. Theories of appraisal. The School of Library, Archive and Information Studies. University College London. 1997. 
Em <http://www.ucl.ac.uk/SLAIS/projects/level1.htm> Acesso em $31 / 10 / 2004$

SILVA, Armando Malheiro da. (et al). Arquivística - Teoria e Prática de uma Ciência da Informação. v. 1. Porto: Edições Afrontamento, 1999.

VÁZQUEZ, Manuel. Como seleccionar documentos de archivo. Córdoba: Ad Sidera Editorial, 2002.

6 - Uma política pública de arquivos para a região do $A B C$ : 0 fio de Ariadne

BERBEL, Luiz Carlos. Avaliação de uma iniciativa de gestão regional: o caso MOVA. 2001. Dissertação (Mestrado em Administração). Centro de Estudos de Aperfeiçoamento e Pós-Graduação. IMES - Centro Universitário Municipal de São Caetano do Sul.

BUCCI, Maria Paula Dallari. Buscando um conceito de Políticas Públicas para a Concretização dos Direitos Humanos. In: Direitos Humanos e Políticas Públicas. São Paulo. Pólis, 2001. (Cadernos Polis, 2)

Em <http://www.polis.org.br/obras/arquivo 90.pdf> Acesso em 07/02/2005.

\section{Direito Administrativo e Políticas}

Públicas. São Paulo: Editora Saraiva, 2002.

CARVAlHO, Alysson (org.) Políticas Públicas. Belo Horizonte: Ed. UFMG, 2002.

CONSÓRCIO INTERMUNICIPAL DO GRANDE ABC. Retratos Metropolitanos. A experiência do Grande ABC em perspectiva comparada. Santo André: Consórcio Intermunicipal do Grande ABC e Fundação Konrad Adenauer, 2002.

JARDIM, José Maria. As novas tecnologias da informação e o futuro dos arquivos. In: Estudos Históricos, Rio de Janeiro, vol. 5, n.10, 1992. 
O inferno das boas intenções: legislação e políticas arquivísticas. In: Acesso à informação e política de arquivos. Eliana Mattar, organizadora. Rio de Janeiro: Arquivo Nacional, 2003.

MATTAR, Eliana da Silveira. A dimensão legal do acesso à informação arquivística.

Em<http://www.arquivo.nacional.br/pub/virtual/conf_seminario/conferencia eliana.htm> Acesso em 12/10/2004.

RODRÍGUEZ BARREDO, Júlia Maria. (org.) 20 Años del Grupo de Archiveros Municipales de Madrid. Ayuntamiento de Alcobendas, 2001.

VÁZQUEZ, Manuel. Política de la Administración de Documentos y Archivos. Córdoba: Instituto Superior Bancario, 2003.

. Política Arquivística. In: Arquivo Rio Claro, Rio Claro (SP), 10-22, jan.91-jan. 93.

\section{Periódicos:}

- Informativo Grande ABC, Consórcio Intermunicipal Grande ABC, ano 3, n 10, Abril/Maio 2001, Santo André.

- "A região encontra soluções", Revista Câmara ABC, Agência de Desenvolvimento Econômico do Grande $A B C$ e Câmara do Grande $A B C$, 2000, Santo André.

- "Laboratório do Imes estudará a região". Diário do Grande ABC, 09/05/1998, p.4 (Cad. Regional)

-“Família Mauaense”, Coluna Memória, Ademir Médici, Diário On Line, 18/04/2004.

Em<http://www.dgabc.com.br/colunas/memoria.htm> Acesso em 18/04/2004. 


\section{LEGISLAÇÃO}

BRASIL. Constituição da República Federativa do Brasil, 1988.

SANTO ANDRÉ, SÃO BERNARDO DO CAMPO, SÃO CAETANO DO SUL, DIADEMA, MAUÁ, RIBEIRÃO PIRES E RIO GRANDE DA SERRA. Leis Orgânicas Municipais.

\section{Legislação sobre Arquivos}

BRASIL. Lei 8.159, de 08 de janeiro de 1991, dispõe sobre a Política Nacional de Arquivos Públicos e Privados

BRASIL. Resolução CONARQ - Conselho Nacional de Arquivos, n 5 , de 30 de setembro de 1996, dispõe sobre a publicação de editais para eliminação de documentos nos Diários Oficiais da União, Distrito Federal, Estados e Municípios

BRASIL. Resolução CONARQ - Conselho Nacional de Arquivos, $n^{\circ} 6$, de 15 de maio de 1997, dispõe sobre diretrizes quanto à terceirização de serviços arquivísticos públicos.

BRASIL. Resolução CONARQ - Conselho Nacional de Arquivos, $\mathrm{n}^{\circ} 7$, de 20 de maio de 1997, dispõe sobre os procedimentos para a eliminação de documentos no âmbito dos órgãos e entidades integrantes do Poder Público.

\section{Legislação sobre Microfilmagem de Documentos}

Lei $5.433 / 68$, de 8 de maio de 1968, regula a microfilmagem de documentos oficiais e dá outras providências

Decreto $n^{\circ} 64.398$, de 24 de abril de 1969, regulamenta a Lei $n .^{\circ} 5433$. de 8 de maio de 1968, que regula a microfilmagem de documentos oficiais, e dá outras providências. 
Decreto $\mathrm{n}^{\circ} 1.799$, de 30 de janeiro de 1996, regulamenta a Lei $n .^{\circ}$ 5433. de 8 de maio de 1968, que regula a microfilmagem de documentos oficiais, e dá outras providências.

\section{Legislação sobre a Estrutura Administrativa dos Municípios}

SANTO ANDRÉ. Lei n 8.459, de 20 de dezembro de 2002, dispõe sobre a reorganização da estrutura administrativa com a extinção, criação e transformação de cargos da Administração Pública Municipal de Santo André e dá providências correlatas.

SÃO BERNARDO DO CAMPO. Lei $n^{\circ} 2.240$, de 13 de agosto de 1976, dispõe sobre a organização dos serviços da Prefeitura, criação de cargos e fixação de vencimentos do pessoal e dá outras providências; modificada pela Lei $n^{\circ} 3058$ de 19 de maio de 1988 e pela Lei $n^{\circ} 3.836$, de 8 de novembro de 1991.

SÃO CAETANO DO SUL. Lei $n^{\circ} 1.489$, de 22 de agosto de 1966, dispõe sobre a organização dos serviços da Prefeitura, criação de cargos e fixação de vencimentos do pessoal e dá outras providências.

DIADEMA. Lei $n^{\circ}$ 05/60, dispõe sobre a organização dos serviços da Prefeitura, criação de cargos e fixação de vencimentos do pessoal e dá outras providências.

DIADEMA. Lei Complementar $\mathrm{n}^{\circ}$ 0036, de 17 de março de 1995, dispõe sobre a reorganização administrativa e reestruturação dos quadros de pessoal da Prefeitura Municipal de Diadema.

MAUÁ. Lei 3.467 de 07/02/2002, dispõe sobre a organização dos serviços da Prefeitura, criação de cargos e fixação de vencimentos do pessoal e dá outras providências, modificada pela Lei Complementar $n^{\circ} 01$, de 08/03/2002.

RIBEIRÃO PIRES. Lei 4659/2002, dispõe sobre a reorganização administrativa da Prefeitura Municipal da Estância de Ribeirão Pires. 
RIBEIRÃO PIRES. Lei 4.517/2001, dispõe sobre a criação de cargos e salários de pessoal da Prefeitura Municipal da Estância de Ribeirão Pires.

RIO GRANDE DA SERRA. Lei $n^{\circ}$ 1222, de 20 de agosto de 1999, dispõe sobre a reorganização administrativa da Prefeitura Municipal de Rio Grande da Serra.

\section{Legislação sobre gestão documental nos municípios}

SANTO ANDRÉ. Decreto $n^{\circ}$ 9331, de 08 de junho de 1978, dispõe sobre a constituição do Grupo Inter-Secretarial de Liberação de Papéis e Documentos - GISELPA

SANTO ANDRÉ. Decreto $n^{\circ} 12.660$, de 28 de janeiro de 1991, dispõe sobre o Arquivo Interno da Prefeitura de Santo André e dá outras providências.

SÃO BERNARDO DO CAMPO. Decreto $n^{\circ} 4373$, de 16 de julho de 1975, dispõe sobre a constituição do Grupo Inter Setorial de Liberação de Papéis e Documentos - GILPA

SÃO BERNARDO DO CAMPO. Decreto $n^{\circ} 5589$, de 15 de junho de 1977, dispõe sobre a destruição e incineração de papéis e dá outras providências.

SÃO BERNARDO DO CAMPO. Decreto $n^{\circ} 6.751$, de 18 de fevereiro de 1981, autoriza a microfilmagem de processos administrativos e dá outras providências

SÃO CAETANO DO SUL. Lei $n^{\circ}$ 3.975, de 25 de junho de 2001, institui o GRAAL - Gerenciamento Reunido de Análises Logísticas

DIADEMA. Decreto $n^{0} 5.162$, de 24 de maio de 1999, que regulamenta as alíneas "d" e "e" da Lei Complementar 0036, de 17 de março de 1995, cria a Comissão de Avaliação de Processos Documentos, estabelece normas 
para avaliação e destinação de documentos e dá outras providências, modificado pelo Decreto $n^{\circ} 5.192 / 99$, de 20 de agosto de 1999.

\section{Legislação sobre Instituições de Memória e História da região do}

\section{Grande ABC}

SANTO ANDRÉ. Lei $n^{\circ}$ 5.942, de 03 de agosto de 1982, dispõe sobre a criação do Museu de Santo André.

SÃO BERNARDO DO CAMPO. .Lei n 3.104, de 27 de junho de 1988, dispõe sobre as atribuições do Departamento de Cultura.

SÃO BERNARDO DO CAMPO. Lei $n^{\circ}$ 9.649, de 31 de agosto de 1988, dispõe sobre as atribuições do Serviço de Documentação e História Local.

SÃO CAETANO DO SUL. Decretos 716 e $728 / 59$, dispõe sobre a criação do Museu de São Caetano do Sul.

SÃO CAETANO DO SUL. Lei no 3.147, de 12 de junho de 1991, dispõe sobre a criação da Fundação Pró-Memória de São Caetano do Sul.

DIADEMA. Lei $n^{\circ} 268$, de 31 de janeiro de 1.967, dispõe sobre a criação de Museu Histórico do Município e dá outras providências.

DIADEMA. Lei $\mathrm{n}^{\circ} 124$, de 17 de fevereiro de 1971, dispõe sobre a instalação do Museu Histórico e Pedagógico “João Ramalho”.

MAUÁ. Decreto $n^{\circ} 2.854$, de 27 de outubro de 1982, dispõe sobre a criação do Museu da Cidade de Mauá.

RIBEIRÃO PIRES. Lei n².432, de 06 de abril de 1983, cria o Museu Histórico Municipal.

RIBEIRÃO PIRES. Lei $n^{\circ} 4.681$, de 09 de maio de 2003, cria o Centro de Apoio Técnico ao Patrimônio. 


\section{LISTA DE ANEXOS}

1 - Mapa do antigo município de São Bernardo em 1932, hoje Grande ABC. Fonte: Wanderley dos Santos. Antecedentes Históricos do ABC Paulista: 1550-1892. São Bernardo do Campo: Serviço de Documentação e História Local/Prefeitura Municipal de São Bernardo do Campo, 1992.

2 - Mapa da atual região do Grande ABC, com os municípios de Santo André, São Bernardo do Campo, São Caetano do Sul, Diadema, Mauá, Ribeirão Pires e Rio Grande da Serra.

Fonte: Informativo Grande ABC. Consórcio Intermunicipal Grande ABC, ano 6, n. 21, junho/julho 2004.

3 - Mapa - O Grande ABC na Região Metropolitana de São Paulo Fonte: Informativo Circulandô. Secretaria de Estado dos Transportes Metropolitanos. Ano 6. n.30, 2003.

4 - Quadro Comparativo dos Municípios do Grande ABC. Fonte: Instituto Brasileiro de Geografia e Estatística.

5 - Sede do Consórcio Intermunicipal do Grande ABC, Câmara do Grande ABC e Agência de Desenvolvimento Econômico do Grande ABC. Edifício Prefeito Celso Daniel. Foto Carlos Thorschmidt.

6- Relação dos GTs-Grupos de Trabalho temáticos congregando os municípios do $A B C$, junto a Câmara e o Consórcio Intermunicipal Grande ABC. Fonte: Consórcio Intermunicipal do Grande ABC.

7 - Documento "Em defesa de um Sistema Municipal de Arquivos" elaborado pela Comissão Técnica das Instituições Oficiais de Memória do Grande $A B C$ e entregue a todas as administrações municipais da região, 2002. 


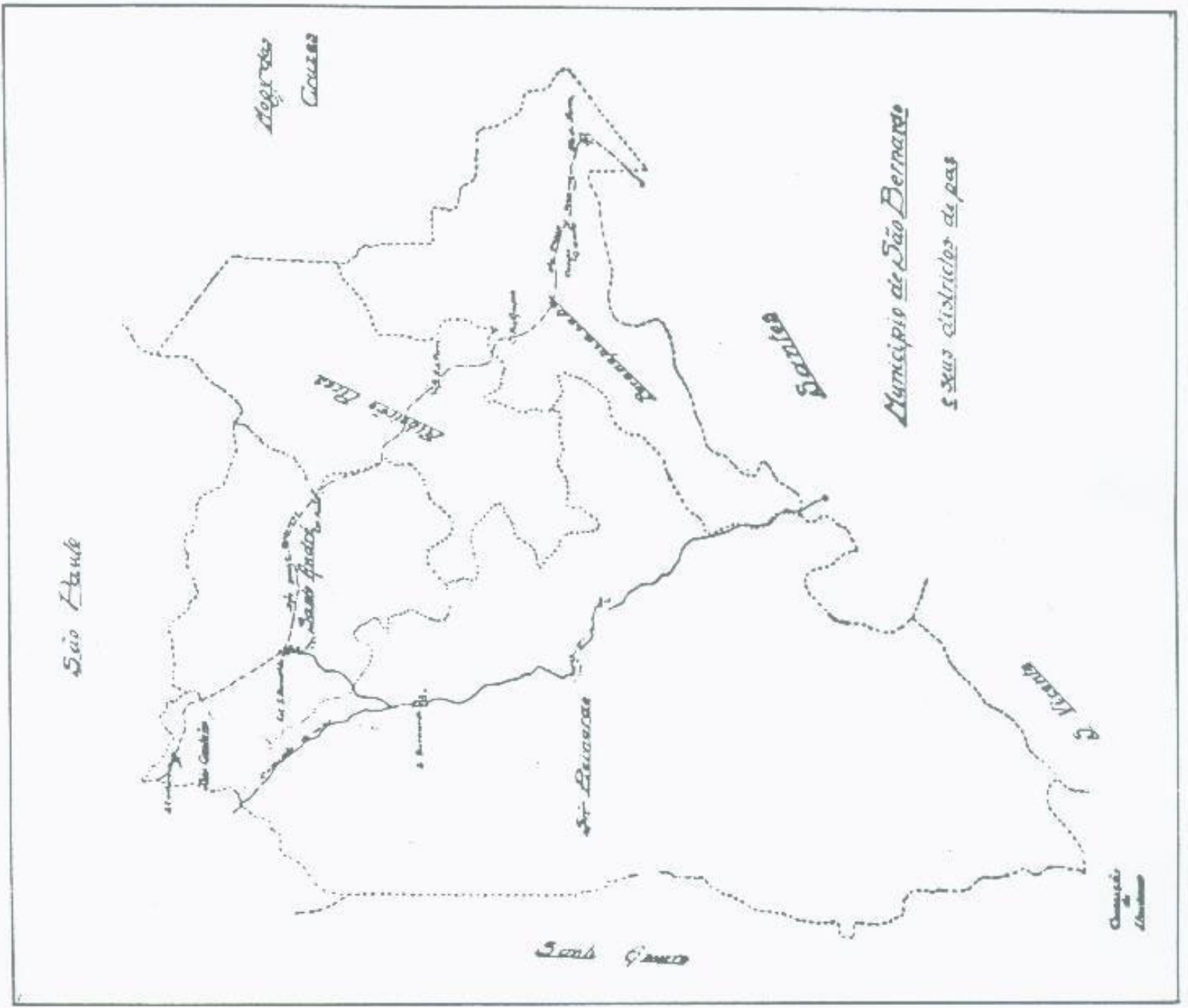

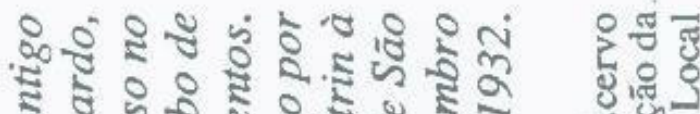

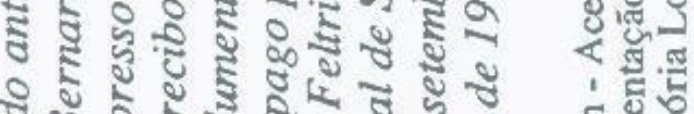
8 का

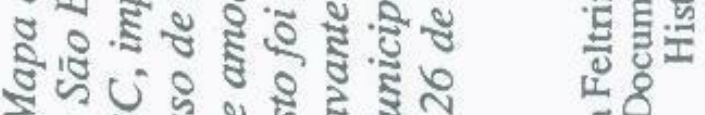

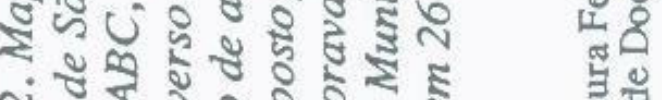
กิं ชิ

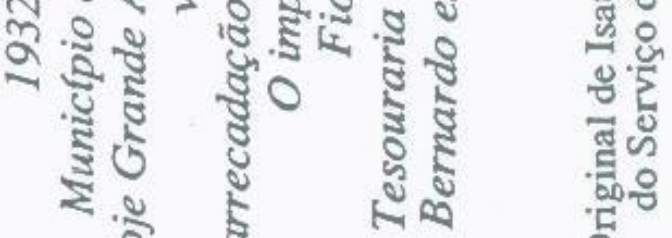
ร ह 


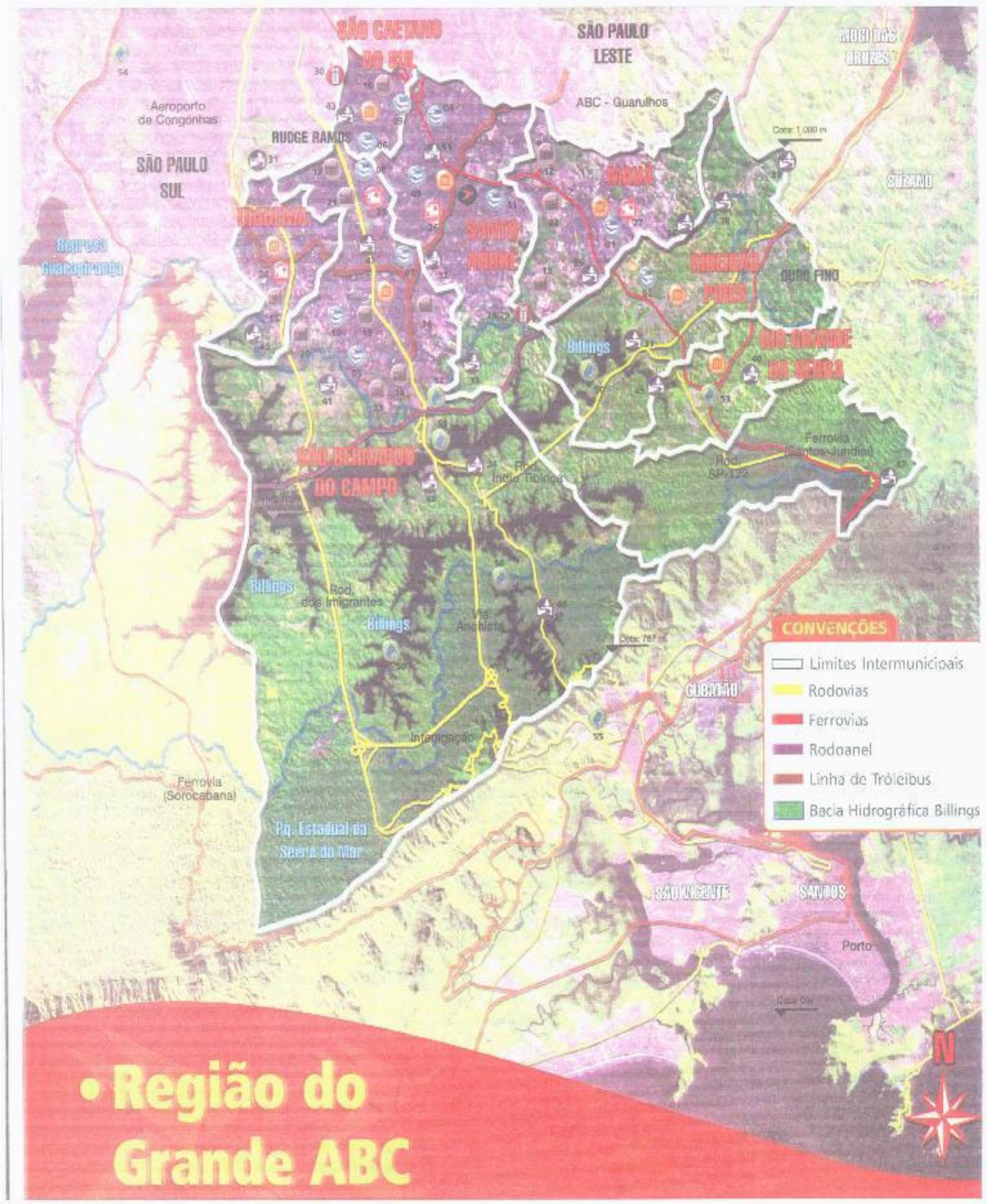



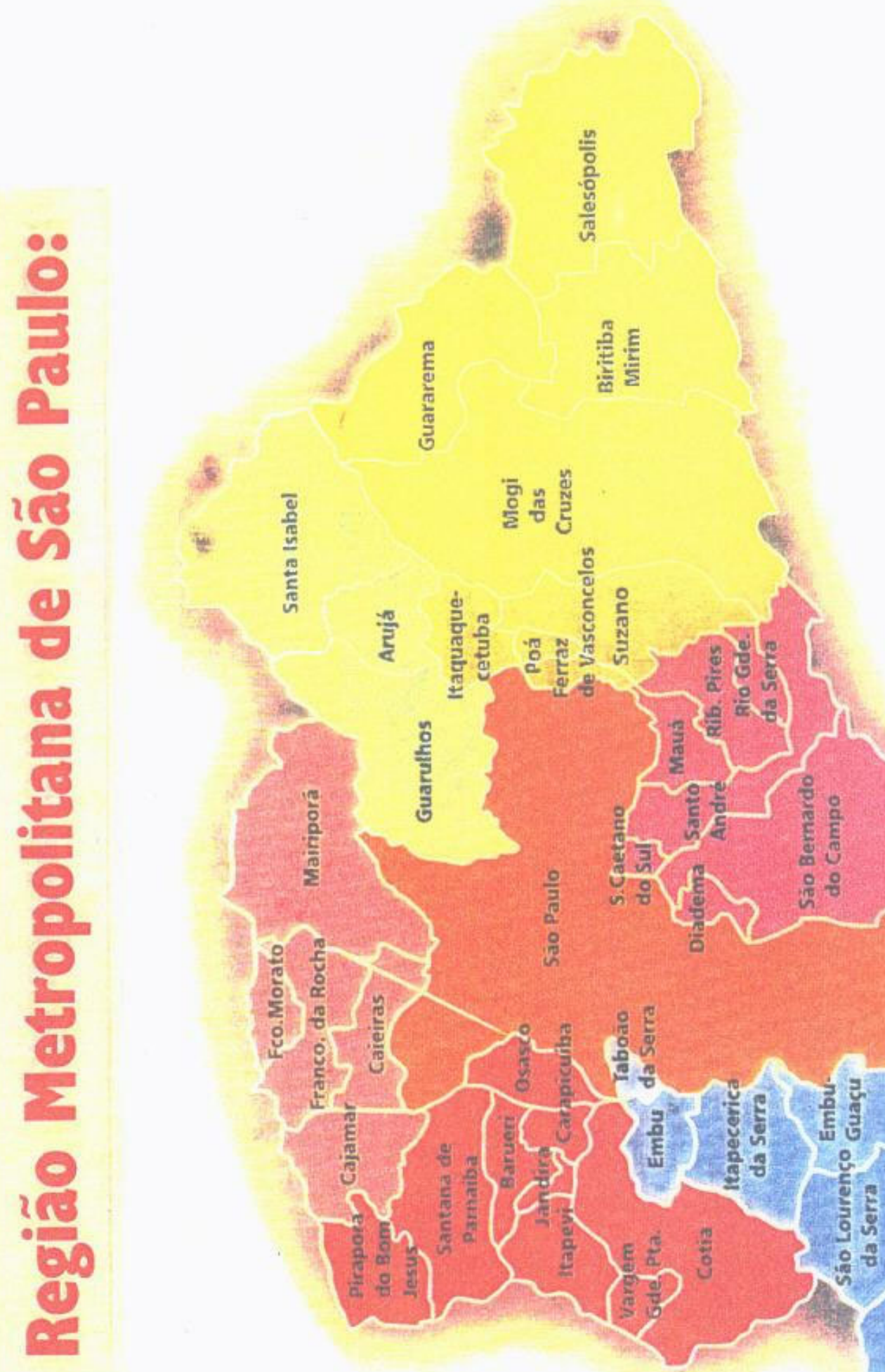


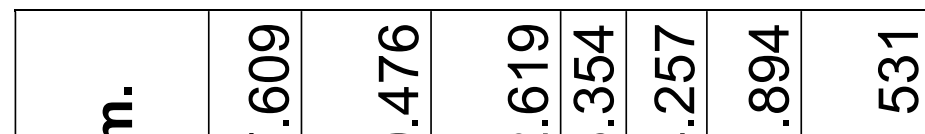
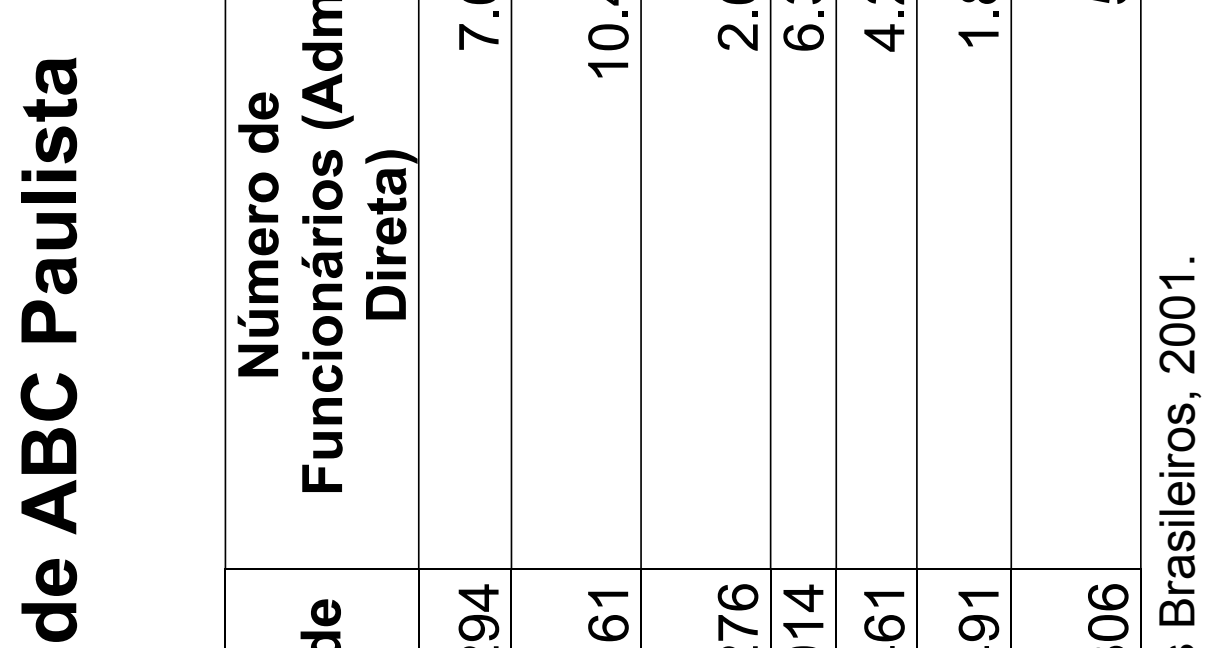

$\frac{0}{0}$

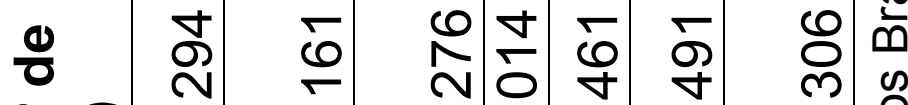

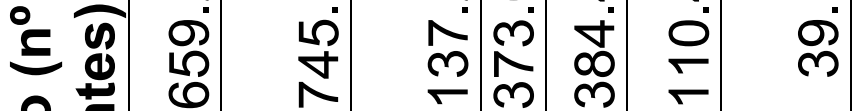

응

0

0 I $N$ N

$2 \pi$

$\frac{\pi}{5} \frac{0}{\pi}$

( )

응 드

$-\frac{0}{0}$

ฉ

(1)

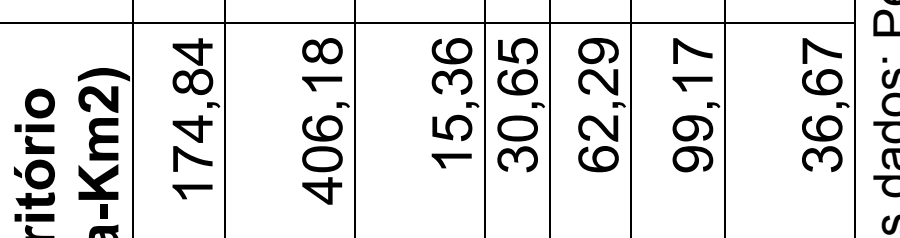

2

I

勾

8

10

(v

10

을

E

1

$\frac{0}{20}$

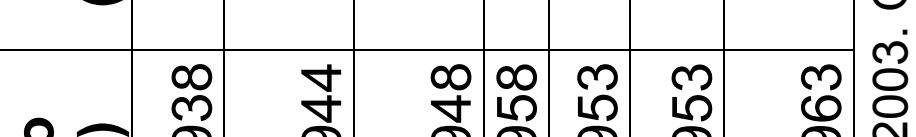

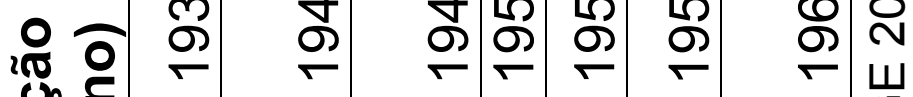

Uु $\frac{5}{\sigma}$ (

重 


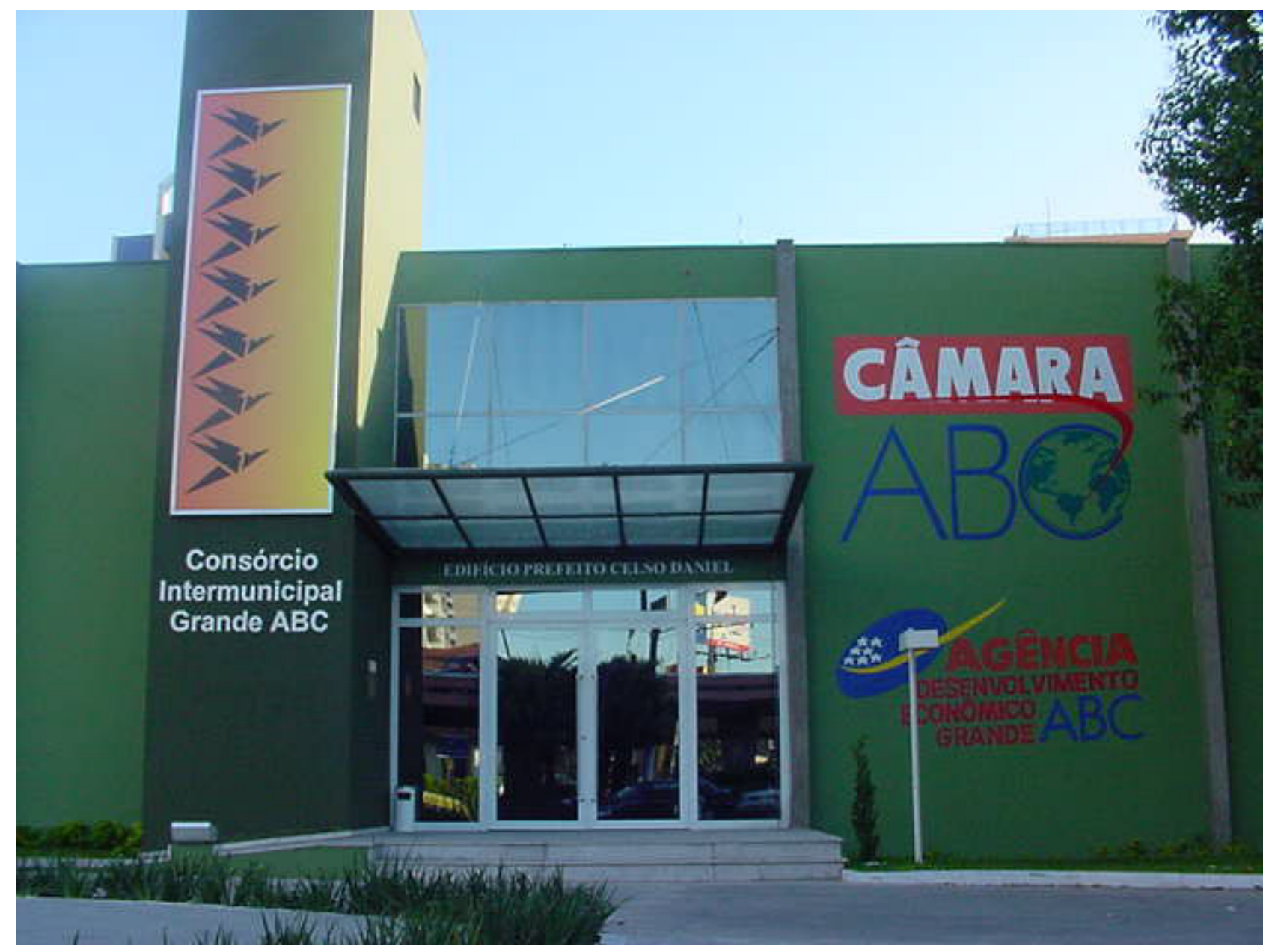

Foto Carlos Thorschmidt

Sede do Consórcio Intermunicipal do Grande ABC, Câmara ABC e Agência do Desenvolvimento Econômico ABC - Edifício Prefeito Celso Daniel -Santo André 


\begin{tabular}{|c|c|}
\hline \multicolumn{2}{|r|}{ GRUPOS TEMÁTICOS } \\
\hline $\mathbf{N}^{\circ}$ & NOMES \\
\hline \multicolumn{2}{|c|}{ EE1-EDUCAÇÃO E TECNOLOGIA } \\
\hline 01 & GT-Parque Tecnológico \\
\hline 02 & GT-Educação $\left(^{*}\right)$ \\
\hline 03 & GT-Mova $\left(^{*}\right)$ \\
\hline 04 & GT-Educação para o Trabalho $\left(^{*}\right)$ \\
\hline \multicolumn{2}{|c|}{ EE-2-SUSTENTABILIDADE DE ÁREAS MANANCIAIS } \\
\hline 05 & GT-Meio Ambiente $\left(^{*}\right)$ \\
\hline 06 & GT-Meio Ambiente - Compensação Financeira $\left(^{*}\right)$ \\
\hline \multicolumn{2}{|c|}{ EE-3-ACESSIBILIDADE INFRA-ESTRUTURA } \\
\hline 07 & GT-Residuos Solidos \\
\hline 08 & GT-Macrodrenagem $\left({ }^{*}\right)$ \\
\hline 09 & GT-Defesa Civil $\left(^{*}\right)$ \\
\hline 10 & GT-Sistema Viario e Circulação $\left(^{*}\right)$ \\
\hline 11 & GT-Transporte Coletivo e Cargas $\left(^{*}\right)$ \\
\hline 12 & GT-Logistica Regional $\left({ }^{*}\right)$ \\
\hline 13 & GT-Saneamento Ambiental $\left(^{*}\right)$ \\
\hline \multicolumn{2}{|c|}{ EE-4-DIVERSIFICAÇÃO E FORTALECIMENTO DAS CADEIAS PRODUTIVAS } \\
\hline 14 & GT-Turismo Regional $\left(^{*}\right)$ \\
\hline 15 & GT-Setor Automotivo \\
\hline 16 & GT-Setor Moveleiro $\left(^{*}\right)$ \\
\hline 17 & GT-Aumento da Competitividade das Cadeias produtivas do ABC \\
\hline 18 & GT-Setor Petroquimico/Plastico $\left(^{*}\right)$ \\
\hline \multicolumn{2}{|c|}{ EE-5-AMBIENTE URBANO DE QUALIDADE } \\
\hline 19 & GT-IRQVU $\left({ }^{*}\right)$ \\
\hline 20 & GT-Qualiurb $\left(^{*}\right)$ \\
\hline 21 & GT-Eixo Tamanduatei/Ferrovias \\
\hline 22 & GT-Divisas Intermunicipais \\
\hline \multicolumn{2}{|c|}{ EE-6-IDENTIDADE REGIONAL E ESTRUTURAS INSTITUCIONAIS } \\
\hline 23 & GT-Incentivos Seletivos \\
\hline 24 & GT-Precatorios \\
\hline \multicolumn{2}{|c|}{ EE-7-INCLUSÃO SOCIAL } \\
\hline 25 & GT-Segurança Publica \\
\hline 26 & GT-Saude $\left(^{*}\right)$ \\
\hline 27 & GT-Movimento Regional Criança Prioridade $1\left(^{*}\right)$ \\
\hline 28 & GT-Habitação ( $\left.{ }^{*}\right)$ \\
\hline 29 & GT-Gênero e Raça $\left(^{*}\right)$ \\
\hline 30 & GT-Pessoa com Deficiência $\left(^{*}\right)$ \\
\hline 31 & GT-Cidadania e Defesa do Consumidor \\
\hline 32 & GT-Segurança Alimentar e Nutricional $\left(^{*}\right)$ \\
\hline 33 & GT-Esporte e Lazer \\
\hline 34 & GT-Cultura Regional $\left(^{*}\right)$ \\
\hline \multicolumn{2}{|r|}{ SUBGRUPOS TEMÁTICOS } \\
\hline $\mathbf{N}^{\mathbf{0}}$ & NOMES \\
\hline \multicolumn{2}{|c|}{ EE-2-SUSTENTABILIDADE DE ÁREAS MANANCIAIS } \\
\hline 01 & SGT-Pesqueiros $\left({ }^{*}\right)$ \\
\hline 02 & SGT-APP em areas urbanas \\
\hline \multicolumn{2}{|c|}{ EE-4-DIVERSIFICAÇÃO E FORTALECIMENTO DAS CADEIAS PRODUTIVAS } \\
\hline 02 & SGT-Gestão em Tecnologia \\
\hline 03 & SGT-Polo de Moldes \\
\hline 04 & SGT-Desenvolvimento do Empresario Empreendedor \\
\hline 05 & SGT-Qualificação Profisional \\
\hline 06 & SGT-Credito e Financiamento/Setor Plastico \\
\hline \multicolumn{2}{|c|}{ EE-7-INCLUSÃO SOCIAL } \\
\hline 07 & SGT-Saude Mental $\left({ }^{*}\right)$ \\
\hline 08 & SGT-Guardas Municipais Femininas \\
\hline
\end{tabular}

Fonte: Consorcio Intermunicipal Grande ABC, 2004 


\section{Comissão Técnica das Instituições Oficiais de Memória do Grande ABC}

Museu de Santo André, Serviço de Memória e Acervo e Serviço de Patrimônio Histórico de São Bernardo do Campo, Fundação Pró-Memória de São Caetano do Sul, Centro de Memória de Diadema, Museu Barão de Mauá, Centro de Apoio Técnico ao Patrimônio e Museu de Ribeirão Pires, Gerência de Projetos Patrimoniais de Paranapiacaba.

\section{EM DEFESA DE UM SISTEMA MUNICIPAL DE ARQUIVOS}

Este documento resulta da preocupação com o estabelecimento de uma política de arquivos e a criação de um sistema de arquivos no âmbito das administrações municipais, já manifestada pela Comissão Técnica das Instituições de Memória do Grande ABC no documento de apresentação desta Comissão, encaminhado a todas as administrações públicas do Grande ABC (prefeitos, secretários de Educação e Cultura, diretores dos Departamentos de Cultura).

Temos clareza da importância desta questão no que diz respeito à gestão dos documentos públicos, à sua importância para a história e memória da administração pública e ao direito dos cidadãos a estas informações. Temos também clareza da gravidade da questão já que se trata do cumprimento de dispositivos legais: a Constituição de 1988, que em seu artigo 216, parágrafo $2^{\circ}$, estabelece, "Cabem à administração pública, na forma da lei, a gestão da documentação governamental e as providências para franquear sua consulta a quantos dela necessitem" e a Lei $n^{\circ} 8.159$, de 08/01/91 ${ }^{115}$, que determina:

- É dever do Poder Público a gestão documental e a proteção especial a documentos de arquivos, como instrumento de apoio à administração, à cultura, ao desenvolvimento científico e como elementos de prova e informação (Art. $1^{\circ}$ );

- Os documentos de valor permanente são inalienáveis e imprescritíveis (Art. 10);

\footnotetext{
${ }^{115}$ Anexo 1 - Integra da Lei ${ }^{\circ} 8.159$, de 08/01/1991
} 
- É assegurado o direito de acesso aos documentos públicos (Art. 22);

- Ficará sujeito à responsabilidade penal, civil e administrativa, na forma da legislação em vigor, aquele que desfigurar ou destruir documentos de valor permanente ou considerado de interesse público e social (Art. 25).

Além dessas preocupações, recentemente o Arquivo Nacional e o Arquivo do Estado de São Paulo encaminharam a todas as prefeituras do Estado de São Paulo um ofício reiterando a necessidade do cumprimento destas leis e um manual de subsídios para a implantação de um sistema de arquivos municipais. Estes documentos foram encaminhados em alguns municípios do Grande $A B C$ para as instituições ou serviços de memória e história locais.

Com exceção de Rio Grande da Serra (onde está prevista, mas não implantada), todos os municípios do Grande $A B C$ possuem instituições de história e memória: Museus, Serviços de Patrimônio, Centros de Documentação e de Memória. Embora alguns municípios já tenham projetos a respeito, até hoje nenhum deles possui um Arquivo Público Municipal e um Sistema Municipal de Arquivos. ${ }^{116}$ É importante esclarecer que as instituições de memória não têm como competência ou atribuição instituir o Sistema de Arquivos e coordenar a gestão documental de toda a Administração. Elas não substituem o Arquivo Público Municipal, ainda que todas elas se ocupem de documentos. Entretanto diferem quanto aos produtores desses documentos, à maneira como eles passam a fazer parte de seus acervos e seu tratamento e ainda quanto ao público a que servem.

Partindo do elemento comum a todas, o documento, podemos dizer que "documento é qualquer elemento gráfico, iconográfico, plástico ou fônico pelo qual o homem se expressa. É o livro, o artigo de revista ou jornal, o relatório, o processo, o dossiê, a correspondência, a legislação, a estampa, a tela, a escultura, a fotografia, o filme, o disco, a fita magnética, o objeto

\footnotetext{
${ }^{116}$ Anexo 2 - Texto "Tipologia das Instituições de Preservação Documental" (Tessitori, Viviane. Manual da Oficina "Como implantar Centros de Documentação", AESP/ARQ-SP, 2001)
} 
utilitário, etc...enfim, tudo o que seja produzido por razões funcionais, jurídicas, científicas, culturais ou artísticas pela atividade humana."117

Documentos de arquivo são aqueles que, produzidos e/ou recebidos por uma pessoa física ou jurídica, pública ou privada, no exercício de suas atividades, constituem elementos de prova ou de informação. Formam um conjunto orgânico, refletindo as atividades a que se vinculam, expressando os atos de seus produtores no exercício de suas funções. Assim a razão de sua origem ou a função pela qual são produzidos é que determina a sua condição de documento de arquivo e não a natureza do suporte ou formato.

Os documentos públicos são todos aqueles que, de qualquer suporte ou formato, são produzidos ou recebidos por um órgão governamental na condução de suas atividades. São também documentos públicos aqueles produzidos e/ou recebidos por instituições de caráter público e por entidades privadas responsáveis pela execução de serviços públicos.

Os conjuntos destes documentos naturalmente acumulados constituem os arquivos públicos. Em cada órgão governamental é armazenado um valioso patrimônio público: seus documentos, essenciais para o governo e os cidadãos aos quais serve. Tais documentos são primordiais para o planejamento, administração e controle das operações governamentais, e, por isto, refletem a condução das funções públicas. Contêm informações sobre a origem, desenvolvimento e execução de programas governamentais. Mostram a estrutura organizacional do Estado, seus modelos de procedimento e a maneira como o governo utiliza os recursos públicos. Tal como outros importantes recursos do Governo, seus documentos devem ser gerenciados para assegurar eficiência e economia.

Considera-se gestão de documentos o conjunto de procedimentos e operações técnicas referentes às atividades de produção, tramitação, uso, avaliação e arquivamento de documentos em "fase corrente" e "intermediária", visando a sua eliminação ou recolhimento para guarda na $3^{a}$

\footnotetext{
${ }^{117}$ Bellotto, Heloísa Liberalli. As fronteiras da Documentação. Cadernos FUNDAP, nº 8, abril/1984
} 
fase, "permanente". Estes procedimentos estão baseados na "teoria das três idades" ou "ciclo vital dos documentos", que estabelecem:

- Os arquivos de primeira idade ou correntes têm sob sua guarda documentos freqüentemente consultados e de uso exclusivo da fonte geradora, são vigentes, cumprem ainda as finalidades que motivaram a sua criação.

- Os arquivos de segunda idade ou intermediários têm sob sua guarda documentos de uso eventual pela administração que os produziu, devendo ser conservados em depósitos de armazenagem temporária, aguardando sua destinação final: eliminação ou recolhimento para guarda permanente.

- Os arquivos de terceira idade ou permanentes têm sob sua guarda documentos que já cumpriram as finalidades de sua criação, porém devem ser preservados em virtude de seu valor histórico, probatório e informativo para o Estado e o cidadão.

$\mathrm{Na}$ verdade a função de arquivar sempre esteve presente na Administração. Entretanto o que tem caracterizado os arquivos das administrações é a desvinculação entre as três idades, interrompendo o fluxo dos documentos e, conseqüentemente, impedindo sua plena utilização.

Por outro lado a complexidade crescente das administrações, provoca o aparecimento de uma imensa massa documental que se acumula sem critérios técnicos arquivísticos, geralmente em locais absolutamente inadequados: é o lamentavelmente conhecido "arquivo morto".

Acreditamos que apenas a instituição de um Sistema de Arquivos Públicos Municipais pode promover a eficiência na gestão da documentação pública, considerando toda a documentação produzida e todas as etapas de seu ciclo. O resultado será a simplificação, racionalização e otimização dos procedimentos, e o estabelecimento de critérios, prazos e responsabilidades através das Tabelas de Temporalidade ${ }^{118}$ para eliminação ou conservação

\footnotetext{
118 Tabela de Temporalidade é um instrumento básico para o gerenciamento da documentação e dos arquivos. Ela permite a distinção das informações essenciais das repetitivas ou supérfluas, o reaproveitamento dos espaços de armazenamento das unidades e do próprio arquivo. Garante a preservação e a recuperação das
} 
dos documentos. Permite também o acesso mais rápido e eficaz do governo às informações necessárias para a administração do patrimônio público, democratizando o acesso à informação quer dos "clientes internos", quer da população. Além disso, ao organizar e conservar os documentos de valor histórico, estes apenas uma parcela do conjunto documental, cria condições para que a sociedade exerça o seu direito à memória.

Naturalmente a instituição desse Sistema Municipal de Arquivos, abrangendo a documentação produzida por todas as suas secretarias, exige o estabelecimento de:

- dispositivos legais: normatização do Sistema de Arquivos, leis, decretos, regimentos.

- recursos materiais: instalações adequadas para a documentação nas fases intermediária e permanente.

- recursos humanos: profissionais habilitados (arquivistas e técnicos de arquivo) por formação e prática, capazes não só de cuidar do arranjo, descrição e manutenção dos arquivos, mas, também, de possuir uma compreensão bastante ampla do desenvolvimento e atuação da instituição a que se referem os documentos.

Entendemos, portanto, que não há mais como protelar esta ação. A modernização do conceito de Administração, quer pública, quer privada, impõe que a informação esteja disponível rapidamente e que os documentos administrativos sejam conservados e acessados de acordo com os preceitos técnicos e metodológicos da Arquivologia.

Por tudo o que foi exposto, esperamos tenha ficado claro que não estamos tratando apenas de uma parcela, mas sim da produção documental de toda a administração que tem uma organicidade que não pode ser rompida. E ainda que para a gestão destes documentos desde sua produção é necessário o estabelecimento de normas e diretrizes para todos os órgãos

informações cuja guarda decorra de exigência legal, seja de interesse da organização (informações gerenciais) e/ou apresente valor permanente (INOJOSA, Rose Marie. Tabelas de Temporalidade. In: A sistematização de Arquivos Públicos. Ed. Unicamp, 1991). 
da Administração Municipal. Daí entendermos que o estabelecimento do Sistema Municipal de Arquivos deve estar vinculado a Secretaria de Administração ou de Governo.

As vantagens do Sistema Municipal de Arquivos, muitas delas já enumeradas, são significativas: credibilidade, racionalização, eficiência e modernização administrativas, economia de tempo e de espaço, transparência, auto-conhecimento, direito à informação e respeito à legislação vigente.

A Comissão Técnica, em nome das instituições que a compõem, reafirma seu interesse no assunto e se coloca à disposição para aconselhamento técnico, fornecimento de subsídios e esclarecimentos que se fizerem necessários. 